\title{
Genes, Parents, and Assisted Reproductive Technologies: Mistakes, Sex, Race, \& Law $^{+}$
}

\author{
Leslie Bender ${ }^{*}$
}

+ (C) 2002, Leslie Bender. All rights reserved.

* Associate Dean and Professor of Law and Women's Studies, Syracuse University College of Law. My understandings about families and parenthood have been deepened by the newest additions to my family: S.N. Sangmpam, Nana Sang Bender and Alida Sang Bender. I am very blessed. My other children, Benjamin Saller and Rachael Saller Bender, and my son-in-law, Todd Nicodemus, continue to multiply my joy. My beloved husband, Peter A. Sandwall, who died of cancer in 1995, is ever present in my family. The wonder and love in my life today are a testament to the gifts he gave me during his all-too-short life.

I am grateful for the help from my research assistants, Mary Beth Williams, Syracuse University College of Law, Class of 2002, and Ilyssa Kaufman, Class of 2003, and the able assistance of my administrative assistant, Mary E. Ippolito. Rachel Winard, Columbia Law, Class of 2003, provided helpful commentary on this essay during the editorial process, triggering me to restructure part of my argument. Several of my friends and colleagues have generously read and critiqued earlier versions of this essay: Daan Braveman, Deborah Kenn, Sarah Ramsey, and S.N. Sangmpam. Sang has lived with these arguments for the two years that it took this essay to grow from conception to print and his insights and thoughtfulness are interwoven throughout. Paris Daskalakis, Class of 2001, helped me out by copying the record of the Perry-Rogers $v$. Fasano case when he was in New York City over a winter break. The law firm of Tantleff, Cohen \& Tantleff, P.C. helped my research by sending me copies of the briefs and complaints in this case. Syracuse University College of Law supported this work with a summer grant, and our outstanding faculty gave me thoughtful feedback when I presented the arguments at a workshop in April 2001. I also received helpful feedback from the LeMoyne College community when I presented these ideas as the 2002 Beatrice Robinson Memorial Lecture for Women's History Month. 


\section{Introduction}

A true story: Two infertile couples, Donna and Richard Fasano of Staten Island, N.Y., ${ }^{1}$ and Deborah Perry-Rogers and Robert Rogers of Teaneck, NJ., ${ }^{2}$ went to the In Vitro Fertility Center of New York, an IVF clinic in Manhattan, for treatment on the same day in April 1998. Both couples were engaged in in vitro fertilization procedures that created preembryos $^{3}$ ("test tube babies") with hopes of giving birth to their own babies. Due to a clinical error that caused a pre-embryo mix-up that day, ${ }^{4}$ Donna Fasano was mistakenly impregnated with at least one and possibly between 3 and 6 of the Rogerses' pre-embryos along with at least one of her and her husband's pre-embryos. ${ }^{5}$ Deborah Perry-Rogers was also implanted with pre-embryos on April 24, 1998, but all those pre-embryos were her and her husband's. ${ }^{6}$ Unfortunately, the Perry-Rogers' pregnancy did not "take."7 A few weeks later on May 28, 1998, after Donna Fasano

1 Perry-Rogers v. Fasano, 276 A.D.2d 67, 715 N.Y.S.2d 19 (N.Y. App. Div. $1^{\text {st }}$ Dept. 2000). Although the opinion mentions Donna's first name, it never identifies Mr. Fasano's first name. I gathered this other information first from newspaper articles and then from the record in the case. Michael Grunwald, In Vitro, in Error, and Now, in Court; White Mother Given Black Couple's Embryo Will Give One 'Twin' Back, WASH. Post, March 31, 1999, at A01, available in 1999 WL 2208496.

${ }^{2}$ I first discovered their hometown in Samuel Maull, Teaneck Parents Opposing 'Twin' Visits, REC. N. N.J., February 4, 2000, at A06, available in 2000 WL 14796459.

${ }^{3}$ These fertilized few cells can also be referred to as zygotes, pre-zygotes, or -embryos, but for conceptual clarity in this paper (rather than scientific accuracy), I will call them embryos and pre-embryos interchangeably.

${ }^{4}$ Both couples have filed malpractice claims against the clinic operator, Dr. Lillian Nash, and the embryologist, Dr. Michael Obasaju. Bob Groves, Lawyers Argue Over Visitation in Case of Misplaced Embryo, REC. N. N.J., June 10, 2000, at A03, available in $2000 \mathrm{WL}$ 15818246. The Appellate Division ruled that the Rogerses' malpractice lawsuit for emotional harm damages may continue despite the absence of physical injury. PerryRogers v. Obasaju, 282 A.D.2d 231, 723 N.Y.S.2d 28 (N.Y.A.D., $1^{\text {st }}$ Dep't., 2001); Fasano v. Nash, 282 A.D.2d 277, 723 N.Y.S.2d 181 (N.Y.A.D., $1^{\text {st }}$ Dep't 2001). The original action in Perry-Rogers v. Fasano was filed under the index number for the malpractice claim, Perry-Rogers v. Nash, (N.Y. Sup. Ct. 1999) (No. 601212/99).

${ }^{5}$ Complaint at IITII 47, 66, and 81, Perry-Rogers v. Fasano (N.Y. Sup. Ct. 1999) (No. 601212/99).

${ }^{6} \mathrm{Id}$. at $\llbracket 65$.

${ }^{7}$ The Rogerses' complaint against the clinic alleges that once the clinic realized the mistake 
knew she was pregnant with twins, the clinic notified both couples of the mistake. The Rogerses attempted to learn who had their pre-embryos, but they were unable to find out at that time. The Fasanos, on the other hand, did not take any affirmative steps to identify either of their fetus' genetic parents during Mrs. Fasano's pregnancy or for several months after the children's birth. ${ }^{8}$

On December 29, 1998, Mrs. Fasano gave birth to two male infants, one of whom is European-American like the Fasano couple and the other who is African-American, like the Rogerses. The Fasanos were content to raise both sons, whom they named Vincent and Joseph. However, when the Rogerses learned about the birth "by luck,"" they insisted on having genetic tests done. Those tests revealed that the African-American boy was their genetic child. ${ }^{10}$ The Rogerses immediately sued for a declaration of parentage and custody. They also renamed the boy Akeil Richard Rogers. When genetic tests revealed that Joseph/Akeil ${ }^{11}$ was the genetic child of the Rogerses, the Fasanos agreed to relinquish custody to the Rogerses, if the Rogerses would execute a written agreement granting them liberal visitation. The agreement, signed on April 29, 1999, gave the Rogerses custody, but contained a carefully delineated visitation schedule and provided for $\$ 200,000$ liquidated damages, if the Rogerses violated the visitation agreement. Pursuant to that agreement, on May 5, 1999, the Fasanos signed affidavits acknowledging that the Rogerses were Joseph/Akeil's genetic parents,

of implanting Donna Fasano with their embryos, the clinic personnel quickly got a second batch of pre-embryos together to implant in Deborah Perry-Rogers, but those pre-embryos were of lesser quality. Complaint at II 48, supra note 5.

${ }^{8}$ Brief for Appellant-Rogers at 3, Perry-Rogers v. Fasano, 276 A.D.2d 67 (N.Y. App. Div. 2000) (No. 601218/99) (citing Record on Appeal, at 50-51 and 107).

9 I assume this "luck" was either a breach of confidentiality by someone at the IVF clinic or their following up on media reports about a mother who gave birth to twins of different races. I have found no reports that explain how the Rogerses actually came to learn who gave birth to their genetic child.

${ }^{10}$ Genetic tests revealed that Joseph/Akeil was 99.97 percent certain the genetic child of Deborah Perry-Rogers and 99.96 per cent certain the genetic child of Robert Rogers. Complaint at II 60, supra note 5.

11 Throughout this article, I call the baby, Joseph/Akeil or Akeil/Joseph, so as not to privilege one set of parents by using solely their name for the boy. 
consenting to the entry of a final order of custody in the Rogerses' favor, and agreeing to change Joseph/Akeil's birth certificate. On May 10, 1999, when the baby was four and a half months old, the Fasanos turned the infant over to the Rogerses. The next day the Rogerses complied with the agreement by discontinuing with prejudice the action against the Fasanos (although they retained their action against the IVF clinic).

Had the story ended here, we probably could have agreed that the best was made of a bad situation. But two weeks later the Rogerses were back in court seeking a resolution that was different from the one to which the parties had agreed. On May 25, 1999, the Rogerses sued the Fasanos by petitioning the court for a declaratory judgment about Akeil/Joseph's parentage, seeking sole and exclusive custody, and making no mention of the visitation agreement that was signed. After several stages of legal wrangling and a full evidentiary hearing, the court issued a January 14, 2000 order allowing the Fasanos substantial visitation. It is from this order that the Rogerses appealed, seeking to void the visitation agreement entirely. The appeals court rendered the startling decision that the Fasanos had no standing to claim visitation rights to Joseph/Akeil; they had no parental right to even ask the court to enforce the visitation agreement. The troubling resolution of this case by an intermediate appellate court of New York prompted my reflections in this essay.

This essay explores some of the legal policy questions that arise when strangers' lives become inextricably linked because of assisted reproductive technologies (ARTs) ${ }^{12}$ gone awry. At the intersection of law,

${ }^{12}$ ARTs include artificial insemination by donor (AID or DI), in vitro fertilization (IVF), embryo transfer, cryopreserved (frozen) embryos and gametes, GIFT (gamete intrafallopian transfer), ZIFT (zygote intrafallopian transfer), PGD (preimplantation genetic diagnosis), ICSI (intracytoplasmic sperm injection), gestational and traditional surrogacy, genetic enhancement or engineering, cloning, and more. These technologies, as a group, go by several other nomenclatures, including new reproductive technologies and collaborative reproduction. For an excellent early bibliography on these technologies, see ABA Task Force on the Law of Reproduction and Genetic Technology (H. Joseph Gitlin, Lori B. Andrews, Phyllis G. Bossin, Lawrence H. Stotter, Stuart B. Walzer \& Bruce Lord Wilder), Section of Family Law, A Guide to Reproductive and Genetic Technologies: A Selected Bibliography of Medical and Legal Writing (American Bar Association 1990). The expanded use of these reproductive technologies is phenomenal. A study published in June 2000 noted that one in 80 births in Britain are "test-tube" babies. One in 80 Born in Britain is a Test-Tube Baby, Daily Telegraph (London), June 28, 2000, available in 2000 WL 23256967. 
medicine, technology, and ethics, cases arising out of mistakes with ARTs reveal more than just the frights of failed technologies and human error. Cases like that of the Rogerses against the Fasanos unveil race-biased and sex-biased assumptions that skew our legal analyses. At the heart of the problem are the revealed assumptions about the role that genetics and genetic relationships should play in defining legal parenthood. The tendency of courts to default to a "genetic essentialism" 13 when trying to unravel the complicated messes of maternity created by mistakes in ARTs is alarming.

Genetic essentialism asserts that our genes and our DNA are the essence, the core, the most important constituent part of who we are as human beings; therefore genetics should overpower any other factor when defining things like biological parenthood. Genetic essentialism reduces human beings to the contents of our cells. It ignores the ways our cells and environments interrelate, the ways our physiological system functions as a whole organism, and the ways our minds and hearts affect our being. Additionally, genetic essentialism renders all our ways of nurturing and being nurtured by one another for naught.

My aim in writing this essay is to challenge courts, lawyers, bioethicists and legal theorists to reject genetics as the ultimate tie-breaker in contests over legal maternity and legal parenthood. I argue that a genetics-based or genetic essentialist approach is sex-biased, because it discounts entirely the relational, nurturing, biological contributions to reproduction that only women make--gestation and birth. I also argue that a genetics-based approach can be race-biased because it relies only on physical/biological signifiers of race, rather than understandings of the compound socio-political, historical, legal, cultural and economic meanings of race.

When an ART mistake involves racial differences as the PerryRogers v. Fasano case does, a genetic essentialist approach or a simplistic race-matching approach to parenthood dangerously reduces the complexity of the race issues to seemingly unadorned biological facts. If it was not genetic essentialism that led the court to biological notions of race, then the court employed other hidden race-biased assumptions that ought to be

\footnotetext{
${ }^{13}$ Dorothy Nelkin \& M. Susan Lindee, The DNA Mystique: The Gene As A Cultural Icon 38-49 (W.H. Freeman \& Co., 1995).
} 
exposed to light and challenged. None of this bodes well for an appropriate legal analysis of parenthood for victims of ART mistakes, and yet an appropriate legal analysis is more ominously needed every day.

Desperation for children of their own led the Fasanos and the Rogerses to use assisted reproductive technologies to achieve their desired ends. ARTs, when successful, have enormous power to help couples create new life, but ARTs can exaggerate the pains of infertility when they are not successful. ${ }^{14}$ As with any other humanly designed and implemented technological fix, ARTs may have a third consequence: the problems associated with negligent or reckless errors, or even with intentional abuses. The magnitude of harm from this third consequence cannot be overstated. ${ }^{15}$

14،'In 1995, approximately 7.1 percent of the nation's married couples with wives of childbearing age were currently infertile, meaning that they had not conceived after at least twelve months of unprotected intercourse. Approximately 12.9 percent of married couples reported some form of impaired fecundity, i.e., problems in conceiving or carrying a pregnancy to term." New York State Task Force on Life and the Law, Assisted Reproductive Technologies: Analysis and Recommendations for Public Policy, Executive Summary, http://www.health.state.ny.us/nysdoh/taskfce/execsum.htm. The written report suggests that "the incidence of infertility is $10.5[\%]$ among married couples with non-Hispanic black women, roughly 1.5 times greater than among Hispanic or nonHispanic white women." See also American Society for Reproductive Medicine (ASRM), Fact Sheet: Infertility, at http://www.asrm.org/ Patients/faqs.html (reporting that over 6.1 million Americans suffer from infertility). Lisa C. Ikemoto, The In/Fertile, the Too Fertile, and the Dysfertile, 47 Hastings L.J. 1007 (1996)(examining the discursive use of the language of fertility and infertility and procreative technologies and their consequences for our understandings and laws about motherhood, race, gender, class, and sexuality).

Linda Lacey and Barbara Berg make powerful pleas for understanding the perspectives of infertile women and couples, and urge feminist scholars and writers on this subject not to discount their pain, needs and good faith. Linda J. Lacey, "O Wind, Remind Him That I Have No Child": Infertility and Feminist Jurisprudence, 5 М ICH. J. GENDER \& L. 163 (1998); Barbara J. Berg, Listening to the Voices of the Infertile, in ReProduction, Ethics \& THE LAW 80 (J. Callahan, ed., Indiana U. Press 1995). Berg additionally critiques the repeated media, scientific, and scholarly descriptions of infertile couples as "desperate." Though I hear and value her critique, the concept of desperation still seems apt in this case to me.

${ }^{15}$ In addition to any physical harms that arise from ART mistakes, the emotional distress is unimaginable. Because the genuineness of emotional distress claims arising in these circumstances is not in doubt, in the two medical malpractice cases brought by both couples against the IVF clinic physicians, the New York Appellate Division, First Department, was willing to permit an action for emotional distress even without proof of physical injury, a 
The Fasano and the Rogers families are victims of inexcusable negligence by an ART provider. Were this essay about the medical malpractice lawsuit against the IVF clinic, proof of negligence would be easy and the only challenging issue would be how to assess the appropriate damages. But, this essay is about the child, who his family is, and the assumptions that courts should or should not use when resolving these complicated messes. Who should have custody of Joseph/Akeil and why? Should visitation be granted to the other couple? Lower and intermediate appellate New York courts were asked and already answered these questions in Perry-Rogers v. Fasano. ${ }^{16}$ Leave for appeal to New York's highest court, the Court of Appeals, was filed in December 2000 and denied in May 2001. ${ }^{17}$ The New York Court of Appeals' failure to take up this important case and to right the terrible wrong done by the lower courts does not silence the issues presented.

This essay begins by situating the problem of ART mistakes within the problems that law faces in the bioethics arena, and then specifically critiques the reasoning and approach in the October 2000 decision by the New York Supreme Court, Appellate Division, First Department in the Perry-Rogers $v$. Fasano case. My critique illustrates that in order to judge this kind of dispute appropriately, courts must tackle deeper issues about the flawed assumptions underlying their analyses. Similar kinds of cases raising questions about genes, parenthood and assisted reproductive technologies will inevitably reach other state highest courts, even if the New York Court of Appeals avoided the issue this time around. My hope is to provide some insights that will enable courts and lawyers involved in cases of ART mistakes to understand the unintended biases that distort this decision-making process when they fail to examine their assumptions.

\section{Bioethical Dilemmas, ARTs, and Law}

highly unusual move for New York courts. Perry-Rogers v. Obasaju, 282 A.D.2d 231; 723 N.Y.S.2d 28 (N.Y. App. Div. 2001); Fasano v. Nash, 282 A.D.2d 277; 723 N.Y.S.2d 181 (N.Y. App. Div. 2001).

${ }^{16} 276$ A.D.2d 67, 715 N.Y.S.2d 19 (N.Y. App. Div. $1^{\text {st }}$ Dept. 2000).

${ }^{17}$ Perry-Rogers v. Fasano, 96 N.Y.2d 712, 754 N.E.2d 199 (N.Y. 2001). 
For the last two decades, our judicial system has trailed woefully behind (often being dragged kicking and screaming) the complex bioethical dilemmas that accompany the rapid advances in biotechnology, biomedicine, and assisted reproductive technologies. For a bioethics and law professor, the weekly news is an embarrassment of riches: conjoined twins for whom separation surgery necessarily will result in the death of one twin; ${ }^{18}$ "designer babies" whose embryos were genetically tested and

${ }^{18}$ See, e.g., In re A (Children) (Conjoined Twins: Surgical Separation), [2001] Fam. 147 CA, [2001] 2 W.L.R. 480 (C.A. September 22, 2000), available in 2000 WL 1274054. This British case involves Michaelangelo and Rina Attarc, a strict Roman Catholic Maltese couple originally from Gozo, who went to Manchester, England to give birth to their conjoined twins on August 8, 2000. Twins, Jodie and Mary, were joined at the abdomen with fused spines, two sets of legs and arms at right angles to their bodies, but one heart and one lung. Doctors said both would soon die if kept together because the heart and the other organs were not strong enough to support two bodies. Doctors said Mary had "primitive brain functions" and was "draining [the] lifeblood" out of Jodie. Id. at 204. The girls' parents refused separation surgery. Doctors went to court to get permission to operate. A British Court of Appeals ordered surgery after five days of hearings, in an order dated September 22, 2000, written by Lord Justice Alan Ward, himself the father of twin girls. Id. The judge said that Mary lived "on borrowed time, all of it borrowed from her sister. She is incapable of independent existence." Id. at 162. The court also said, "Jodie has a right to protest that Mary is killing her," describing the killing of Mary in this case as "legitimate self-defense" and "the lesser of the two evils- the death of one twin instead of the death of both." Id. at 204. See also Majorie Miller, British Judges OK Surgery to Separate Twins, L.A. Times, September 23, 2000, at A1; Warren Hoge, Siamese Twin is Separated; 'sadly dies' to save sister, N.Y. TIMES, November 8, 2000, at A9; and Editorial, A Cruel Solomonic Dilemma, S.F. Chron., September 6, 2000, at A20, available in 2000 WL 6490740. Surgery was performed when the girls were three months old on November 7, 2000. After the twenty-hour procedure in November, Mary died. At an inquest in December 2000, the Coroner, Leonard Gorodkin, did not find that the doctors or the hospital had committed a lawful act of homicide. Russell Jenkins, Siamese Twin Jodie is Bright and Flourishing, TIMES (London), December 16, 2000. Jodie has made remarkable progress in her recovery. Doc: Separating Twins a Tough Choice, NEWSDAY, December 30, 2000, at A20. Dr. Adrian Bianchi, one of the surgeons who operated on the twins, testified at the inquest that Jodie is "a bright, alert, and interested child whose neurological functions are in advance of her age." Life After Mary, STRAITs TimEs (Singapore), December 8, 2000 .

For a happier story of conjoined twins, Alaina and Xela Bryce, who were separated on October 31, 2000, see Steven Carter, Separated Twins Further Divided, The OrEgonian, November 28, 2000, at D01. Both children lived and are making good recoveries. Ken Olsen, Separated Twin Joins Her Sister at Home, The Columbian, December 29, 2000, at 
implanted to be tissue matches for living siblings; ${ }^{19}$ infertility clinic directors stealing or misplacing frozen embryos $;^{20}$ custody battles between divorcing

C1.

19 This process, called preimplantation genetic diagnosis (PGD), was most recently in the news for its use by a Colorado couple, Jack \& Lisa Nash. Their six-year old daughter Molly has Fanconi anemia, causing massive failure of bone marrow production, which, in turn, causes anemia, bleeding disorders, severe immune system problems and generally death from leukemia or other complications by age 7. Their newborn Adam was born in Denver on August 29, 2000 through PGD; he was selected to be disease free and a tissue match with his sister for bone marrow transplant from the umbilical cord. Rick Weiss, TestTube Baby Born to Save Ill Sister, WASH. Post, Oct. 3, 2000, at A01. The bone marrow transplant was performed on Sept. 26, 2000 and seems to have worked quite well. Molly has an 85-90 percent chance of being largely free of the marrow disease now. Peter Gorner, A Child is Born, and So Is a Genetic Dilemma, CHICAGo TrIB., October, 8, 2000, at C1. It took five rounds of PGD and IVF before Lisa became pregnant with Adam. Now three couples in Australia are "designing" babies to help their children with Fanconi anemia. Kelly Andrew, 'Designer' lifesavers last hope, mum says, The Christchurch Press, Dec. 26, 2001. See also, Annette Mccann, Designer baby bid to save boy's life; British couple say treatment offered in America could offer hope for son with leukemia, THE HERALD (Glasgow), October 16, 2001, at 12. Leah Wild, It took 10 people to make my babies, THE GuARDian (London), April 18, 2001, at 10.

${ }^{20}$ The most infamous case of misappropriated eggs and embryos is the 1994-1995 scandal at the University of California at Irvine Center for Reproductive Health. Whistleblowers exposed infertility doctors for taking eggs and selling them without the donors' consent and/or appropriating the eggs for research without the donors' consent. See Judith D. Fischer, Misappropriation of Human Eggs and Embryos and the Tort of Conversion: A Relational View, 32 LoY. L.A. L. REV. 381 (1999) (discussing the Irvine fertility cases); Rebecca S. Snyder, Reproductive Technology and Stolen Ova: Who is the Mother?, 16 Law \& INEQ. J. 289 (1998) (discussing the case of Loretta and Bacilli Jorge whose eggs were stolen at this clinic). Doctors Asch \& Balmaceda fled to Mexico and Chile respectively to avoid charges of theft and fertility-drug smuggling. Their colleague, Dr. Sergio Stone, served time for insurance fraud, and sued the University for failing to represent him in the litigation. Stone v. Regents of University of California, 77 Cal. App. $4^{\text {th }} 736,1999$ Cal. App. LEXIS 1138, (Cal. Ct. App. $4^{\text {th }}$ Dist. 1999). Charges were brought by many of the couples affected by the egg misappropriation. Approximately 120 cases were settled for over $\$ 21 \mathrm{~m}$. When U.C. Irvine closed this clinic, the 1,900 frozen embryos then stored at the lab were moved to California Cryobank, and approximately 300 couples were notified. At that time, another whistleblower leaked information about two dozen notebooks full of lab records that showed that embryos were stolen from as many as 500 patients and often sold on a black market to couples who implanted them in Brazil and South America. New 
or separated ex-partners over stored frozen embryos; ${ }^{21}$ posthumous reproduction; ${ }^{22}$ infertility treatment induced multiple births; ${ }^{23}$ defective,

suits have been filed based on the theft of those embryos, as opposed to the settled actions for the theft of the eggs. Kelly Felts-Gora filed suit in Santa Ana, California in 2000. See Aimee Welch, Special Report: When Scientists Kidnap Embryos, 16 Insight M AG., July 31, 2001 , at 20 .

In another recent debacle, Paul Fielding, an embryologist at North Hampshire Hospital and Infertility Clinic, disappeared after it was discovered that almost forty patients (39 couples) at two fertility clinics where he worked in Hampshire had their frozen embryos turn up missing. See Jenny Booth, et al., Baby mix-up scare after blunders at IVF Clinics, Sunday Telegraph (London), Sept. 24, 2000. Ironically, when his home was checked, there were still fresh floral tributes commemorating the recent birth of Benjamin, a second child to Fielding and his wife Alison, who also have a three-year old, Jonathan. With his rapid disappearance, suspicions have been raised about the genetic parentage of his new son. In August 2001, Fielding and another man were brought up on charges for this embryo loss. Jeevan Vasagar, Two appear before magistrates over disappearance of frozen embryos, The Guardian, August 3, 2001; Thomas Penny, Two face court over embryos scandal, Daily Telegraph (London), P15, August 3, 2001.

See also Rick Weiss, Babies in Limbo: Law Outpaced by Fertility Advances, WASH. Post, Feb. 8, 1998, at A1 (mentioning some cases of missing embryos against doctors and a fertility clinic in Rhode Island).

${ }^{21}$ See e.g., A.Z. v. B.Z., 725 N.E.2d 1051, 431 Mass. 150 (Mass. 2000); Kass v. Kass, 696 N.E.2d 174, 91 N.Y.2d 554 (N.Y. 1998); J.B. v. M.B., 170 N.J. 9, 783 A.2d 707 (N.J. 2001); Cahill v. Cahill, 757 So.2d 465 (Ala. Civ. App. 2000); In re Litowitz, 10 P.3d 1086 (Wash. Ct. App. 2000), reversed,146 Wash.2d 514, 48 P.3d 261 (WA 2002), amended, 2002 WL 31015235 (Wash. Sep 10, 2002)(No. 70413-9); and Davis v. Davis, 842 S.W.2d 588 (Tenn. 1992), cert. denied, 507 U.S. 911 (1993).

${ }^{22}$ Woodward v. Commissioner of Social Security, 2002 WL 4289 (MA 2002); In the Matter of the Estate of William J. Kolacy, 753 A.2d 1257, 332 N.J. Super. 593, (N.J. Super. Ct. Ch. Div. 2000); Hecht v. Superior Court, 50 Cal. App. $4^{\text {th }} 1289,59$ Cal.Rptr.2d 222 (Cal. App. 1996), rev. denied; Hall v. Fertility Institute of New Orleans, 647 So.2d 1348 (La. Ct. App. 1994). See also Michelle L. Brenwald \& Kay Redeker, A Primer on Posthumous Conception and Related Issues of Assisted Reproduction, 38 WASHBURN L.J. 599 (1999); Susan Kerr, Post-Mortem Sperm Procurement: Is it Legal?, 3 DePaul J. Health Care L. 39 (1999); Carson Strong, Ethical and Legal Aspects of Sperm Retrieval After Death or Persistent Vegetative State, 27 J. L. MED. \& ETHICs 347 (1999) and Gladys White, Commentary: Legal and Ethical Aspects of Sperm Retrieval, 27 J. L. MED. \& ETHICS 359 (1999); Jane Warren, Now I've Got My Son's Sperm, Nothing Will Stop Me Becoming a Gran, DAILy EXPRESS, September 20, 2000, available in 2000 WL 24216707; Rick Weiss, Babies in Limbo, supra note 10 (discussing Julie Garber); Helen Bruce, Baby-Battle: Parents Find Surrogate Mother, Birmingham Post (U.K.), December 27, 1999; Evelyn Shuster, The Posthumous Gift of Life: The World According to Kane, 15 J. ContemP. Health L. \& 
PoL'Y 401 (1999); Anne Reichman Schiff, Arising From the Dead: Challenges of Posthumous Procreation, 75 N.C. L. Rev. 901 (1997); John A. Robertson, Posthumous Reproduction, 69 IND. L.J. 1027 (1994). Britain struggled with the issue of posthumous reproduction in the case of Diane Blood. Mrs. Diane Blood sought to have a child using her dead husband's sperm. The Human Fertilisation and Embryology Authority in England had refused to allow her to use her dead husband's sperm, so she went to court to get permission, and then to Belgium for the IVF procedure. R v. Human Fertilisation and Embryology Authority, ex parte Blood, [1999] Fam. 151 [1997] 2 WLR 806 (C.A. 1997). She gave birth to a son, Liam, in 1998. In August 2000, the Government in England accepted a proposal that children conceived using fertility treatments and sperm from a dead man will be allowed to have their father's name recorded on their birth certificate, but there will be no extension of inheritance or succession rights to such children, and the father's name must be followed by the word "deceased." See Cherry Norton, At Last, Diane Blood can put the Name of her Husband on Son's Birth Certificate, The IndePEndent (London), August 25, 2000. Another woman, Marian Jordan will also be able to register her son Daniel as the child of her husband who died of cancer, but gave written consent to the posthumous reproduction. See id.

${ }^{23}$ Multiple births result both from infertility drug treatments and from the practice of transferring multiple embryos into a womb during each IVF cycle. See generally Ronald Chester, Double Trouble: Legal Solutions to the Medical Problems of Unconsented Sperm Harvesting and Drug-Induced Multiple Pregnancies, 44 ST. LoUIS U. L. J. 451 (2000); Mary Ann Davis Moriarity, Addressing In Vitro Fertilization and the Problem of Multiple Gestations, 18 St. Louis U. Pub. L. Rev. 503 (1999); Higher Order Multiple Births Drop for the First Time in a Decade, M2 PrEssWIRE (U.K.), April 18, 2001; and Doctors Warn of Boom in Multiple Births: Spurred by Technology, National Post (Canada), June 28, 2000, at A4, available in $2000 \mathrm{WL} 22982601$. The United States is the leader in multiple births from assisted reproductive technologies. Europe Is a Leader in Aiding Fertility by InVitro Means - Treatments in the U.S. Yield More Multiple Births, 28 WALL ST. J. EuR., June 29, 2000, available in 2000 WL-WSJE 21065156. In August 2001, the Human Embryology and Fertilization Authority in Britain issued new rules limiting the number of embryos that can be transferred to a womb during an IVF cycle with the goal of reducing the incidents of multiple births. David Derbyshire, Fertility clinics ordered to cut down on IVF multiple births, Daily Telegraph (London), August 8, 2001.

Recently, in a case of triplets from in vitro fertilization, a mother prevailed against the fertility experts based on the problems caused by the multiple births. Parents: Three's a Crowd, The Guardian (London), November 22, 2000. Fertility specialists are still developing drug treatment protocols that result in multiple births. It was reported in the fall of 2000 that two women were pregnant with twins and that another woman was pregnant with triplets after taking Viagra during IVF treatments. Danielle Demetriou, Childless Women Expecting Twins after Viagra Treatment, DAILY TELEGRAPH (London), 
contaminated or mistakenly donated gametes $;{ }^{24}$ the expanding commercial market in gametes (ova, sperm and pre-embryos); ${ }^{25}$ gestational and

October 23, 2000. They were among 10 women who have become pregnant using Viagra at the Assisted Reproduction and Gynaecology Centre in London. The drug was given to women who were told they were unable to conceive due to an extra-thin lining of the uterine wall. Viagra caused the wall to thicken and enabled the women to conceive.

${ }^{24}$ Johnson v. Superior Court, 95 Cal. Rptr.2d 864, 80 Cal. App. $4^{\text {th }} 1050$ (Cal. Ct. App. 2000), rev. denied, Supreme Court Minute 08-23-2000, 2000 Cal. LEXIS 6741 (Cal. 2000) (Parents and their minor daughter, who was conceived from donated sperm, sued sperm bank and its employees claiming that Ds failed to disclose that the sperm they sold came from a donor with a family history of autosomal dominant polycystic kidney disease (ADPKD). Parents sought an order compelling the donor's deposition and the production of records. The court of appeals held that the parents and child could compel the donor's deposition and production of documents to discover information relevant to their action.), pet. for writ of mandate denied, 2002 Cal. App. LEXIS 4580 (Cal.App.2d Dist., 2002); Harnicher v. University of Utah Medical Center, 962 P.2d 67, 1998 Utah LEXIS 57, 349 Utah Adv. 3 (1998, as corrected, March 19, 1999) (A couple went to fertility clinic exclusively seeking to find a way to have wife artificially inseminated by husband's sperm. To raise the likelihood of success the couple agreed to combine the husband's sperm with the sperm of an anonymous donor whom they selected because of his similar features to the husband. When their triplets were born, one of the triplet's coloring was extremely different from any one else in the family. Genetic tests revealed that the clinic had made a mistake and used the wrong donor sperm); Doe v. Irvine Scientific, 7 F. Supp.2d 737 (E.D.Va. 1998) (Frozen embryos stored in potentially contaminated albumin); Stiver v. Parker, 975 F.2d 261 ( $6^{\text {th }}$ Cir. 1992) (Contaminated gametes led to birth of disabled child). Another famous case of mistaken gametes is Michael and Elizabeth Higgins in Florida where Betty Higgins' eggs were fertilized with the wrong sperm (a European-American man), rather than her husband's (an African-American man.). This destroyed their marriage and Michael sued to make sure he was not liable for child support. Michael Lasalandra, Woman, Ex and Hospital Settle over Sperm Mix-up, Boston Herald, August 27, 1998. See also, Wilma and Willem Stuart, a Dutch couple who gave birth to one blond and one darker skinned child in 1995 due to a mix-up with some of the gametes used in IVF. Kenneth J. Ryan, M.D., National and International Responses to Ethical Issues in Assisted Reproductive Technologies, Assisted ReProd. Rev. 181, 184 (1996). Marlise Simons, Uproar Over Twins, and A Dutch Couple's Anguish, N.Y. Times, June 28, 1995, at A3. In a separate, infamous case, Dr. Cecil Jacobson, a fertility doctor, used his own sperm instead of the sperm of anonymous donors to inseminate approximately 120 patients. $\mathrm{He}$ was prosecuted by the government and eventually imprisoned. United States v. Jacobson, 785 F.Supp. 563 (E.D.Va. 1992) (Government action for protective order to close proceedings so parents of children allegedly fathered by Jacobson could testify without publicity). The most recently reported case of an IVF mix-up occurred in Britain in July, 2002, when a white couple gave birth to black twins. Sarah Lyall, Whites Have Black Twins in In-Vitro 
traditional surrogacy or contractual motherhood arrangements gone awry; ${ }^{26}$ intergenerational reproduction (e.g., grandmothers giving birth to their

Mix-Up, N.Y. Times, July 9, 2002, at A12.See also Judith D. Fischer, Misappropriation of Human Eggs and Embryos and the Tort of Conversion: A Relational View, 32 LoY. L.A. L. Rev. 381 (1999) (citing Teri Sforza, Who Rules How Babies are Made?, Orange County ReG., May 28, 1995, at A1); Fred Norton, Assisted Reproduction and the Frustration of Genetic Affinity: Interest, Injury and Damages, 74 N.Y.U. L. REv. 793 (1999) and Raizel Liebler, Are You My Parent? Are You My Child? The Role of Genetics and Race in Defining Relationships after Reproductive Technological Mistakes, 5 DePAul J. HeAlth CARE L. 15 (2002).

${ }^{25}$ Infertile Couple Offering \$100,000 to "Very Special Donor" with "Athletic Ability" to Donate Eggs, 4(10) Transplant News, February 29, 2000; Martha Frase-Blunt, OvaCompensating?, Washington Post F01, Dec. 4, 2001; Rebecca Mead, Eggs for Sale, 75 (22) The New Yorker, August 9, 1999; Rick Weiss, Limited Pay for Eggs Advised, WASH. Post, August 4, 2000, at A05. See also Ruth Macklin, What is Wrong with Commodification?, in New Ways of Making Babies: The Case of Egg Donation 106 (Cynthia B. Cohen, ed., Indiana U. Press, 1996); and Anne Reichman Schiff, Solomonic Decisions in Egg Donation: Unscrambling the Conundrum of Legal Maternity, 80 IowA L.REV. 265 (1995).

${ }^{26}$ Decker v. Decker, 2001 WL 1167475 (Ohio App. 3 Dist. 2001), appeal denied, Decker v. Decker, 94 Ohio St.3d 1411, 759 N.E.2d 787 (Ohio Dec 19, 2001) (TABLE, NO. 01-1850); In re Marriage of Buzzanca v. Buzzanca, 72 Cal. Rptr.2d 280, 61 Cal. App. $4^{\text {th }} 1410,77$ A.L.R.5 775 (Cal. Ct. App. 1998) (when father and mother split up in a gestational surrogacy case, father disclaimed all paternity); In re Moschetta, 30 Cal. Rptr.2d 893, 25 Cal. App. $4^{\text {th }} 1218$ (Cal. Ct. App. 1994); Johnson v. Calvert, 5 Cal. $4^{\text {th }} 84,851$ P.2d 776, 19 Cal. Rptr. 2d 494 (Cal. 1993), cert. denied, 510 U.S. 874, 114 S.Ct. 206 (1993) (gestational surrogate mother decided that she did not want to turn child over to contracting genetic parents); In re Baby M, 537 A.2d 1227 (N.J.. 1988) (traditional, genetic surrogate mother refused to give up child to genetic father and his wife); R.R. v. M.H., 426 Mass. 501, 689 N.E.2d 790 (Mass. 1998) (in dispute between father and surrogate mother, Massachusetts Supreme Court refused to enforce surrogacy agreement); Huddleston v. Infertility Center of America, Inc., 700 A.2d 453 (Pa. Sup. Ct. 1997) (surrogate mother sued when contracting father killed child); Stiver v. Parker, 975 F.2d 261 (6th Cir. 1992) (contracting father refused to take child after child contracted contagious infection that caused him to be seriously disabled); and Al Pessin, High Court Rules Separated Couple's Frozen Embryo May be Implanted, IsR. FAXX, September 27, 1996, available in 1996 WL 8153475 (Story of Danny and Ruti Nachmani, discussed more fully in Dalia Dorner, Human Reproduction: Reflections on the Nachmani Case, 35 Texas Int'L L. J. 1 (2000), where the Israeli Supreme Court, en banc, awarded the frozen embryos to the ex-wife, so she could have more children using a gestational surrogate). See also Doe v. Doe, 244 Conn. 403, 710 A.2d 1297 (1998) (child 
grandchildren or daughters giving birth to their siblings); ${ }^{27}$ post-menopausal pregnancies; ${ }^{28}$ implications of the Human Genome Project; ${ }^{29}$ genetic

born of surrogate mother and husband was not considered a "child of the marriage" when husband and wife divorced, although court had jurisdiction to decide the custody of child born through traditional surrogacy in divorce action between biological father and social mother.); Soos v. Superior Ct., 182 Ariz. 470, 897 P.2d 1356 (Ariz. Ct. App. 1994) (court found that genetic mother should be granted legal maternity instead of gestational mother). Problems in surrogacy cases continue to dominate the news. In 2001, we read about the story of Helen Beasley, who as a single mother in Britain became the paid surrogate for a California couple, but when it was determined that she would have twins, the couple ordered selective reduction and Beasley refused. The twins then became the subject of lawsuits. Another couple finally agreed to take the twins. Maria Belen-Moran, Another couple to take surrogate twins, 8/14/01 AssocPr On-line (No Page).

${ }^{27}$ Gordon Rayner, The Woman Who Gave Birth to Her Own Grandchild, DAILY M AIL (London), February 5, 2001; Charis Cussins, "Quit Sniveling, Cryobaby. We'll Work Out Which One is Your Mama!" in Cyborg Babies 44-66 (Davis-Floyd \& Dumit, eds., Routledge, 1998) (stories of sisters giving birth to their sister's children, i.e., their own nieces; mothers giving birth to their daughter's children, i.e., their own grandchildren; daughters giving birth to their mother's children, who are their genetic sisters); LEE M. Silver, Remaking Eden: How Genetic Engineering and Cloning Will Transform THE AMERICAN FAMILy 166-7 (Avon Books, 1998) (story of Karen Ferreira-Jorge and her mother Patricia Anthony in Johannesburg, where grandmother gave birth to her own granddaughter as "gift of love" to her daughter); and Simon Mowbray, Grandchild Surrogacy Set to Split Couple, Sunday Mercury (U.K.), June 11, 2000, available in 2000 WL 7303349.

${ }^{28}$ Seema Kamdar, Sixty-year-old woman gives birth to baby, THE TIMES OF INDIA, December 9, 2001; Rebecca Fowler, Baby's Bathtime Amid Rising Anger for IVF's Most Bizarre Family, Daily MaIL (London), June 23, 2001, at 16 (62 year old woman in France is surrogate mother to her brother's child with donor egg in order to inherit her mother's estate); John Phillips, Woman, 62, Gives Birth as 'Oldest Mother in World,' The Times (London), July 19, 1994 (Rosanna Della Corte, an Italian woman who is the oldest recorded mother to give birth, bore her son when she was 62); 51-Year-Old Chinese Woman Gives Birth to Test Tube Baby, Xinhua Gen. News Service, November 30, 2000. See also Mark V. Sauer, Richard J. Paulson and Rogerio A. Lobo, Reversing the Natural Decline in Human Fertility: An Extended Clinical Trial of Oocyte Donation in Women of Advanced Reproductive Age, 268 J.A.M.A. 1275 (1992); Guido de Wert, The Post-Menopause: Playground for Reproductive Technology? Some Ethical Reflections in THE FUTURE OF Human Reproduction (John Harris and Søren Holm, eds., Clarendon Press 1998); and William E. Schmidt, Birth to a 59-Year-Old Generates an Ethical Controversy in Britain, N.Y. TIMES, December 29, 1993, at A1.

${ }^{29}$ The Human Genome Project (HGP) is an international effort to map all the genes on the human genome. For overview of project, see National Human Genome Research Institute 
therapies ${ }^{30}$ or genetic engineering of embryos; ${ }^{31}$ sex-selection of children; ${ }^{32}$ chimera; stem cell research; and the cloning of animals and humans. ${ }^{33}$

(NHGRI), National Institutes of Health (NIH), The Human Genome Project, http://www.nhgri.nih.gov/HGP. See generally Symposium, Law and Human Genetics on the Threshold of the New Millennium, 49 Emory L.J. 745 (2000); Symposium, The Human Genome Project, 26 J.L. Med. \& Eтнісs 181-224 (1998); Francis S. Collins, Ari Patrinos, Elke Jordan and Aravinda Chakravarti, et. al., New goals for the U.S. human genome project: 1998-2003, 282 SCIENCE 682-689 (1998). One of the original researchers on that project, Craig Venter, broke away and started his own company, Celera Genomics, to complete the mapping sooner than anticipated by the HGP. See Dick Thomson, Craig Venter is a Man in a Hurry, TIME, January 11, 1999, at 49. A hot race pursued and in June 2000, President Clinton announced that both HGP and Celera had completed the project. Peter Gorner, DNA's Map Completed; How Genes Interact Still a Puzzle, CHICAGo TriB., June 27, 2000. In fact, they were then only near completion. Since that announcement, Celera has claimed that it has the entire genome mapped. Justin Gillis, Celera has Mouse Map Monopoly, WAsh. Post, April 27, 2001, at E01. Part of the funds (about 3\%) allocated for the Human Genome Project go to studying the Ethical, Legal and Social Implications (ELSI), because there are so many and they are so complex. See e.g., Justice and the Human Genome Project (Timothy F. Murphy and Marc A. Lappe, eds., U. Cal. Press 1994); Symposium, Genetics and the Law: The Ethical, Legal, and Social Implications of Genetic Technology and Biomedical Ethics, 3 U. CHI. L. SCH. Roundtable 417 (1996). See generally, The Code of Codes (Daniel J. Kevles and Leroy Hood, eds., Harvard U. Press 1992); The Human Genome Project and the Future of Health Care (Thomas H. Murray et al. eds., Indiana U. Press 1996); Robert Cook-Deegan, The Gene Wars: Science, Politics and the Human Genome, Part 5, at 231 (Norton \& Co. 1994). See also, Joan Stephenson, Ethics group drafts guidelines for control of genetic material and information, 279 J.A.M.A. 184 (1998) (discussing work of the Ethical, Legal and Social Issue Committee of the Human Genome Organization (HUGO)).

${ }^{30}$ The most prominent case of harm from gene therapy occurred when 18 year-old Jesse Gelsinger died four days after the therapy started. See Gene Therapy: Reports Disclose 691 Deaths and Illnesses, Am. Health Line, February 1, 2000; and Rick Weiss and Deborah Nelson, Penn Settles Gene Therapy Suit; University Pays Undisclosed Sum to Family of Teen who Died, WAsh. Post, November 3, 2000, at A04. See also Joshua Runyun, FDA Seeks to Disqualify Top U. Pennsylvania Gene Therapy Researcher, DAILY Pennsylvanian, December 13, 2000.

31 Alternatively called 'genetic enhancement,' genetic engineering to improve the characteristics of an individual is more than mere science fiction. See e.g., Alex Salkever, Building a Better Brain?, Christian SCIEnCE Monitor, September 2, 1999, at 1 (scientists alter mice genetics to increase intelligence). See also Symposium, Genetic Technology: Social Values and Personal Autonomy in the $21^{\text {st }}$ Century, 34 WAKe Forest L. REv. 561 
It is no wonder that the courts are befuddled by the conflicts that arise when these new technologies succeed and fail, whether of their own accord or because of human error. Legislatures, frequently unable or

(1999) (particularly articles by Michael Shapiro, Peter H. Huang, Maxwell J. Mehlman and Roberta M. Berry).

${ }^{32}$ Using pre-implantation genetic diagnosis for sex-selection, a Spanish couple has decided to bear only sons. James Meeks, Sons created to beat blood disease, GuARDIAN (London), October 17, 2000, at 6. The father of the children, who were born in May, suffers from hemophilia, which prevents blood clotting. Males do not pass the disease on to their children, but if they have a daughter, the daughter becomes a carrier. Doctors from the Universitat Autonoma de Barcelona made sure the embryos implanted in the mother's womb would grow only into boys. But, had the mother given birth to girls, they would have been perfectly healthy, just carriers for their further (hypothetical) grandchildren. If the mother is a hemophilia carrier undergoing IVF, she can have embryos tested before they are implanted and pick out any with hemophilia, something permitted in Britain, although sex selection to prevent a healthy daughter who may be a carrier is not permissible in Britain. This is the first case to be publicly written up in the Journal of Prenatal Diagnosis. Researcher, Josep Santalo, emphasized that they wouldn't genetically test a fetus once it was growing in the womb, but that this pre-implantation genetic diagnosis to prevent the transmission of abnormalities to descendants was not a problem. See also the case of Monique and Scott Collins, who used PGD at a Fairfax, Virginia IVF clinic to select a daughter embryo, giving rise to baby Jessica. Michael D. Lemonick, Designer Babies, 153 Time, January 11, 1999, at 64. See generally, Dorothy C. Wertz \& John C. Fletcher, Sex Selection through Prenatal Diagnosis: A Feminist Critique, in Feminist PerspeCtives IN Medical Ethics (Helen Bequaert Holmes and Laura M. Purdy, eds., Indiana U. Press 1992), at 240.

${ }^{33}$ James Chapman, Human clone trial hits ethical nerve, COURIER MAIL, November 27, 2001. An American couple is paying to clone their dead 10-month old child. See Jill Stark, Couple's Bid to recreate girl causes public outcry, SCOTTISH DAILY RECORD, January 3, 2001, available in 2001 WL 2779590; Philip Delves Broughton, We will clone dead baby girl, Daily Telegraph (London), January 3, 2001, available in 2001 WL 2905022. That quest, by Mark Hunt, a West Virginia lawyer, has ended, but a new candidate, a 59 year old single man with a terminal illness, is attempting to have the same group of scientists and fanatics, the Raelians, clone him. International Raelian Movement: Rael announces a new candidate for human cloning, 4/3/02 BIоTеCHWK 23, 2002 WL 9227896. See also Lori Valigra, Human Cloning Within Reach, Experts Say, United Press InT'L, January 5, 2001; and Cloning Human Beings: Report and Recommendations of the National Bioethics Advisory Commission (Executive Office of the President 1997) (Volumes $1 \&$ 2). The Executive Summary to that Report can also be found at 14 IssuEs L. \& MED. 217 (1998). See generally Lori B. Andrews, The Clone Age (Holt \& Co. 1999); Gregory E. Pence, Who's Afraid of Human Cloning? (Rowman \& Littlefield 1998); Clones And Clones (Martha Nussbaum and Cass Sunstein, eds., Norton \& Co. 1998). 
unwilling to articulate governing public policies ${ }^{34}$ leave the courts holding these "hot potatoes." Usually after a crisis involving assisted reproductive technologies or biotechnologies, commissions and task forces are formed to articulate guidelines for thinking about the issues and to develop proposals for legislative responses. ${ }^{35}$ Legislation that does get enacted often fails to anticipate the newest assisted reproductive technologies and their unique twists. ${ }^{36}$ The "victims" of this technology have no choice but to resort to the courts, and the courts have no choice but to find appropriate legal and factual analogies on which to base their decisions. When analogies fail, the courts must forge ahead, consistent with whatever policies can be discerned from prior legislative, judicial, and executive actions. ${ }^{37}$ But

34 As Larry Palmer argues about legislation and assisted reproductive technologies, "[L]egislation is difficult to pass in our process, and what emerges is not necessarily comprehensive. It usually takes some change in the political equilibrium for legislation to pass." Larry I. Palmer, Private Commissions, Assisted Reproduction, and Lawyering, 38 JURIMETRICS J. 223, 231 (1998) (book review).

${ }^{35}$ NY State Task Force on Life and the Law, Assisted Reproductive Technologies: Analysis and Recommendations For Public Policy (1998); National Advisory Board on Ethics in Reproduction (NABER), Report and Recommendations on Oocyte Donation, in New Ways of Making Babies: The Case of Egg Donation, at 233-302 (Cynthia B. Cohen ed., Indiana U. Press 1996); Assisted Reproductive Technologies and Genetic Committee of the ABA; Institute for Science, Law and Technology's Working Group on Reproductive Technologies (ISLAT), Art into Science: Regulation of Fertility Techniques, 281 SCIENCE, July 31, 1998, at 651-52; Royal Commission on New Reproductive Technologies, Proceed with Care (Canada Communications Group 1993); President's National Bioethics Advisory Commission, (last visited October 1, 2001) <http://bioethics.georgetown.edu/nbac>.

${ }^{36}$ See e.g., Unif. Parentage Act, 9B U.L.A. 301 (1987 \& Supp. 1999); Unif. Status of Children of Assisted Conception Act, 9B U.L.A. 135 (Supp. 1999).

${ }^{37}$ Recently, Judge Stanton of the N.J. Superior Court concluded that the general intent of N.J. law should override a literal interpretation as applied to new assisted reproductive technologies (in that case, posthumous reproduction), "when the legislature ...was not giving any thought whatever to the kind of problem we have in this case." In re Estate of Kolacy, 332 N.J. Super. 593, 753 A.2d 1257, 2000 N.J. Super LEXIS 275,* at *12. Judge Stanton notes, "We judges cannot simply put those problems on hold in the hope that some day (which may never come) the Legislature will deal with the problem in question. Simple justice requires us to do the best we can with the statutory law which is presently available." Id. Likewise, the Massachusetts Supreme Court permitted inheritance by posthumously conceived children in limited circumstances by looking at the general intent 
looking to policies and analogies is insufficient. Courts must proceed with sensitivity to justice concerns about gender, race, and class-based equality. Lawmaking in novel situations is a difficult task for courts, but certainly within their role. When heart-rending disputes such as that of the Fasanos and Rogerses appear in their courtrooms, judges cannot disregard their professional commitments to justice and equality just because the legislature has failed to act.

Courts fail us miserably when they use the language and procedures of technology-dated statutes to bar deep analysis of the substantive issues and justice concerns that arise in cases of ART mistakes. $^{38}$ But decisionmaking outside of a clear legislative context is also fraught with dangers. Judicial resolutions of disputes arising from the use of assisted reproductive technologies have often defaulted to a genetics-based approach to defining parenthood, which I argue, reproduces an unacceptable sex-bias in the law. In addition, in the interracial ART mistake cases like Perry-Rogers v. Fasano, courts may inadvertently utilize a race-matching approach that ultimately harkens

of the intestacy laws, but urged the Legislature to act. Woodward v. Commissioner of Social Security, 2002 WL 4289 (MA 2002)(“ As these technologies advance, the number of children they produce will continue to multiply. So, too, will the complex moral, legal, social, and ethical questions that surround their birth. The questions present in this case cry out for lengthy, careful examination outside the adversary process, which can only address the specific circumstances of each controversy that presents itself. They demand a comprehensive response reflecting the considered will of the people. In the absence of statutory directives, we have answered the certified question by identifying and harmonizing the important State interests implicated therein in a manner that advances the Legislature's over-all purposes.”)

${ }^{38}$ Contra Palmer, supra note 34, at 231 ("The real question is whether a court should abandon the legislative framework for resolving custody disputes in the context of divorce because assisted reproductive technology was used to produce the children. Whether the use of in vitro fertilization should make a difference in how the custody dispute is framed is a legislative rather than judicial decision," but when the legislature fails to act, the courts must intervene, at least to "provide an incentive for the parties and their lawyers to resolve the dispute themselves prior to a full litigated trial"). Palmer argues that courts are correct in reaching a result on a narrow ground and leaving the issue to the legislature, even recognizing that getting legislation on the subject is slow, plodding and difficult to achieve. "The best response from courts to cases that come before them is to resolve them narrowly, and on non-constitutional grounds, since legislatures rather than courts are the least detrimental legal means of changing the nature of family." Id. at 234. 
back to a kind of discredited biological racism. The Perry-Rogers $v$. Fasano case provides a concrete example for my more general arguments about the kinds of analyses that need to be explored in answering the bioethical and legal dilemmas that arise from ART mistakes. I use the case to illustrate both the horrors of ART mistakes and the ways in which courts unconsciously or subconsciously rely on deeply flawed and biased assumptions in determining parenthood. Part III critiques the Perry-Rogers $v$. Fasano decision to give a context to Part IV, which contains my deeper substantive critique of the issues about parenthood that arise from ART mistakes.

\section{The Perry-Rogers v. Fasano decision: A Critique of Flawed Reasoning}

The challenges of the Fasanos and Rogerses' story surpass any hypothetical problem that the most creative bioethics and law, family law, or torts professors could invent. One can not help but imagine the multiple ways in which thoughtful and creative answers could be formulated. The reasoning in the New York Supreme Court, Appellate Division, First Department decision was terribly disappointing. The Perry-Rogers $v$. Fasano decision ${ }^{39}$ turns on a standing issue, elevating process over analysis of the substantive issues. The court attempts to avoid all the sticky substantive issues by denying the Fasanos standing to seek visitation. This approach not only intentionally evades the issues that underlie the dispute, but deeply damages our emerging jurisprudence surrounding assisted reproductive technologies and impugns the court's perceived legitimacy.

No decisions seem more illegitimate than ones that deal with thorny and deep substantive issues, but are nevertheless resolved on subordinate, technical, procedural matters or literal readings of statutes that were never intended to cover such a situation. The Perry-Rogers $v$. Fasano decision of the New York Appellate Division fails for those reasons, in addition to its undeveloped theories of the case. Truthfully, I am not a process-phobe nor an advocate for rampant judicial activism. As much as the next person,

\footnotetext{
${ }^{39}$ Perry-Rogers v. Fasano, 276 A.D.2d 67, 715 N.Y.S.2d 19 (N.Y. App. Div. 2000).
} 
I respect that courts are supposed to "apply statutes" rather than "legislate." But when process concerns or crabbed readings of statutes prevail over reasoned resolutions of heart-wrenching conflicts, the judicial system becomes a mockery of justice. Form over substance deprives judicial opinions of legitimacy.

In Perry-Rogers v. Fasano, when the mother who bore the twins (Donna Fasano) sought to enforce a visitation agreement regarding the child who turned out to be genetically unrelated to her, but genetically related to the other couple (the Rogerses), she was told she did not have "standing" to dispute custody or visitation of the child. This resolution by the Appellate Division is worse than a substantive decision with a negative outcome. The court resolves the substantive issues by default, rather than by dealing with them directly, and it resolves the procedural issue in such a way as to block entirely one party's access to the judicial system for resolution of its dispute. Where one party is deprived of fair process and an opportunity to be heard, respect for and obedience to the law wanes. ${ }^{40}$ The Fasanos had no opportunity to present their claims about the best interests of the child and the quality of their relationship to him. Vincent, the twin who grew in the womb with Joseph/Akeil, was denied standing to seek visitation as a sibling. Where standing and courthouse "door-closing" is used as a flimsy excuse to avoid a reasoned explanation of the court's preferred substantive result, even more damage is done to public perceptions about the legitimacy of the judicial system. ${ }^{41}$ If, as an effect of the court's ruling, the Rogerses end up with exclusive custody of Joseph/Akeil and the Fasanos have no visitation rights at all, then the court has an obligation to tell us why that ought to be so and to explain the role of the ART mistake in the result.

\section{A. The Subject Matter Jurisdiction Arguments}

\footnotetext{
${ }^{40}$ See generally Tom R. Tyler \& John M. Darley, Building a Law-Abiding Society: Taking Public Views About Morality and the Legitimacy of Legal Authorities into Account When Formulating Substantive Law, 28 Hofstra L. Rev. 707 (2000); TOM R. Tyler, ET AL., Social Justice in a Diverse Society (Westview Press 1997); Tom R. Tyler, Why People Obey the Law (Yale U. Press 1990).

${ }^{41}$ For an analogous argument about the ways federal courts have used courthouse "door closing" mechanisms to avoid explaining their decisions on pressing substantive issues, see Daan Braveman, Protecting Constitutional Freedoms: A Role for Federal CourTs (Greenwood Press, 1989).
} 
In fairness to the court, the parties did not help the court reach the substantive issues in the case, because of the way they framed their arguments. They relied heavily on procedural arguments to make their cases for whether visitation should be allowed in this case. The appellate court could arguably claim that it was restricted—by the briefs and issues on appeal-to the approach it took in this difficult case. The Fasanos questioned the subject matter jurisdiction of the court based on the manner in which the Rogerses dismissed and then refiled their custody action under the same index number. The appeals court, in a unanimous opinion authored by David B. Saxe, ${ }^{42}$ dismisses this argument and issues a nunc pro tunc order to the Rogerses to get a new index number and to transfer the documents to that file. The court wisely rejects the Fasanos' argument that this procedural defect deprives the court of subject matter jurisdiction.

The Fasanos are not alone in trying to get the case dismissed on procedural grounds. The Rogerses also make procedural arguments about subject matter jurisdiction and standing. The court sensibly casts-off their subject matter jurisdiction argument as well. The Rogerses assert that the court has no subject matter jurisdiction and the Fasanos have no standing, because the Fasanos are "genetic strangers." The court denies this challenge to its subject matter jurisdiction stating that it has subject matter jurisdiction over all petitions for custody and visitation without regard to who the parties are. ${ }^{43}$ As the court sees it, the procedural problem in this case, if any, is not subject matter jurisdiction, but whether the Fasanos have standing to claim visitation rights.

\section{B. The Standing Arguments}

The court ultimately accepts the Rogerses' argument that the Fasano parents lack standing to claim visitation and that their son Vincent lacks standing, too. In finding no standing in the gestational parents or gestational womb-mate, the court insists that it does not reach its decision based "solely" on privileging genetics over other biological or social factors. The opinion specifically notes that, "it is simply inappropriate to render any

42 Other members of this court included Milton L. Williams, J.P., Peter Tom, Betty Weinberg Ellerin, and Richard T. Andrias.

${ }^{43}$ Perry-Rogers, 276 A.D.2d at 71. 
determination solely as a consequence of genetics." ${ }^{44}$ The court overtly rejects the idea that being a 'genetic stranger' deprives one of standing to sue for visitation. In an important move the court also hypothesizes that "a 'gestational mother' may possess enforceable rights under the law, despite her being a 'genetic stranger' to the child."

In Part IV of this essay I argue that the court did make this decision about standing "solely as a consequence of genetics", that is, on the basis of "genetic essentialism," 46 despite its protestations to the contrary, or else it made a decision "solely as a consequence of race." Furthermore, I suggest that genetic essentialism or genetic determinism serves as a cover for continued unconscious sexism in law and race-based decisions perpetuate biological racism in our society. Before I make those arguments however, I will finish reporting on and critiquing the court's other arguments leading to the denial of standing for the Fasanos.

The standing arguments are where the court seriously falters. The Rogerses make two major standing arguments, one of which the court aptly rejects, but the other of which the court adopts, despite its inconsistency with other reasoning within the opinion. First, the Rogerses claim that the Fasanos and their son Vincent do not have standing to argue for visitation, because they do not meet the statutory definition of parties who may seek visitation under New York law. ${ }^{47}$ Since the Fasanos gave up their rights as parents in the voluntarily signed agreement, and turned the baby over to the Rogerses, the Rogerses argue that the Fasanos no longer qualify as parents who have a statutory right to sue for visitation. The court discards this argument, noting in footnote 1 that it could conceivably treat both the genetic mother and the gestational mother as parents. ${ }^{48}$ Acknowledging

\footnotetext{
${ }^{44} I d$. at 73.

${ }^{45} I d$.

46 Dorothy Nelkin \& M. Susan Lindee, The DNA Mystique: The Gene As A Cultural ICON, supra $n .13$ at 38-49.

${ }^{47}$ N.Y. DOM. REL. LAW, $\$ 70$.

${ }^{48}$ Perry-Rogers, supra, at n. 1 states:
}

Despite the longstanding tradition that a child cannot have more than one mother and one father at a time, some exceptions to that firm rule have recently begun to develop. For instance, it is now possible for both parties in a lesbian couple to be a child's mother (see, Matter of Jacob, 86 N.Y.2d 651, 636 N.Y.S.2d 716, 660 N.E.2d 397). It is also possible for a parent to assert rights to continuing visitation despite 
another couple's genetic contribution to a child does not remove the birth parent's standing. ${ }^{49}$ So far, so good. It looks like now we can get to the substance of the dispute, right? Wrong.

The court unanimously decides that the Fasano parents and Vincent do not have standing to seek visitation after all, in response to the Rogerses' second standing argument. The Rogerses' deniatof-standing argument is based on the unique circumstances of this case. The court concludes that the Fasanos acted badly by not giving the child to the Rogerses at birth, since they were made aware of the embryo mix-up early in the pregnancy. The court reasons that because the Fasanos knew about the embryo mistake/mix-up early in the pregnancy, they could have "corrected" the problem as soon as the baby was born, rather than creating a situation where a parent-child bond has formed. The court is persuaded that the Fasanos behaved badly by allowing this bond to develop and therefore should be denied standing to raise visitation issues. In other words, they should be "punished" for their wrongdoing by barring their ability to maintain a relationship with their baby.

Within this parental standing argument are three separate, subordinate analyses, all of which are deeply flawed: an equitable "dirty hands"-like analysis, the application of faulty analogies, and inconsistent rhetoric surrounding maternal bonding. After denying the Fasanos standing as parents under any of its proposed analogies and muddying its argument by its rhetoric about intrauterine bonding, the court also summarily dismisses the womb-mate's "sibling" argument for standing. I will critique these arguments seriatim.

\section{Dirty Hands}

having given a child up for adoption (see, Social Services Law $\$ 383-c$; Matter of Gregory B., 74 N.Y.2d 77, 91, 544 N.Y.S.2d 535, 542 N.E.2d 1052). It is certainly conceivable that under some other circumstances, we would have to treat both genetic and gestational mother as parents, at least for certain purposes.

${ }^{49}$ Perry-Rogers, 276 A.D.2d at 74. 
At the end of the day, the court denies the Fasanos standing because of their "bad" conduct. Although the court does not use these words, this is arguably an equitable "dirty hands"-type argument. The Fasanos wrongfully permitted a bond to form when they kept the baby for over four months after its birth, so declares the court, therefore they now have the equivalent of "dirty hands." As Judge Saxe states:

[A]ny bonding on the part of Akeil to his gestational mother and her family was the direct result of the Fasanos' failure to take timely action upon being informed of the clinic's admitted error. Defendants cannot be permitted to purposefully act in such a[] way as to create a bond, and then rely upon it for their assertion of rights to which they would not otherwise be entitled. ${ }^{50}$

A party with "dirty hands" cannot expect a court to hear its claims. ${ }^{51}$

Denial of the Fasanos' right to argue for visitation seems an inappropriately strong punishment for forming abond with Joseph/Akeil. The court assumes that the Fasanos do not have any rights to the child ("rights to which they would not otherwise be entitled"), and, based on that assumption, concludes they acted purposefully and wrongfully by bonding with the Rogerses' baby. Yet, I argue infra, that the assumption of the Fasanos' non-parentage ${ }^{52}$ is contradicted by the court's own assertions in this opinion and by fair understandings of maternal parenthood. To my mind, it is indisputable that Donna Fasano is the child's gestational and biological mother, a relationship that does entitle her to rights to the child, or at a minimum, rights to make claims to the child. The court acknowledged as much in its first footnote, stating "It is also possible for a parent to assert rights to continuing visitation despite having given a child up for adoption. It

${ }^{50} I d$. at 76.

${ }^{51}$ As a principle of equity, the "clean hands doctrine" states that a litigant can be proscribed relief if s/he comes to court with "dirty hands" regarding issues to the dispute. 27A AM.JUR.2D EQUTTY § 126 (1996). Conduct constituting dirty hands includes unfair, dishonest, fraudulent, inequitable, or deceitful behavior.

${ }^{52}$ The court calls it Fasano's "nominal parenthood." Perry-Rogers v. Fasano, 276 A.D.2d at $74-5$. 
is certainly conceivable that under some circumstances, we would have to treat both genetic and gestational mother as parents[.]"53

However, even if we were to agree, for the purposes of argument, with the court's assumption that the Fasanos acted badly by not delivering the child to the Rogerses upon his birth, the Rogerses are not in a position to claim "dirty hands." Both sides to this dispute can be accused of "dirty hands," if we are to follow that logic. The Rogerses signed an agreement with the Fasanos that allowed visitation and promised to drop their lawsuit in exchange for physical custody of the child. Then after receiving physical custody of the child, they immediately violated the terms of the agreement. The law states that when both sides act with "dirty hands," neither may advance that equitable argument against the other. ${ }^{54}$ Nevertheless, the court excuses the Rogerses' "bad" conduct, ${ }^{55}$ and applies a "dirty hands"like rationale to bar the Fasanos from seeking visitation.

If the court were fairly utilizing equitable considerations, a more appropriate concept would be in pari delicto: "where the wrong of the one party equals that of the other, the defendant is in the stronger position. ${ }^{156}$ Since the Rogerses commenced this declaratory action for a declaration of their sole parentage and exclusive custody, the Fasanos are the defendants who benefit from this maxim. The court's failure to apply the more appropriate equitable approach confirms my conclusion that the court intended all along to find any way it could to give the child exclusively to the genetic parents. The power of the subterranean genetic essentialist ideology overrode traditional equitable considerations. And if it was not genetic essentialism that motivated this result, then the court was persuaded by a race-matching rationale that is equally, or even more, troublesome.

\footnotetext{
${ }^{53}$ Perry-Rogers v. Fasano, note 48, supra. (citations omitted)

54 27A AM.Jur.2D EQUITY § 126 (1996).

${ }^{55}$ Without explanation, the court apparently accepts the Rogerses' assertion that they were coerced into entering into the agreement for custody by the duress of not having another way to get physical custody of Akeil/Joseph.

56 27A Am. Jur.2D EQuiTy $\$ 132$ (1996). Both the clean hands doctrine and in pari delicto have been applied to custody, visitation and family law matters, although the court is supposed to yield to the dictates of justice and public policy if they conflict with application of the maxims.
} 


\section{Faulty Analogies}

The court's second logical error occurs in its use of faulty analogies. Judge Saxe recognizes the close analogy of this case's facts to gestational surrogacy cases, but he also tries to make (form?)analogies to cases where babies are switched at birth and to non-biological parent cases involving failed same-sex or step-parenting partnerships. None of these analogies is appropriate. More importantly, the analogy to gestational surrogacy upon which the court relies is most pernicious because there was no commercial or altruistic surrogacy agreement leading to the relationship between Donna Fasano and Joseph/Akeil. I shall address each analogy in the order that the court does.

\section{a. Switched babies}

For cases in which a switch or mix-up occurs at the hospital and new parents are given the wrong baby to take home, the court claims the law is clear. If the mix-up is discovered right away, there is no question in law that the matter should be corrected "at once." ${ }^{157}$ Like mix-up cases where the babies should be returned to their genetic parents immediately upon discovery of the mix-up, the court finds in this case that the Fasanos should have given the baby to the Rogerses immediately, thus preventing bond formation. The Fasanos may not argue for visitation based on a parent-child bond here, the court explains, when that bond was wrongly formed after learning of the mix-up. The court seems persuaded by the switched babies analogy.

[W]here the Rogerses' embryo was implanted in Donna Fasano by mistake, and where the Fasanos knew of the error not long after it occurred, the happenstance of the Fasanos' nominal parenthood over Akeil should have been treated as a mistake to be corrected as soon as possible, before the development of a parental relationship. It bears more similarity to a mix-up at the time of a hospital's discharge of two newborn infants, which should simply be corrected at once, than to one where a gestational mother

\footnotetext{
${ }^{57}$ Perry-Rogers, 276 A.D. $2 d$ at $74-75$ and fn. 2.
} 
has arguably the same rights to claim parentage as the genetic mother. $^{58}$

The apparent simplicity of this analogy to switched-babies cases is convoluted when one questions "when" the bond was wrongly formed. The court leaves us guessing on that score. Did the court criticize the Fasanos for forming a bond after the child's birth (during the time Joseph/Akeil lived with the Fasanos before he was transferred to the Rogerses) or for forming a bond during the remainder of the pregnancy (after the Fasanos were informed about the embryo mix-up and the possibility that one or both of their twins might be the genetic child of another)? This court never tells us what its understandings about parent-child bond formation are. At this point in the opinion, we do not know whether the court acknowledges intrauterine bonding or believes that all mother-child bonding occurs after birth.

Instead of explaining how it perceives parent-child bonding to work, the court concludes without explanation that the boy should have been turned over to the Rogerses immediately at birth. This mandated result is not obvious to me even now, and certainly it would not have been obvious to me as a parent at the time of the child's birth. I am perplexed about why this court is so sure that the baby should have gone to the Rogerses and that switched baby analogies are persuasive. The only way I have been able to make sense of the court's approach is to attribute it to an unspoken (and perhaps even unconscious) ideology of genetic essentialism that incorporates inequitable biases about gender, science and technology or to an unspoken (and perhaps even unconscious) ideology of racematching that is linked to biological racism. These arguments must be taken up later, though, because they interfere with the remainder of this critique of the 'switched-babies' analogy.

Assuming arguendo that the switched babies cases are correctly decided, ${ }^{59}$ this analogy still fails. Switched babies cases involve at least

${ }^{58} \mathrm{I} d$. at $74-5$ (footnote omitted).

59 The legal inspiration for the switched baby cases may itself be misguided. Turning over the mistakenly given baby, even in the switched baby cases, seems like a property-based or commodification argument. The baby becomes "property wrongly acquired." Yet, courts are loath to say that children are property or quasi-property, ownership of whom is to be 
two parents (often two sets of parents) each of whose baby is wrongfully taken and given to another. In this case, there is no mutuality of exchange based on the mix-up. It is not as though the Rogerses have the Fasanos' baby and the Fasanos have the Rogerses' baby. The hospital mix-up cases may come out the way they do, because once the mix-up is rectified, both sets of parents end up with the babies at the same time. In cases where there are not two children to be returned to their "rightful" parents when the switch is ameliorated (like this one) or where sufficient time has elapsed to allow the non-genetic parent(s) to form a familial bond, courts acknowledge, as the Perry-Rogers v. Fasano court does in footnote 2, that other courses of action may be followed. In those cases, the genetic parents may only get visitation rights, rather than legal custody, while the nurturing parents are entitled to continued custody. ${ }^{60}$ Because of the

determined by property law. See In re Baby M, 537 A.2d 1227, 109 N.J. 396 (N.J. Sup. Ct. 1988). See also Margaret Jane Radin, Market-Inalienability, 100 Harv. L .Rev. 1849 (1987) and Property and Personhood, 34 STAN. L. Rev. 957 (1982).

${ }^{60}$ Pope v. Moore, 261 Ga. 253, 403 S.E.2d 205 (Ga. 1991); Twigg v. Mays, 542 So.2d 241, 1989 Fla. App. LEXIS 1512 (Fla. Dist. Ct. App. 1989). Ilana Hurwitz notes another recent case of switched babies in her article, Collaborative Reproduction: Finding the Child in the Maze of Legal Motherhood, 33 ConN. L. REV. 127, 154-5 (2000), footnotes omitted:

Recently, in Virginia, Paula Johnson, who sought child support from her estranged boyfriend, discovered through blood tests that neither she nor her former boyfriend was the biological parent of Callie Johnson, the three-year-old little girl Paula had reared. After investigation, Paula Johnson discovered that a baby girl born to Kevin Chittum and Whitney Rogers, in the same hospital on the same day as she had given birth to a baby girl, actually was the child she was given to take home. Her biological daughter was mistakenly given by hospital personnel to Chittum and Rogers and raised by them as Rebecca Chittum. On the weekend after Paula Johnson's discovery, as fate would have it, Kevin Chittum and Whitney Rogers were killed in a car accident, leaving Rebecca Chittum orphaned of social parents and Callie Johnson orphaned of biological parents. Paula Johnson faced a dilemma. On the one hand she had an ineradicable biological connection to Rebecca Chittum. On the other hand, she had developed a mutual loving relationship with Callie Johnson, the child she nurtured and emotionally nourished for three years, the child for whom Paula had been "mother." Holding a large color photograph of Callie Johnson, Paula said about Callie at a news conference: "I love her wholeheartedly, with all my heart. . . . There isn't anything I wouldn't do for her." 
passage of time and bond that was formed, courts generally realize that there are interests more powerful than genetics that must govern the ultimate determination of parentage. Apparently the court in this case did not consider the bond formed during the more than seven months of pregnancy after the mix-up was discovered or the four and a half months after the child's birth as moving the Fasano claim into the latter category of analysis.

A second way the switched-babies analogy fails is that a baby and an embryo are not similar enough to be analogized. In the instant case, an embryo is what was mistakenly switched or misappropriated; there were no babies in existence at the time of the mix-up. To apply this mix-up analogy properly, Donna Fasano would have had to turn over the mixed-up embryo upon notification of the mistake. Could this really be what the court intends? Surely the court did not conclude that the embryo should have been removed from Fasano's womb and placed in Ms. Perry-Rogers', even if that were technologically possible without risk to both fetuses and both mothers. It is doubtful that the Rogerses would have even wanted that relief when they were notified of the clinic's mistake, particularly since Ms. Perry-Rogers' body had just endured the unsuccessful procedure from the month before. Besides, so far as the Rogerses' genetic embryo was concerned, it was already too late to do any transfer when the mix-up was discovered, because the embryo had become a fetus attached to Fasano by a placenta.

Realistically, the Rogerses can not be arguing that they wanted the embryo back at the time the error was discovered. That embryo no longer existed even then. Once the embryo implanted itself in Fasano's womb and grew to be a fetus, it was not the same being as the embryo mistakenly transferred, or even the same as the embryo would have been, had it been transferred into Perry-Rogers' womb in the first instance. The fetal environment powerfully affects the growth and development of the fetus. Government-sponsored warnings about pregnant women's cigarette smoking, drug use, and alcohol intake attest to the influence the fetal

When asked in a television interview if she had any intention of switching the two children, Paula answered unequivocally, "No." 
environment has on fetal development, as do government programs, like WIC, designed to supplement pregnant women's dietary needs. Actions of pregnant women affect the health and growth of their babies. By the time the embryo is gestated into a baby in another woman's womb, it is transformed from what was mixed-up in the first place. ${ }^{61}$ The gestating woman's contribution to what the embryo becomes is not excisable from the baby that is born. The switched-babies analogy just doesn't work.

\section{b. Same-sex couples' and stepparent custody disputes}

The court's second analogy is to custody and visitation disputes between same-sex parents or between stepparent and biological parent. In same-sex parents' custody disputes, the nurturing parent who is a "biological stranger" can be denied all rights to the child in New York. ${ }^{62}$ Likewise, the stepparent who has not legally adopted his or her stepchild, can be denied visitation based on being a "biological stranger."63 Using this analogy, the court follows what it calls the "strong policy considerations" applied in those "biological stranger" parent cases to find that the Fasanos have no rights to the child. Seeming to find this analogy superior to gestational surrogacy as well, ${ }^{65}$ the court relies on two New York cases, Alison $D .{ }^{66}$ and Ronald FF., ${ }^{67}$ that hold that "where a child is properly in the custody of parents, ... those parents are accorded a [sic] extremely broad rights to exclude any visitation, even by a person who raised and nurtured the child as his or her own."68 Though I believe those cases

${ }^{61}$ Hopefully, we will never go down the path of understanding the fetus/baby as an embryo with value-added.

${ }^{62}$ Matter of Alison D. v. Virginia M., 77 N.Y.2d 651, 569 N.Y.S.2d 586, 572 N.E.2d 27 (N.Y. 1991).

${ }^{63}$ Matter of Ronald FF. v. Cindy GG., 70 N.Y.2d 141, 517 N.Y.S.2d 932, 511 N.E.2d 75 (N.Y. 1987).

${ }^{64}$ The court discusses "strong policy considerations," but does not even explain what they are. Perry-Rogers, 276 A.D. $2 d$ at 75.

${ }^{65} \mathrm{Id}$.

${ }^{66}$ Matter of Alison D., supra note 60.

${ }^{67}$ Matter of Ronald FF. v. Cindy GG., supra note 61.

${ }^{68}$ Perry-Rogers, 276 A.D.2d at 75. See also Troxel v. Granville, 530 U.S. 57, 120 S.Ct. 2054 (2000). But see V.C. v. M.J.B., 163 N.J. 200 (2000), cert den.(N.J. Supreme Court granted visitation to the same sex partner who was a child's "psychological parent" using a best interests of the child standard.) 
are badly reasoned and wrongly decided, even assuming their legitimacy, their application to this situation is untenable.

Cases about stepparents or same-sex couples and their children's custody after the parenting couple splits up, i.e., cases in which one of the parenting adults is not biologically related to the children he or she nurtured, are inapposite to this case of a woman who has a clear biological connection to the child she carried in her womb for nine months. If biologicalrelatedness is the sine qua non of natural parenthood according to New York law, a gestational mother, such as Donna Fasano, necessarily meets that test. ${ }^{69}$ Her blood and nutrients course through the fetus. Her womb envelops and stretches to accommodate the fetus. The fetus is with the gestational mother every minute of every day, whatever she is doing, for nine months. These are basic physical, biological connections. Fasano has consistently asserted rights to the child based on her biological (gestational) motherhood. Fasano is the child's mother. So too may be Perry-Rogers, but that doesn't take away from Fasano's maternity and right to make claims for visitation. The court offers no explanation or reason that the "strong policy considerations" in the "biological stranger" cases should apply to this case, where the court acknowledges that it is inaccurate to call a gestational mother a "biological stranger." ${ }^{170}$ If nothing else, Fasano is clearly one of the child's mothers, the gestational mother, the woman who gestated the embryo to bring it to life. Without a "biological stranger" claim, application of the same-sex couples or stepparent analogy completely loses its force.

\section{c. Gestational surrogacy}

\footnotetext{
${ }^{69}$ We must distinguish between a gestational surrogate mother, one who for commercial or altruistic reasons agrees to bear a child for another woman, and a gestational mother, a woman who becomes pregnant and "gestates" a child, whether from her own genetic material or not, intending to be the child's mother. Surrogacy arguably adds another layer to the analysis of maternity that is not present in this case. See McDonald v. McDonald, 196 A.D.2d 7, 608 N.Y.S.2d 477 (N.Y. App. Div. 1994), at 12. But see Arrendondo v. Nodelman, 163 Misc.2d 757, 622 N.Y.S. 2d 181 (N.Y. Sup. Ct. 1994).

${ }^{70}$ Perry-Rogers, 276 A.D. $2 \mathrm{~d}$ at 75.
} 
The third erroneous analogy is to a gestational surrogacy case. This court makes a flawed assumption about maternity that is internally inconsistent within the opinion and just plain wrong. The court likens this case to gestational surrogacy. While Fasano may be the "gestational mother," ${ }^{71}$ she is not a "surrogate mother" or "gestational surrogate" in any of the ways that that term has been used. A gestational surrogate contracts or agrees to become impregnated with an embryo that is genetically unrelated to her. Regardless of whether courts decide gestational surrogate mother cases appropriately, ${ }^{72}$ their reasoning turns on the intention of the parties, as the Perry-Rogers v. Fasano court attests. $^{73}$ Based on intentions, this court finds that in a fictional custody dispute between the Rogerses and the Fasanos, the Rogerses would win:

Parenthetically, it is worth noting that even if the Fasanos had claimed the right to custody of the child, application of the "intent" analysis ...would-in our view-require that custody be awarded to the Rogerses. It was they who purposefully arranged for their genetic material to be taken and used in order to attempt to create their own child, whom they intended to rear. ${ }^{74}$

Frankly, I cannot understand how the court reached such an unexamined conclusion. Yes, the Rogerses "arranged for their genetic material to be taken and used in order to attempt to create their own child, whom they intended to rear." So did the Fasanos. Both couples engaged in the identical processes with identical intentions. Their intentions are not altered by the clinic's mistake. Each woman intended to bear a child of her own. Neither woman intended to bear a child for another woman or to have another woman bear her child, a fact that courts use to justify taking a child from its gestational mother in surrogacy cases. Were the intent-

\footnotetext{
${ }^{71}$ The court clearly identifies her as such in its opening paragraph, "This appeal concerns a tragic mix-up at a fertility clinic through which a woman became a "gestational mother" to another couple's embryo, when the embryo was mistakenly implanted into the wrong woman's uterus." Id. at 69.

${ }^{72}$ I would also argue that courts often err in their decisions and analysis in gestational surrogacy cases.

${ }^{73}$ Id. at 72-73 (citing Johnson v. Calvert, supra note 26 and McDonald v. McDonald, supra note 67$)$.

${ }^{74}$ Id. at 73 .
} 
based reasoning of the gestational surrogacy cases applicable at all, it would not lead to a preference of one set of parents over the other on these unique facts. For this reason alone, a gestational surrogacy analogy does not work.

Even more curious is why the court did not use an "embryo donation" analogy instead of a "gestational surrogacy" one. Embryo donation, which is akin to sperm or ova donation, may be the more appropriate theoretical approach, if we are to assume that something was "donated" (either a womb or a gamete/embryo) in this mix-up. ${ }^{75}$ The law has concretely addressed cases of sperm and ova donation. In those cases, the anonymous donor, though the genetic parent, is declared by law not to be the parent. ${ }^{76}$ The Perry-Rogers v. Fasano opinion contains no explanation for the court's preference of a gestational surrogacy analogy to an embryo donation one. The court's selection of a gestational surrogacy, rather than embryo donation, analogy reinforces my conclusion that the court's decision is rooted in unconscious or conscious assumptions of genetic essentialism. In truth, neither analogy works because neither situation represents the parties' intentions nor the facts of the case.

But more potent than the court's failure to consider an embryo donation analogy is the inapplicability of the gestational surrogacy analogy in the first place. As was noted above, being a gestational mother differs from being a gestational surrogate. The New York courts recognized how the different statuses require different results in McDonald $v$. McDonald. ${ }^{77}$ In McDonald, the gestational mother and her husband, both physicians, had used donated eggs from another woman (ostensibly the genetic mother), which they had fertilized with the husband's sperm. The resulting embryos were then transferred to the wife/gestational mother's womb, resulting in the birth of twins to the couple. When the couple later

\footnotetext{
${ }^{75}$ See e.g., Anne Reichman Schiff, Solomonic Decisions in Egg Donation: Unscrambling the Conundrum of Legal Maternity, 80 Iow A L. REv. 265 (1995).

76 Unif. Parentage Act $\S 702$, 9B U.L.A. 354 (2000); Unif Status of Children of Assisted Conception Act § 4(a), 9B U.L.A.___ (2000); and N.Y. Dom Rel Law $§ 73$. John C. Sheldon, a Maine judge, has recently proposed adaptations to these statutes. Surrogate Mothers, Gestational Carriers, and a Pragmatic Adaptation of the Uniform Parentage Act of 2000, 53 MaINE L REV. 523 (2001).

77196 A.D.2d 7, 608 N.Y.S.2d 477 (N.Y. App. Div. 1994).
} 
divorced, the husband sought sole legal custody of the twins, claiming to be the "only genetic and natural parent." In this "egg donation" case where the wife was the gestational mother, the court found that she was the natural mother and entitled to temporary custody, with permanent custody to be decided at a later hearing. Dr. Benita McDonald never intended to be a surrogate for another mother. The couple had intended to rear the children as their own. Likewise, Ms. Fasano had no intention of being a surrogate for another mother, and the Fasanos intended to rear the child as their own.

A gestational surrogate is always a gestational mother, but a gestational mother need not be a gestational surrogate. She may be gestating the embryo or ovum in order to call the child her own, as Dr. McDonald did. Applying the "intent" standard from McDonald, which the Perry-Rogers court discusses, would result in understanding this as an 'embryo donation' case. Following the reasoning of the McDonald precedent, Fasano would have standing to make a claim for visitation, and even custody, in the same way that Dr. McDonald did. The gestational surrogacy analogy is as flawed as the switched babies, same-sex or stepparents, and even egg donation, analogies. None of these analogies reflects the biological relationship present in the Fasano case.

The Appellate Division's decision is undercut by its use of faulty analogies to support Donna Fasano's lack of standing. If all the arguments by analogy are fatally flawed, then why were they convincing to the judges, and why did the court unanimously resolve the dispute the way it did.? I believe that the court was swayed by a subconscious, or conscious but unspoken, ideology that privileges genetics over all other forms of relationships. This genetic essentialism is especially pernicious because it reproduces gender biases, as I explain in Part IV.

\section{Inconsistent Rhetoric About Maternity and Bonding}

The key error, the one that logically and scientifically undermines the opinion, is the court's conflicting rhetoric about the bonds between a pregnant woman and her desired fetus. Judge Saxe uses blatantly inconsistent and contradictory reasoning in his analysis. Yet, the entire court unanimously agrees. 
A pregnant woman's maternal bonds with her child in utero are powerful. ${ }^{78}$ This bonding continues to increase during the pregnancy. ${ }^{79}$ As Ilana Hurwitz explains about the prenantal, mother-to-fetus bond, based on her extensive research:

Researchers have attempted to document particular incidents during pregnancy or behaviors of a pregnant woman that foster a bond between mother and fetus. Theorists have identified accelerated maternal attachment after sensory stimulation such as quickening, the mother's experience of fetal movement, maternal counting of fetal movements, and maternal viewing of early fetus by means of ultrasound imaging. Some researchers have pointed out associative behaviors with the unborn child that assist mothers to begin the attachment process, such as verbal communication, stomach rubbing, and visualizing what the baby will look like. Researchers have also identified factors that negatively impact maternalfetal attachment including depression and anxiety of the gestational mother, low levels of social support and high levels of control, domination and criticism from the mother's partner.

78 Ilana Hurwitz, Collaborative Reproduction: Finding the Child in the Maze of Legal Motherhood, 33 Conn. L. Rev. 127, 157-167 (2000); Scott B. Rae, Parental Rights and the Definition of Motherhood in Surrogate Motherhood, 3 S. CAL. REv. L. \& Women's STUD. 219, 245-246 (1994); R. Brian Oxman, Maternal-Fetal Relationships and Nongenetic Surrogates, 33 Jurimetrics J. 387, 424 (1993); Robin Fox, Reproduction And Succession: Studies in Anthropology, LAW And Society 71-79 (1993); John Lawrence Hill, What Does It Mean To Be A Parent? The Claims of Biology as a Basis for Parental Rights, 66 N.Y.U. L. Rev. 353, 397 (1991); Phyllis Chessler, SACred Bond: The LEGACY OF BABY M (1988).

${ }^{79}$ The process of bonding between a gestational mother and her fetus is called attachment. Carolyn Lerum, et al. The Relationship of Maternal Age, Quickening, and Physical Symptoms of Pregnancy to the Development of Maternal Fetal Attachment, 16 BIRTH 1, 13 (1989). Scientific and psychological evidence suggests that attachment begins early in pregnancy as a result of physiological and psychological changes to the gestating mother. Mecca A. Cranley, Development of a Tool for the Measurement of Maternal Attachment During Pregnancy, 30 Nursing Research 5, 281 (1981). 
One can draw evidence of prenatal bonding from the fact that women who suffer loss of pregnancy through miscarriage or elective termination of pregnancy for genetic reasons experience the grief of bereavement. Studies show that $71 \%$ to $75 \%$ of women who miscarry perceive the miscarriage as loss of a baby. Researchers have identified typical grief characteristics experienced by the mother after prenatal loss, including despair, anger, hostility, guilt, loss of control, rumination, depersonalization, somatic symptoms, and death anxiety. One can extrapolate from this evidence that pregnant women can, and many do, form bonds with their fetuses during pregnancy. ${ }^{80}$

The Perry-Rogers v. Fasano court acknowledges "that a bond may well develop between a gestational mother and the infant she carried, before, during and immediately after the birth." ${ }^{81}$ In addition, the signed agreement between both sets of parents acknowledged that bond and was recognized by the lower court. ${ }^{82}$ But when the opinion's rhetoric is analyzed, those declarations become mere lip service to the scholarship on point. ${ }^{83}$ The court immediately concludes that "the suggested existence of a bond is not enough under the present circumstances" ${ }^{184}$ to afford the

${ }^{80}$ Hurwitz, Collaborative Reproduction, supra note 78, at 159-160 (footnotes omitted).

${ }^{81}$ Perry-Rogers, 276 A.D.2d at 76.

${ }^{82} I d$.

83 The court cites Alice M. Noble-Allgire, Switched at the Fertility Clinic: Determining Maternal Rights When a Child is Born from Stolen or Misdelivered Genetic Material, 64 Mo. L. Rev. 517 (1999). For more scholarship on the maternal bond with fetuses/children in utero, see also Marie Ashe, Zig-Zag Stitching and the Seamless Web: Thought on 'Reproduction' and the Law, 13 Nova L. REv. 355 (1989); Marie Ashe, Law-Language of Maternity: Discourse Holding Nature in Contempt, 22 New ENG. L. ReV. 521 (1988); Vicki C. Jackson, Baby $M$ and the Question of Parenthood, 76 GEO. L.J. 1811, 1820 (1988); Barbara Katz Rothman, Recreating Motherhood: IDEOlogy and Technology in a PATRIARChAL SOCIETY (Norton 1989); Rebecca S. Snyder, Reproductive Technology and Stolen Ova: Who is the Mother?, 16 L. \& INEQ. J. 289 (1998); Note, Rethinking (M)otherhood: Feminist theory and State Regulation of Pregnancy, 103 HARV. L. REV. 1325 (1990); Feminism \& Bioethics: Beyond Reproduction (Susan M. Wolf, ed. Oxford U. Press 1996); Embodying Bioethics: Recent Feminist Advances (Laura M. Purdy and Anne Donchin, eds., Rowman \& Littlefield 1999).

${ }^{84}$ Perry-Rogers, 276 A.D.2d at 76. 
Fasanos standing as parents. Yet Alice Noble-Allgire, cited by the court, tells us:

[A] woman who mistakenly gestates someone else's embryo is likely to experience the same prenatal bonding as a surrogate mother and, therefore, suffer from the same psychological impact of relinquishing the child after birth. In fact, the impact may be even greater in the case of switched genetic material than in the voluntary surrogacy context because in the latter scenario, the surrogate mother entered into the arrangement with knowledge that she was carrying the child for someone else, [whereas in the case of switched embryos, the gestating mother believes she is gestating her own child. $]^{85}$

Despite referring to Noble-Allgire's scholarship, the court asserts that "any bonding on the part of Akeil to his gestational mother and her family was a direct result of the Fasanos' failure to take timely action upon being informed of the clinic's admitted error." ${ }^{186}$ The blatant contradictions in the rhetoric are unacknowledged.

Furthermore, the court suddenly ignores the mutuality of bond between pregnant woman and her fetus ${ }^{87}$ and how Donna Fasano became

${ }^{85}$ Noble-Allgire, supra note 79 , at 566 (bracketed material added to clarify the meaning of the quotation).

${ }^{86}$ Perry-Fasano, 276 A.D.2d at 76.

${ }^{87}$ The in utero bond is mutual in that the fetus bonds with the mother as the mother bonds with the fetus. A fetus feels the pregnant woman's every move; her every emotion releases hormones that affect the fetus. Fetuses hear their mother's voices and react to what their mothers eat and imbibe. Hurwitz, Collaborative Reproduction, supra n. 78, at 162-163 and notes, reports:

It is documented that a fetus is able to hear, sense, and learn prior to birth. It is also documented that children synchronize their biologic rhythms to the gestational mother. In addition, a mother's emotions and psychological experiences during pregnancy can affect a fetus in utero and after birth. Research results indicate that a mother's negative attitude toward pregnancy and her developing fetus can lead to emotional disturbance in her child. Researchers also assert that initial 
pregnant in the first place. Like the Rogerses, the Fasanos desperately desired to become parents. Like all couples engaged in assisted reproductive technologies, the Fasanos, no doubt, waited with bated breath to learn whether the pregnancy "took." Like other women who have achieved pregnancy after a difficult struggle, the excitement of the pregnancy promotes bonding with the fetuses immediately, even though the pregnant woman may realize she faces the dangers of loss from miscarriage.

We can only speculate that Donna Fasano reacted to her pregnancy in same ways that many other pregnant women do. First of all, Fasano was aware of her pregnancy before she was informed of the clinic error. She lived with the joy of having achieved this hard-won pregnancy day and night. Pregnancy is a twenty-four hour a day, seven days a week (24/7) condition. $^{88}$ She also probably lived with the fear of having a miscarriage. Second, although early in her pregnancy the clinic informed her that they made a mistake, all through her pregnancy she did not know for certain whether or not both babies were her genetic children. Of the embryos transferred to her womb, the other couple's embryo could have been one that didn't implant. Since more than one of her and her husband's

infant-mother attachment is at risk when a mother is prejudiced by her prenatal experiences of stress and by negative feelings about pregnancy and the developing child. (footnotes omitted).

Some of the scientific literature supports the idea that a fetus bonds with its mother in utero includes Madgy S. Mikhail, et al., The Effect of Fetal Movement Counting on Maternal Attachment to Fetus, 165 AM. J. OBstetrics \& Gynecology 988 (1991); and Byron England and Ellen A. Farber, Infant-Mother Attachment: Factors Related to its Development and Changes over Time, 55 CHILD Dev. 753 (1984).

${ }^{88}$ Hurwitz put it well when she described the physical contributions of a gestational mother:

[A gestational mother is] the one who may have to undergo the discomfort of nausea, exhaustion, water retention, varicose veins, bladder pressure, sleepless nights, physical distortion as the stomach swells, repeated medical check-ups and, ultimately, the pain of contractions and labor. Pregnancy is a constant state. There is no relief from the physical demands from the moment of conception until well after childbirth, when the body has had an opportunity to recover. The gestational mother's contribution in the procreative process is monumental.

Hurwitz, Collaborative Reproduction, supra note 78, at 158 (footnote omitted). 
embryos had been transplanted in addition to the Rogerses', she could have been carrying two of her own genetic children.

Third, surely the court did not mean that Fasano was obligated to avoid the in utero bond by identifying ${ }^{89}$ and selectively aborting ${ }^{90}$ the Rogerses' genetic embryo/fetus, with the consequent risk of miscarrying her own genetic fetus. (I imagine that the Rogerses would not have preferred that option, for that really is the Solomonic decision of killing the baby so the parents don't fight over it.) Finally, this pregnancy was something Fasano longed for. She had made physical and financial sacrifices in order to become pregnant. We ought not fault her for concluding that she was not going to "waste" the joy of the pregnancy by worrying about whether both fetuses were her genetic progeny and by consciously trying not to bond with them. I imagine that Donna Fasano

${ }^{89}$ Although she could have had amniocentesis, the record contains no evidence that she chose to do that. Amniocentesis creates a risk of miscarriage and/or damage to the fetus, so many mothers, even mothers with pregnancies that are "risky," choose not to undergo the procedure. In addition, in American jurisprudence, we now respect the autonomy of mothers to refuse to consent to intrusive procedures, even for the alleged benefit of the fetus they carry. See In re A.C., 573 A.2d 1235 (D.C. 1990) ). Rosamund Scott, Rights, Duties And the Body: Law and Ethics of the Maternal-Fetal Conflict (Portland, OR: Hart Publishing 2002). Amniocentesis in this case would not have been for the benefit of the fetus or the mother, but only for the benefit of third parties because a fourth or fifth party made an error. Here, the court seems to have wanted Fasano to do something, maybe something like amniocentesis during her pregnancy, for the benefit of another couple who are complete strangers. Courts generally will not override one party's autonomy for another's medical (or in this case, psychological) need, even in life-threatening situations and when they are relatives. See e.g., McFall v. Shimp, 10 Pa. D \& C.3d 90, 1978 Pa. D \& C. LEXIS 489 (Pa. Com. Pl. 1978). But see Strunk v. Strunk, 445 S.W.2d 145, 1969 Ky. LEXIS 151 (Ky. 1969) (where a court approved a mother's decision that her mentally disabled son, who was incapable of consent, donate one of his kidneys to his brother). No cases have ever required this kind of an intrusion for the benefit of a stranger.

${ }^{90}$ In cases of multiple simultaneous gestations, sometimes doctors recommend that women undergo a process of selective or elective reduction. Mary V. Rorty, Feminism and Elective Fetal Reduction, in Embodying Bioethics: Recent Feminist Advances (Donchin \& Purdy, eds., Rowman \& Littlefield, 1999), at 159. Rorty reports that many doctors refuse to reduce multifetal pregnancies when there are only twins, as in this case, but some doctors will reduce a twin pregnancy. She also cites studies that show a risk of loss of the entire gestation from the procedure. 
knew the fetuses were "hers" because she could feel them growing inside of her (regardless of genetics). ${ }^{91}$ When the growing babies moved or kicked in her belly, there was no way she could know which "one," if any, she was supposed to bond with and which one a court would punish her for bonding with. She had no clues about which baby's feet were getting under ribs or which baby made her uncomfortable every time she tried to lie on her side. It would be nearly impossible for a mother to chose to bond with one of two twins in utero but not with the other.

The court's understanding of Fasano's experience is terribly misguided. To ask Fasano, a woman who sought out assisted reproductive technologies and was willing to endure the consequent risk of a multiple birth resulting from use of the technologies, to decide not to form a bond with her fetuses because they may not be hers is unrealistic, unnatural and practically unthinkable (except that the appeals court thought it). And then, after having carried both babies for nine months, having bonded with them, and having gone through the labor and birth of both children, processes that further increase the bond, the court seems to conclude that Fasano should have given up one of her children after his birth.

Either there is an in utero bond that forms between mother and child, that the Fasanos cannot be "blamed" for acting badly in developing, or the in utero bond does not count at all. If an in utero bond between a pregnant woman and her desired fetus is a fact of nature in most cases, as the court recognizes that it is in its rhetoric and citations, Donna Fasano ought not be punished for forming it with her fetuses. The court contradicts the findings about the in utero bond it had just acknowledged in its text and footnotes, when it denies the Fasanos standing because they wrongly formed a bond with the child in utero. ${ }^{92}$

If the court respects and recognizes the in utero bond, then it still undermines its importance when the court implies that this maternatchild bond ought to evaporate at the child's birth, that is, when the child is $e x$ utero. In order to "punish" Donna Fasano (by denying her any rights to visit with Joseph/Akeil) for establishing the ex utero bond, the court must have concluded that regardless of the in utero bond, she should have

${ }^{91}$ Had she miscarried during the pregnancy, she would have grieved the loss of her two "babies," not one.

92 "Defendants cannot be permitted to purposefully act in such a[] way as to create a bond, and then rely upon it for their assertion of rights to which they would not otherwise be entitled." Perry-Rogers, 276 A.D.2d at 76. 
refused to continue a bond with the child she bore after its birth. This very unusual conclusion, especially in the absence of a prior contractual surrogacy agreement by a gestational mother to relinquish the child, requires further excavation of the court's probable underlying, sub silentio assumptions. The only way I can understand the court's reaching this conclusion is that there must have been something in the child's physical appearance that the court thought signaled to Fasano that she had to sever her relationship with this baby.

My logical conclusion is that the court faults Fasano for being a white woman who bonds with her dark-skinned child. Once she saw that the child she bore was African-American, according to the court, she was supposed to deny any natural bonds with it and give it away. One cannot help but wonder whether if Joseph/Akeil's racial physiognomy were "white" Fasano would have been required to give him away. The court made no such requirements about Vincent, even though he, too, could have been the product of an ART mistake.

In essence, the court is requiring Fasano to choose not to form bonds based on race. Donna Fasano's refusal to let race be a barrier to her bonding with the baby after his birth affected the court's determination that she has no standing to seek visitation. This seems terribly wrong on many levels and violates our core notions of fairness and justice. No doubt the court would say that it was not about color or race, but the fact that she knew one or more of her babies might be the genetic children of another couple. Yet the court does not speak of a legal duty of parents in all cases of ARTs (because such a mistake could always happen) to have their children genetically tested to determine parentage before ex utero bonds are formed. We do not require other mothers to get their children genetically tested before they bond with them. We have serious reasons to challenge this court's approach if, indeed, it is premised on the assumption that a white mother ought not bond with a child who appears to be AfricanAmerican.

The inconsistent rhetoric about maternal bonding in this opinion accentuates the flaws already noted in the Perry-Rogers v. Fasano appellate court decision. The sex-based and gender issues within this ART case blindside the court. Without openly addressing the gender issues which are so formidable in this case, the court is bound to get tongue-tied. It is essential to understand the science and culture of maternal bonding to reach a fair result in this complex dilemma. It is also essential to analyze 
the role that race plays in assessing the appropriateness of the ex utero bond between mother and child. I will take up more of the gender- and race-based issues that arise if the court defaults to a genetics-based analysis in the next section, but first I will complete my critique of the Appellate Division's decision in this case.

\section{In Utero 'Twin' as 'Genetic Stranger'}

Last, but not least, the Perry-Rogers court finds that Vincent, the Fasanos' genetic child, does not have standing as a sibling to claim visitation rights with Joseph/Akeil, because the statute defines a sibling as "related by whole or half-blood"93 and Vincent is neither. Although the court does not use this language, here the court is reprising the "genetic stranger" argument that it rejected in the case of the mother. Here, the genetic strangers are children who grew up together in the same womb at the same time. The court argues against the application of the "genetic stranger" category to Donna Fasano, but then applies it to Vincent's relationship to Joseph/Akeil. Fraternal twins are genetically different, but not considered less twins than identical twins who are genetically alike. They are twins because they grew together in the womb. They are not twins solely because they have the same parents. If having the same parents makes two children twins, then we would call brothers and sisters (all siblings) twins. We don't do that. In truth, there has never before been any doubt in the law that twins are siblings, even if the statute does not so define the term. The absence of this statutory definition may be due to the fact that the legislature assumed that it goes without saying that twins are siblings.

In addition, the statute speaks of "whole or half-blood," rather than of genetic relationships. Anthropologically and legally, prior to genetic testing, biological relationships or kinship relationships were defined through "blood lines." The legislature, referring to "blood" relations in the statute, was probably referring to these bological kinship relationships. But the concept and use of the term blood to represent biological kinship relations is especially interesting as applied to this case. A more complex meaning of blood as a metaphor or trope for kinship arises upon deeper examination. If being of the same "blood" is what constitutes kinship (rather than being of the same genes), Vincent and Joseph/Akeil are "blood brothers." The

\footnotetext{
${ }^{93}$ N.Y. DOM. REL. LAW $§ 71$.
} 
biology in this case is that both children were nurtured entirely by the same "blood" from Donna Fasano for nine months. They were wholly nurtured by her blood and it was her whole blood. Arguably this makes them of "whole blood" within the clear language of the statute. Nothing in the language "by whole or half blood" refers to genetics rather than nine months in one womb using the same blood for nourishment and oxygen. Surely this blood relationship should be enough to give Vincent standing to claim visitation. Instead, in the court's interpretation of the statute, it unwittingly falls back on assumptions that blood means genetics and genetics are the essence of a person. By applying these genetic essentialist assumptions, the court finds that the twins are strangers and not entitled to visit one another as brothers.

\section{The Deeper Substantive Issues in Perry-Rogers v. Fasano}

\section{A. Unanswered Questions}

What really is at issue in the Perry-Rogers v. Fasano case is the degree to which genetics ought to define parenthood in our era of assisted reproductive technologies. The Court makes false stabs at the issue, but ultimately only grazes it, instead, resting its decision on a shaky finding of no standing. Had it granted the Fasanos standing as parents (at a minimum, had it granted Donna Fasano standing as a mother), the court would have been required to decide the contested visitation claim based on a "best interests of the child" analysis, according to New York law. ${ }^{94}$ Since the parties reached an agreement about visitation that included a specific paragraph clearly acknowledging the importance of the child's continued relationship with the Fasanos, ${ }^{95}$ the court had a mutually agreed

\footnotetext{
${ }^{94}$ N.Y. Dom. REL. LAw $\$ 70$.

${ }^{95}$ The agreement stated:

All parties acknowledge that continued liberal visitation and contact between Joseph and Vincent and the Fasanos is in the best interests of Joseph. Deborah Perry-Rogers and Robert Rogers agree that they shall exert every reasonable effort to maintain reasonable access and contact between Joseph, Vincent and the Fasanos. All parties agree that they
} 
upon basis for determining Joseph/Akeil's best interests. This case was easier than it could have been if the parties had not already worked out the transfer of custody or visitation agreement.

The end result imposed by the court, with each set of parents ending up with one twin, suggests a Solomonic 'split-the-baby' decision, ${ }^{96}$ but unlike Solomon's story, in this case the 'split' ostensibly helps the parents, rather than kills the baby (although it "kills the twins"). But to look at this case as one about two children who are equally divided among two sets of parents distorts the analysis. This case is about one of the children only, about Joseph/Akeil. The parents had worked out a more Solomon-like decision than the court. In their visitation agreement, each set of parents got a piece of the child's time and affection, and the child got the benefit of both couples' love, time, and attention. In the court's resolution, the child is no longer "split" between the couples, but the child is also no longer the beneficiary of both families' attention and love. The child loses all connection to his birth parent and twin sibling, despite their ardent desire for further contact. The child's interests seem to have been subordinated to some grander principle, though that principle is not articulated. Paradoxically, Joseph/Akeil was deprived of his birth family and sibling in the easier case where the court only had to decide about visitation, not primary physical and legal custody, and the parties had negotiated a plan in advance.

The much more difficult case would have been a dispute over legal custody rather than just visitation. In that case the court would have had to face squarely whether it is in the best interests of a child to be placed with its genetic parents or its biological/social parents, when neither set of parents has been shown to be unfit. Since the appeals court did not see fit to order a "best interests" hearing in this case, I will proceed from the premise that each set of parents' home and home-lives were equivalent.

\footnotetext{
shall foster a feeling of affection between the children and each other. Deborah Perry-Rogers and Robert Rogers agree that they shall do nothing which may estrange Joseph from the Fasanos.

Reply Brief for Defendants-Respondents-Appellants (Fasanos) at 4, PerryRogers v. Fasano, 276 A.D.2d 67 (N.Y. App. Div. 2000) (No. 601218/99) (citing Record on Appeal, at 91-92).

${ }^{96}$ The Solomonic aspect of the case is that there were twins and the court splits the twins in two giving each couple one of the boys. While this may seem the most equitable solution at first blush, it raises very complicated issues about multiple births, ART mistakes, and infertility generally.
} 
The Appellate Division decision touches on some of the deeper issues and implications of the case in its standing analysis. In a footnote it acknowledges that in some cases both the gestational and genetic mothers may be parents for "certain purposes. ${ }^{97}$ In the text the Court indicates that it will not let genetics be its sole guide. ${ }^{98}$ It also refuses to estop the Fasanos from making claims based on their parenthood, merely because they acknowledged the Rogerses' as their child's genetic progenitors:

[The Fasanos' lack of standing was] not because we necessarily accept the broad premise that in any situation where a parent, possessed of that status by virtue of having borne and given birth to a child, acknowledges another couple's entitlement to the status of parent by virtue of their having provided the genetic materials that created the child, the birth parent automatically gives up all parental rights. ${ }^{99}$

One could easily be deceived into thinking that the court was about to make a just decision after carefully incorporating all the relevant concerns into its analysis. But that would, indeed, have been a deception.

The court's subconscious or silent preference for genetics over gestation prevails, regardless of any rhetoric it uses to the contrary. Finding no standing in the Fasanos was the same as finding that the Rogerses were the sole and appropriate parents. The genetic parents win completely. No other parents could even come before the court to argue for the legitimacy of their claims. Certainly the Court realized that its resolution foreclosed the Fasanos from visitation, and therefore foreclosed them from having any relationship with their child. As I suggested earlier, the injustice of this decision is compounded because the court makes this decision based on a procedural analysis rather than a substantive one.

\footnotetext{
97 "It is certainly conceivable that under some other circumstances, we would have to treat both genetic and gestational mothers a parents, at least for certain purposes." PerryRogers v. Fasano, supra note 1, at fn. 1.

98 "[I]t is simply inappropriate to render any determination solely as a consequence of genetics." Id. at 73 .

${ }^{99}$ Id. at 74.
} 
We need reasoned opinions on the substantive issues of this case. These issues include genetic essentialism, a gendered analysis of motherhood, and even more submerged issues of the role of race and class in family disputes arising from the use of ARTs. General issues about the reconceptualization of le gal parenthood in a post-ART age lurk large in this case. The court has an obligation to discuss what it means to have two legally recognized mothers, since it acknowledges the possibility, and why it completely forecloses that result in this case. The court has an obligation to explain why even though it acknowledges the bonds between a pregnant woman and her fetus, it ignores those bonds entirely in reaching its decision. If the court denies its reliance on biological determinism, or "genetic essentialism," but reaches a result only explainable by genetic ties, it needs to be explicit about its reasoning. ${ }^{100}$ In a complicated case like this one, the court shirks its responsibility when there is no serious analysis of the relationship between genetics and prenthood. At a minimum the court must explain why it preferred genetic evidence of family status over biological (gestational), cultural notions of family and kinship. This 'no standing' decision fails miserably in explaining its rationale and the result of completely cutting off the child from his birth family.

Additionally, there are open questions on ARTs and the relatively frequent multiple births that result from them. There is no more than a cursory discussion of the role ARTs play in creating new legal analyses, particularly with their risks of serious errors and the risks of multiple births in such delicate matters of creation and reproduction. Furthermore, the court misses the opportunity to discuss the appropriateness of applying the New York Domestic Relations law about standing to parties whose familial relationships were never conceived of ${ }^{101}$ by the legislatures that drafted the laws. ${ }^{102}$ Perhaps the court should assess whether reproduction has

\footnotetext{
100 For a discussion labeling the primacy of genetics in family relations as "genetic essentialism," see Dorothy Nelkin \& M. Susan Lindee, Genetic Essentialism Applied, in THE DNA Mystique: The Gene as a Cultural Icon (W.H. Freeman \& Co., 1995).

${ }^{101}$ All puns intended.

${ }^{102}$ See note 37, supra, for N.J. Superior Court Judge Stanton's assessment of this very issue in In re Estate of Kolacy, 332 N.J. Super. 593, 753 A.2d 1257, 2000 N.J. Super LEXIS 275 , (N.J. Super. Ct. Ch. 2000) at *12. Accord, Woodward v. Comm'r of Soc. Security, 2002 WL 4289, (MA 2002):

For the second time this term, we have been confronted with novel questions involving the rights of children born from assistive reproductive technologies. See Culliton v. Beth Israel Deaconess Med.
} 
become so commodified and market-based that contract or property law serve as better models for analysis than family law. Though family law makes the most sense because we are discussing parenting and familial relationships, ARTs inject such unusual dimensions into the relational dynamics of families that much of family law's reasoning fails to resolve these new dilemmas. Sometimes we suffer more from shoving these square pegs into round holes than from creating an entirely new receptacle that fits all the pieces.

Finally, courts need to determine how to proceed and who should bear the loss of a child when the tortious conduct of an ART provider harms two disparate, but equally innocent, parties. We need reasoned decisions from courts about whether tort law or family law or some new approach should inform us in these cases. Resolution of these issues is essential. A court's failure to look into these complex matters leaves future victims of ART mistakes doubly harmed. New victims, and we know it is inevitable that there will be new victims, will have to suffer the physical, emotional and life-altering consequences of the mistake, and then they will suffer by having to slog through this legal morass without any advice or guidance. The court was not justified in denuding this legal

Ctr., ante 285, 482 N.Y.S.2d 660 (2001). As these technologies advance, the number of children they produce will continue to multiply. So, too, will the complex moral, legal, social, and ethical questions that surround their birth. The questions present in this case cry out for lengthy, careful examination outside the adversary process, which can only address the specific circumstances of each controversy that presents itself. They demand a comprehensive response reflecting the considered will of the people.

In the absence of statutory directives, we have answered the certified question by identifying and harmonizing the important State interests implicated therein in a manner that advances the Legislature's over-all purposes. In so doing, we conclude that limited circumstances may exist, consistent with the mandates of our Legislature, in which posthumously conceived children may enjoy the inheritance rights of "issue" under our intestacy law. These limited circumstances exist where, as a threshold matter, the surviving parent or the child's other legal representative demonstrates a genetic relationship between the child and the decedent. 
dispute of all its underlying, substantive issues and only addressing formal procedural matters almost without regard to the peculiarities of the context.

In the rest of this essay, I offer a challenge to the Perry-Rogers v. Fasano court's and our culture's new bias in favor of genetics as a determinant of natural and legal motherhood. Recent cases, like Johnson v. Calvert, ${ }^{103}$ Belsito v. Clark, ${ }^{104}$ Soos v. Superior Ct., ${ }^{105}$ In the Interest of O.G.M., ${ }^{106}$ In the Marriage of Litowitz, ${ }^{107}$ Arrendondo by Arrendondo v. Nodelman, ${ }^{108}$ Culliton v. Beth Israel Deaconess Medical Center, ${ }^{109}$ and this Perry-Rogers $v$. Fasano case, seem to favor a genetics-based analysis of parenthood, despite at least one party's reasonable claim for a different approach. In this essay I urge courts to reject such an exclusive, geneticsbased analysis. In the next subsections, I will examine some of these issues that the court in Perry-Rogers v. Fasano ignored. First, I will discuss how a genetics-based definition of parenthood promotes an ideology of "genetic essentialism," and then assess how genetic essentialism masks the underlying issues of sex bias in this case. ${ }^{110}$ Alternatively, if the

\footnotetext{
${ }^{103}$ Johnson v. Calvert, 5 Cal. $4^{\text {th }} 84,851$ P.2d 776 (Cal. 1993).

${ }^{104}$ Belsito v. Clark, 67 Ohio Misc.2d 54, 644 N.E.2d 760 (Ohio C.P. 1994)

${ }^{105}$ Soos v. Superior Ct., 182 Ariz. 470, 897 P.2d 1356 (Ariz. Ct. App. 1994)

${ }^{106}$ In the Interest of O.G.M., 988 S.W.2d 473 (Tex. Ct. App. 1999), review dismissed (Jun 15, 2000).Do we need a parenthetical here?

${ }^{107}$ Litowitz v. Litowitz, 102 Wash. App. 934, 10 P.3d 1086 (Wash. Ct. App. 2000), reversed, 146 Wash.2d 514, 48 P.3d 261 (WA 2002), amended, 2002 WL 31015235 (Wash.Sep 10, 2002)(No. 70413-9).[Parenthetical? Does the way I use this case change in the later reversal or amendment?]

108 Arrendondo by Arrendondo v. Nodelman, 163 Misc.2d 757, 622 N.Y.S.2d 181 (N.Y. Sup. Ct. Queens 1994) (In action to amend children's birth certificate, the Supreme Court found that the woman who provided the egg, and hence the genes, in a gestational surrogacy case, was the mother, rather than the gestational surrogate).

109435 Mass. 285, 756 N.E.2d 1133 (2001)(Ordering that the genetics parents' names go on the birth certificate, rather than the surrogate mother's name, where "the gestational carrier agrees with the orders sought." Id. at 1138)

110 Socio-economic class also plays a powerful role in an genertics-based analysis of motherhood growing out of the use of ARTs. When conception and childbirth occur naturally, a genetics-based analysis of motherhood does not reflect class biases. Fertile couples, no matter what their economic status, can create pregnancies in which the genetic mother is the same person as the gestating mother, so that legal biological motherhood is not in dispute. However, where ARTs are utilized, a genetics-based analysis reveals deep classbased biases. Laurie Nsiah-Jefferson \& Elaine J. Hall, Reproductive Technology: Perspectives and Implications for Low-Income Women and Women of Color, in Healing
} 
court is not relying on genetic essentialism, then I argue that it necessarily was engaging in an unconscious, sub silentio race-based assessment of parenthood. The court's race-based assumptions may have skewed its decision and caused the unjust result in the case. The other matters raised in this subsection must be saved for another day.

\section{B. A Genetics-Based Analysis (or Genetic Essentialism)}

The court in Perry-Rogers v. Fasano clearly states that genetic ties are not the deciding factor in this case, and then, without even giving the

Technology: Feminist Perspectives 93 (Kathryn Strother Ratcliff, et. al., eds, Ann Arbor, University of Michigan Press, 1989); Dorothy Roberts, Killing the Black Body: Race, Reproduction, and the Meaning of Liberty (Pantheon Books, 1997). Whereas fertile women of any class can be gestating mothers, only infertile women with significant wealth can engage in the assisted reproductive technologies that allow one woman's ova or embryo to be transferred to another woman's womb. "In Massachusetts, where infertility care is mandated, the costs, with [ARTs] for a successful pregnancy is $\$ 39,375$, ... other estimates range from $\$ 60,000-\$ 800,000$, per successful pregnancy." Hazel Glenn Beh, Sex, Sexual Pleasure, and Reproduction: Health Insurers Don't Want You to do Those Nasty Things, 13 Wis. Women's L.J. 119, 173 n.362 (1998) (citations omitted), cited in Sherri A. Jason, Comment, "Loving Infertile Couple Seeks Woman Age 18-31 to Help Have Baby. \$6,500 Plus Expenses and a Gift”: Should We Regulate the Use of Assisted Reproductive Technologies by Older Women?”, 11 ALB. L.J. SCI. \& TECH. 287 (2001).

Even employed women with health insurance, clearly wealthier women than women without full-time jobs providing health insurance, may not be able to afford these technologies. Most health insurance plans exclude coverage for infertility treatment and assisted reproductive technologies. See e.g., Saks v. Franklin Covey, Co., 117 F.Supp.2d 318 (S.D.N.Y. 2000). Thomas D. Flanigan, Assisted Reproductive Technologies and Insurance under the Americans with Disabilities Act of 1990, 38 BRANDEIS L.J. 777 (2000); Shorge Sato, A Little Bit Disabled: Infertility and the Americans With Disabilities Act, 5 N.Y.U. J. Legis. \& Pub. Pol'y 189 (2001/2002). But see, Witcraft v. Sunstrand Health and Disability Group Benefit Plan, 420 N.W.2d 785, 788 (Iowa 1988) (where Iowa Supreme Court found that infertility was an illness covered by a health care plan). Only a few states mandate coverage for infertility treatments. See American Society for Reproductive Medicine, State Infertility Insurance Laws, http://www.asrm.org/Patients/insur.html (visited, Sept. 2002). At best, a small proportion of infertile women have adequate resources to purchase the assisted reproductive technologies that would allow them to have genetically related children by using other women's bodies. Despite the importance of classbased issues in ARTs, they are not the focus of this essay. 
Fasanos a chance to make their argument about gestational or biological motherhood, decides in favor of the genetic parents. The court is apparently so sure that the genetic mother should win that it is willing to reach that conclusion circuitously through a dubious-at-best "standing" analysis. Furthermore, the court precludes even visitation with the gestational mother without feeling the need to tackle the more complicated substantive issues raised above. The court's decision evidences its commitment to a simplistic, genetics-based analysis of legal and biological motherhood.

I argue that the better test of biological motherhood, if we must privilege one of a child's biological mothers in a contest between them, is to presume biological motherhood, and hence legal motherhood, based on the gestating and birthing of a child. ${ }^{111}$ The court finds differently by default. The court implicitly concludes that genetics is the better basis for biological and legal parenthood. Perhaps, in reaching this result, our culture's relatively recent addiction to science and technology overwhelmed our fundamental cultural understandings of motherhood that long preceded this addiction.

While science- and techno-philia clearly motivate part of the turn to genetics, there are more subtle motivations for this increasing reliance on genetics in law and culture, particularly in the realm of reproduction. Dorothy Nelkin and M. Susan Lindee analyze the way 'the gene' has become the new "sacred essence" of human beings in our culture. ${ }^{112}$ In their study of the cultural significance of the gene, they assert that the gene has become the equivalent of the "soul, assum[ing] a nearly spiritual importance as a powerful and sacred object through which human life and fate can be explained and understood. ${ }^{113}$ They illustrate how our cultural image of the gene has caused us to move from a primarily socialenvironmental analysis of human behavior to an individualized, geneticsbased analysis in many areas of our lives. We use DNA fingerprinting to

111 Of course, biological motherhood ought to be only one factor in determining legal motherhood. The best approach is to recognize multiple biological and legal mothers when multiple mothers create and care for the children.

${ }^{112}$ NELKIN \& LindeE, supra note 13, at Chapter 3.

${ }^{113}$ Id. at 57 . The gene is "an almost supernatural entity that has the power to define identity, determine human affairs, dictate human relationships, and explain social problems." Id. at 193. 
identify criminals or the remains of servicemen, ${ }^{114}$ and genetic testing to anticipate health problems in children and adults, to assess fitness for work, for risk assessment in insurance, to identify parents for purposes of support, custody and visitation, and to explain alcoholism, violent behavior and even extra marital affairs. Genetic analysis now expands to include behaviors and personality traits ${ }^{115}$ as well as physical states. ${ }^{116}$ This trend has more insidious effects than just limiting the opportunities of individuals. Nelkin and Lindee worry that "[g]enetic explanations of behavior and disease appear to locate social problems in the individual rather than in society....They are thus a convenient way to address troubling social issues." ${ }^{117}$ In some ways, the Perry-Rogers $v$. Fasano case follows suit by ultimately using genetics as a convenient way to address the troubling social issue of ARTs, identity, and human relations.

Biologica determinism, ${ }^{118}$ or "genetic essentialism," as Nelkin and Lindee call it, is the belief that the essence of a human being is his or her

${ }^{114}$ Mayfield v. Dalton, 901 F. Supp. 300 (D. Haw. 1995).

115 See e.g., Judith Rich Harris, The Nurture Assumption: Why Children Turn Out The Way They Do (Free Press 1998). A special thanks goes to Professor Sarah Ramsey for connecting this book to my research.

${ }^{116}$ NeLKIN \& LindeE, supra note 13, at Chapter 5.

${ }^{117}$ Id. at 194.

${ }^{118}$ Biological determinism is also called genetic determinism by some scholars. For some descriptions of these concepts, see Ruth Hubbard \& EliJah WALd, Exploding THE Gene M yth (Beacon Press 1993); Richard C. Lewontin, Steven Rose \& Leon J. Kamin, Not in Our Genes: Biology, Ideology, and Human Nature (Pantheon Books 1984) (arguing against biological determinism). Biological determinists conclude:

that human lives and actions are inevitable consequences of the biochemical properties of the cells that make up the individual; and these characteristics are uniquely determined by the constituents of the genes possessed by each individual. Ultimately, all human behavior hence all human society - is governed by a chain of determinants that runs from the gene to the individual to the sum of the behaviors of all individuals. The determinists would have it, then, that human nature is fixed by our genes...

What is more, biology, or "genetic inheritance," is always invoked as an expression of inevitability. What is biological is given by nature and proved by science. There can be no argument with biology, for it is unchangeable." $I d$. at 6. 
genetic code, the DNA. ${ }^{119}$ It is a belief that most of who we are is preprogrammed by our genetic codes, despite our environments or relationships or learning. Genetics, in this ideological approach, defines our family and our history and predicts our futures. Though not so named, genetic essentialism is what Aldous Huxley was satirizing and warning against in Brave New World. ${ }^{120}$ More recently, the film Gattica was designed to challenge genetic essentialism. ${ }^{121}$ Despite these poignant critiques, genetic essentialism continues to take hold as a dominant cultural ideology in society, according to Nelkin and Lindee.

Genetic information can assist us in treating illnesses and identifying bodies. Its usefulness in these areas, though, does not translate

In arguing against genetic determinism, Glenn McGee explains that, "Genetic determinism is the view which holds that everything . . . about human identity is determined at the moment of conception and encoded in DNA." Glenn McGee, The Perfect Baby: A Pragmatic Approach to Genetics 59 (Rowman \& Littlefield 1997). I will use the term genetic essentialism instead of biological determinism, but they represent the same ideology.

119 This ideology is called "gene-mania" by Allen Buchanan, Dan W. Brock, Norman Daniels and Daniel Winkler in From Chance to Choice 13 (Cambridge U. Press, 2000); "geneticization" by Mary Anne Bobinski, Genetics and Reproductive Decision Making, in The Human Genome Project and the Future of Health Care 79 (Murray, Rothstein \& Murray, eds., Indiana U. Press, 1996) at 107; and "genism" by George Annas, Genism, Racism, and the Prospect of Genetic Genocide, UNESCO $21^{\text {st }}$ Century Talks: The New Aspects of Racism in the Age of Globalization and the Gene Revolution at the World Conference against Racism, Racial Discrimination, Xenophobia and Related Intolerance, Durban, South Africa, September 3,2001, http://www.bumc.bu.edu/ www/sph/lw/pvl/genism.htm. Alta Charo discusses how reductionist it is to use a biological determinism or genetics approach. R. Alta Charo, Biological Determinism in Legal Decision Making: The Parent Trap, 3 Texas J. Women \& LaW 265, 269 (1994). ). Janet Dolgin examines how this ideology "reduces personhood to DNA molecules." Janet Dolgin, Personhood, Discrimination, and the New Genetics, 66 BrookLyn L.Rev. 755, 769 (2000-2001). Discrimination against people based on an ideology of genetic essentialism has been called "geneticism" by Abby Lippman, The Human Genome Initiative and the Impact of Genetic Testing and Screening Technologies: Article: Prenatal Genetic Testing and Screening: Constructing Needs and Reinforcing Inequities, 17 AM. J. L. \& MED. 15 (1991), at fn.16; Susan M. Wolf, Beyond "Genetic Discrimination:" Toward the Broader Harm of Geneticism, 23 J.L. Med. \& ETH. 345 (1995); and R. Alta Charo and Karen H. Rothenberg, "The Good Mother": The Limits of Reproductive Accountability and Genetic Choice, in Women and Prenatal Testing: Facing the Challenges of Genetic Technology (Ohio State U. Press 1994).

${ }^{120}$ Aldous Huxley, Brave New World (Doubleday, 1932).

${ }^{121}$ GatTiCA (Columbia Pictures 1997). 
into usefulness in determining legal parenthood. The use of genetics as the sole determinant of parenthood elides the biological with the social, cultural, legal and political. How families are constituted by law is not a scientific inquiry at all. Even if genetics tells us something about the science of human kinship relationships through the contents of individual cells, it certainly does not tell us all. On a purely scientific basis, it does not address the organism as an organized system or collection of systems, the organism's physiology, its interactions with the environment, its developmental growth, or its interrelationships with other organisms or beings. ${ }^{122}$ In terms of parenthood, genetics does not address the roles of pregnancy, labor, birth, and nurturance. And these are just the scientific or biological components that are absent from genetic essentialism. One of the gravest problems with genetic essentialism or genetic determinism is its reductionism. Genetic analysis cannot tell us anything about the social world, culture, politics, spirit or mind.

I am not arguing that genes are irrelevant to who we are, nor that the link between our genetic make-ups and some of our physical traits is not scientifically supportable, nor that our genetic constitution is independent of the characteristics we display. That there is a correlation between genes and some physical attributes or traits seems indisputable. The mapping of the human genome will certainly help fill in the gaps in our knowledge about the extent to which genes affect, influence and define us. ${ }^{123}$ But genetic essentialism claims more than correlations and addresses more than physical attributes. To genetic essentialists, genes cause and control us; they define who we are. 'Genes 'R Us.' Genetic essentialists argue that although some of the natural facts about genes are not optimistic ones, it is foolish to rail against them. Genetic diagnoses, genetic screening results, genetic definitions must be accepted. Science will not stop. If nothing else, it is pragmatic to join the bandwagon. Genetic therapies and enhancements are inevitable, so they say, as is human cloning, which may turn out to be the most extreme form of genetic essentialism.

\footnotetext{
122 Lenny Moss, What Genes Can't Do (Cambridge, MA: A Bradford Book, MIT Press, 2003) (advocating a developmental, interactive, organizational theory of biology, rather than a monadic cellular, gene-based understanding).

${ }^{123}$ See articles cited supra note 29.
} 
Nelkin and Lindee explain that genetic essentialism runs some serious risks. People may feel trapped by their genes, in ways that do not fairly represent their true potentials. Risks exist that genes will be seen as causes rather than correlations, as probabilities rather than as possibilities, as truths, rather than as predispositions.

The scientific concept of genetic predisposition assumes the existence of a biological condition signaling that an individual may suffer a future disease or behavioral aberration. But predisposition in the clinical sense is a statistical risk calculation, not a prediction. A person "predisposed" to cancer, for example, may have biological qualities that heighten the odds that he or she will develop cancer, in the same way that driving many miles each day heightens one's odds of involvement in an automobile accident. But many variables influence whether a person will actually suffer from cancer. Terms such as "predisposed" or "at risk" are understood by scientists to mean that the individual is vulnerable to a disease that may or may not be expressed in the future. In the quest to identify genetic predispositions, however, the statistically driven concept of correlation is often reduced to "cause." And possible future states, calculated by statistical methods, are often defined as equivalent to current status. ...[A]n individual "at risk" may be regarded as deserving differential treatment long before it is known whether or not the risk will materialize. ${ }^{124}$

There are risks that people will try to control the genetic codes of their children through preimplantation genetic diagnosis (PGD) ${ }^{125}$ and

\footnotetext{
${ }^{124}$ NELKIN \& LindeE, supra note 13, at 165-6.

${ }^{125}$ See Rich Weiss, Test-Tube Baby Born to Save Ill Sister, WASH. Post, October 3, 2000, at A01 for the story of Jack and Lisa Nash and the birth of their son, Adam, discussed supra note 19. See also James Meek, Sons created to beat blood disease, GUARDIAN (London), October 17, 2000, at 6 (Spanish couple where man has hemophilia used PGD to bear only sons who do not have the disease. Male children are the only ones subject to hemophilia; female children may be carriers, but are asymptomatic. This couple discarded all female embryos that may be carriers, even though the daughters would have been perfectly healthy themselves).
} 
genetic enhancement, ${ }^{126}$ thinking they can "design" their children. ${ }^{127}$ As with all technologies and sciences, we risk human error in reading genetic tests, in manipulating genes, and in understanding the interrelationships between one gene and another. There are also many other legitimate concerns about genetic essentialism: privacy, employment discrimination, health insurance, excuses or justifications for criminal conduct, and excuses or justifications for social and economic stratification, to name a few. In this essay, I am most concerned with what genetic essentialism does to our legal understandings of reproduction and families, and what it might say about sex and race. I save the other issues for another day.

\section{Gender-Bias Issues in a Genetics-Based Approach of Parenthood}

A genetics-based approach to legal familial rights will inevitably privilege men over women. In the first instance a genetic trump card to use in disputes over the custody of children created through ARTs does not seem sex-biased at all. Both women and men contribute equally when it comes to the genetic heritage of children. ${ }^{128}$ A man's genetic contribution to an embryo (one gamete called a sperm) is equal to a woman's genetic

${ }^{126}$ See e.g. Symposium, Genetic Technology: Social Values and Personal Autonomy in the $21^{\text {st }}$ Century, 34 Wake Forest L. Rev. 561 (1999).

${ }^{127}$ See e.g., Glenn McGee, The Perfect BABy, supra note 116, at Chapter 7 (arguing that genetic enhancement and "designed" babies are "not-so-deadly sins", but more akin to educational policies or other things parents do to help their children).

${ }^{128}$ At least this is true now. Speculation about children born of single-sex couples, either two mothers or two fathers and a surrogate mother, or asexual reproduction through cloning, abound. In these cases, the genetic contribution to the child can come from two women or two men, and the union can be manipulated by technicians in vitro. See e.g., LEE M. Silver, ReMAKING EDEN, supra note 27, at Chapter 15. A less technologically complicated means for two lesbians to have a biological child together is for one to donate the ova and for the other to gestate the embryo. But in these cases a donor sperm is required. See, e.g., Kyle C. Velte, Egging on Lesbian Maternity: The Legal Implications of Tri-Gametic In Vitro Fertilization, 7 AM. U. J. GENDER Soc. POL'Y \& L. 431 (1999); Anne Reichman Schiff, Solomonic Decisions in Egg Donation: Unscrambling the Conundrum of Legal Maternity, 80 Iowa L. REv. 265 (1995) (arguing that in those cases, both women should be legally recognized as mothers). 
contribution (one gamete called an ovum), so males would not be favored in a genetic contest between ovum and sperm gamete contributors. The dispute in the Perry-Rogers v. Fasano case was not about whether men should prevail over women in genetics-based parenthood controversies, so how could a genetics-based approach in that case reveal sex-bias? Deborah Perry-Rogers, the genetic mother, prevailed over Donna Fasano, the gestational mother, both of whom are women. If one woman can defeat another woman's claims when using a genetics-based approach to legal parenthood, how can a genetics-based analysis be male-biased?

The key to my argument is that whether conscious or unconscious, a genetics-based analysis of parenthood reinforces and replicates an understanding of reproduction rooted in a male experience. Because a male's only biological contribution to reproduction is his gene-carrying sperm, and because fathers are increasingly being identified by DNA genetic tests, courts may believe that parity requires that mothers be identified in the same way. ${ }^{129}$ If something like this reasoning is dictating results in these cases, even if it is below the surface rather than articulated, this false equality between male and female roles in reproduction exhibits a male-biased perspective. Women who are genetic parents benefit from this approach, but they only benefit, if they are "like men" with respect to their biological contributions in these ART cases $^{130}$ - if they are genetic contributors to the embryo. ${ }^{131}$ Women who are gestational mothers, that is, women whose contributions to reproduction include gestation, labor and birth, are not valued in a genetics-based analysis of parenthood. Geneticbased approaches to parenthood necessarily ignore one of the two ways

${ }^{129}$ See e.g., Soos v. Superior Court, 182 Ariz. 470, 897 P.2d 1356 (Ariz. Ct. App. 1994) (Court finds that, in a contest between genetic and gestational mothers, it violates equal protection not to let genetic mother prove her legal parenthood by DNA testing in the same way that men prove their legal parenthood).

${ }^{130}$ In fact, women are never really "like men" when it comes to biological reproduction. Although a genetic mother and a genetic father can be compared in their equal contributions of a single cell to the embryo, the biological intrusion necessary to take that single cell differs markedly. Even the genetic contributor woman has a stronger biological connection to the embryo than a genetic contributor man because of the intrusiveness of the process of gamete retrieval on the woman's body.

${ }^{131}$ Courts sometimes require that men and women participating in assisted reproductive technologies be both genetic contributors and intending parents. See e.g. Johnson v. Calvert, supra note 26; Litowitz v. Litowitz, supra note 102. The additional requirement of intention is not sex-biased and can be equally achieved by men and women. 
women can contribute to reproduction. Genetic definitions of parenthood value what only men can contribute to reproduction (gametic contribution) and do not value what only women can contribute (gestatational and birth contribution). Therefore, relying on genetics as the definition of parenthood, particularly of legal motherhood, is fundamentally sex-biased.

The privileging-of-genetics problem only becomes an issue between women when biological motherhood is bifurcated. ${ }^{132}$ Until the last few decades, a woman who bore a child was always also the woman who contributed half the genetic complement to that child. When an analysis of parenthood occurred, the law named the male party as a parent by his genetic contribution, i.e., his sperm causing the pregnancy, ${ }^{133}$ and the

${ }^{132}$ Since this discussion focuses on biological motherhood, it does not address arguments concerning other forms of mothering: social motherhood, step-motherhood, foster motherhood, adoptive motherhood, etc. The absence of these other forms of mothering in no way implies their lack of significance. The rights and interests of these social mothers are already recognized in law, even if not adequately, whereas the simultaneous or prioritized rights of more than one biological mother is an open question. The theory of genetic essentialism, which I challenge here, would devalue these social mothers if it were applied in their custody disputes over infants, just as it devalues non-genetic, gestating mothers.

A biological essentialism, as opposed to genetic essentialism, could also undermine social mothers, if misunderstood. If properly understood, however, there are significant analogies between a biological essentialist notion of motherhood and a social mothering notion of motherhood. Both biological and social mothering are about dependencies and relationships. A biological essentialism based on pregnancy, hbor and giving birth, recognizes that women's biological contributions to their fetuses/children are relational. Pregnancy is an active relationship between a pregnant woman and her fetus, JANICE G. Raymond, Women as Wombs: Reproductive Technologies and the Battle Over WoMEN's FreEdom 36-39 (HarperSanFrancisco, 1993), just as social mothering is an active relationship between mother and child. Genetic contributions, on the other hand, are about DNA and cells, at best about potential relationships, but not about active current relationships.

${ }^{133}$ For the moment, this excludes the legal presumption that the husband of a pregnant woman is the father. See, e.g., Michael H. v. Gerald D., 491 U.S. 110 (1989); In re Raphael P., 118 Cal. Rptr.2d 610 (Cal. App., 1 Dist. 2002). See also full discussion of legal presumption and its implications for legal parenthood in Janet L. Dolgin, Just a Gene: Judicial Assumptions About Parenthood, 40 U.C.L.A. L. ReV. 637 (1993). But see Rafferty v. Perkins, 757 So.2d 992 (Miss. 2000) (S.Ct. of Mississippi rejected the presumption that 
female party as a parent by her giving birth (which also coincided with her ovum creating the child). 'Bearing a child' was a synonym for 'being the child's genetic mother. ${ }^{134}$ The new reproductive technologies have changed that. Now, it is possible for the biological female contribution to procreation to be made by at least two women, one who contributes the genetic material (the ovum or gamete donor) and one who gestates and gives birth to the child. ${ }^{135}$ We have been forced to recognize that giving birth is no longer the only way to be a mother or female biological parent. With an understanding of the separation of the genetic and gestational aspects of biological maternity, we can begin to analyze whether the genetic component or the gestating and birth component of the female contribution ought to be privileged in custody or visitation disputes.

Once maternity has been disassembled by assisted reproductive technologies, courts' unstated assumptions about parenthood are exposed. The unstated assumption courts use more and more frequently in disputes arising from assisted reproductive technologies is that genetics is the core identity of the child, and therefore genetic contributors ought to be seen as the legal parents. ${ }^{136}$ This argument, based in genetic essentialism, is rooted

husband is father of child when faced with genetic evidence that another man was the father); and Witso v. Overby, 609 N.W.2d 613 (Minn. Ct. App. 2000) ("A positive genetic test thus creates a presumption of paternity that would, in this action, compete with the presumption of paternity applicable to the mother's husband"). This is an important adaptation in the law, but not relevant to this case or argument, so I am bracketing it for now.

${ }^{134}$ Johnson v. Calvert, supra note

135 There also may be a third woman included in the analysis of maternity--the intending, social, or adoptive mother--who may or may not be a biological mother. As technologies dip deeper into the well of interventions into human reproduction, we may be adding more biological roles. One of the cloning techniques used involves taking an enucleated cell from one person (who could be one of the biological mothers) and inserting the genetic or DNA material from another person (biological mother or father) and then having another woman gestate the embryo (another biological mother). This could result in three biological mothers.

${ }^{136}$ I see this trend in Johnson v. Calvert, 851 P.2d 776 (Cal. 1993), Culliton v. Beth Israel Deaconness Medical Center, 435 Mass. 285, 756 N.E.2d 1133 (2001); Soos v. Superior Ct., 897 P.2d 1356 (Ariz. Ct. App. 1994); In re O.G.M., 988 S.W.2d 473 (Tex. Ct. App. 1999), Litowitz v.Litowitz, 10 P.3d 1086 (Wash. Ct. App. 2000) ("Here, Becky did not contribute any gametes to the preembryos. Thus, under a Davis analysis, she does not have a constitutional right to procreate. But David is a progenitor and, therefore, he has a constitutional right not to procreate") Id. at 1092, reversed, In Marriage of Litowitz, 146 
in a male-biased perspective on reproduction. ${ }^{137}$ Were a non-sex-based or "neutral" perspective used, genetics alone, or even genetics and intention at conception, would not be the defining element of legal parenthood. Fairness requires that we remove this male-bias from courts' analyses of parenthood in ART cases and apply a more equitable analysis that respects the biological realities of reproduction for both sexes. Principles of justice urge us to expose the male-bias in the ways courts subtly or overtly use genetics as the primary descriptor of parenthood ${ }^{138}$ and even motherhood.

In evaluating the contributions of males and females to reproduction, we can measure many things: their intent to procreate, their genetic contributions, other biological contributions (including bonding and pre-birth nurturance), the relationship between parent and fetus/child, and post-birth social nurturance. My argument in this essay is based solely on prenatal biological contributions, since postnatal social and physical contributions-except for lactation (for which bottle-feeding can be

Wash.2d 514, 48 P.3d 261 (2002); Belsito v. Clark, 67 Ohio Misc.2d 54, 644 N.E.2d 760 (Ohio C.P. 1994), In re Baby M, 537 A.2d 1227 (N.J. 1988), and Perry-Rogers, despite the courts' rhetoric in each of these cases that decisions were based on intentions. In all of those cases, the court found the genetic contributors to be the parents, in some cases even when the intentions at the time of conception were arguably different. But see Doe v. Doe, 710 A.2d 1297 (CT 1998); In re Marriage of Buzzanca, 72 Cal.Rptr.2d 280 (Cal.App. 4 Dist., 1998); R.R. v. M.H., 689 N.E.2d 790 (MA 1998).

137 Accord, Barbara Katz Rothman, Daddy Plants A Seed: Personhood Under Patriarchy, 47 Hastings L.J. 1241 (1996). Janice Raymond calls this "ejaculatory fatherhood." RAYMOND, WoMEn AS WomBs, supra note 127, at Chapter 2.

${ }^{138}$ In contrast to my argument that the law is moving toward relying more on genetics to define parenthood, Janet Dolgin powerfully argues that in law, women have been denominated mothers based on their biological connections to a child, but men have needed more than biology, or their genetic connection, to be entitled to paternity. Dolgin, supra note 128. She argues that courts favor men who have formed a familial relationship with the child's mother when determining paternal rights, rather than looking solely to their genetic connection to the child. This seems borne out in recent paternity cases, where conduct and relationships trumped the need for genetic testing as the indicia of paternity: In re Kim F., 744 N.Y.S.2d 777 (N.Y.A.D. 4 Dept.,2002) \& People ex. Rel. J.A.U. v. R.L.C., 47 P.3d 327 (Co., 2002) and In re Raphael P., 118 Cal. Rptr.2d 610 (Cal. App., 1 Dist. 2002). But see Walter v. Gunter, 788 A.2d 609 (Md. 2002) where putative father's child support obligation was vacated after genetic testing excluded him as the father. 
substituted)—can be equally contributed by males or females. ${ }^{139}$ With regard to "intent to procreate," men and women are also in parity - they can each intend to reproduce and each can intend to become the parents who will rear the children. Applying an intent standard for determining parenthood is free of sex-bias, ${ }^{140}$ because men and women have equal opportunities to intend to be parents. ${ }^{141}$ But men and women are not equivalent in their prenatal biological contributions to the birth of a child. The only biological way that men contribute to reproduction is through the genetic contribution of their gametes. ${ }^{142}$ Men contribute half the genetic

\footnotetext{
${ }^{139}$ Linda Lacey objects to a focus on biological motherhood as too dismissive of the needs and interests of infertile women for whom any biological motherhood is not an option or for whom only genetic motherhood is an option. Lacey, supra note 14 . If I can play out her arguments with those I make in this essay, I believe her claim would be that my 'biological essentialist' argument is as flawed as a 'genetic essentialist' argument, for it devalues and ignores infertile women's interests and needs in "having children." Accord Barbara Berg, supra note 14. Lacey does recognize, however, that incorporating the infertile woman's perspective into the analysis still doesn't answer the question of who should have custody when there are disputes. ("I do not contend that adding the infertile woman's voice to the dialogue will provide easier answers to complex problems." Lacey, supra note 14, at 195.)

140 Several courts have used an "intent" standard to determine parentage in disputed surrogacy custody cases. Johnson v. Calvert, supra note 26; Buzzanca v. Buzzanca, 77 Cal.Rptr.2d 280 (Cal.Ct.App. 1998); McDonald v. McDonald, supra note 67.

${ }^{141}$ In cases such as the dispute between the Fasanos and Rogerses, an "intent" standard does not advance the analysis, since both parties equally intended to create a child through in vitro fertilization and embryo transfer. Because of the intent standard's inadequacy in a context where embryos are stolen, misappropriated, or switched, Alice Noble-Allgire recommends that "intent" be combined with a "best-interests" standard, recognizing that such an approach would weigh more heavily in favor of the gestating mother, all other things being equal. Noble-Allgire, supra note 79, at 584. While I appreciate Noble-Allgire's arguments a great deal, I would urge us to reject an intent standard, unless it is based solely on intent to create a child. Courts have used the intent standard to analyze questions about intent to rear the child. See, e.g., Johnson v. Calvert, supra note 26 and McDonald v. McDonald, supra note 67. To me, this misapplication of an intent standard transforms a reproductive and family-based inquiry into a contract-based inquiry, reflective of market values more than familial/relational values. For a valuable discussion of market-based versus family-values-based versus genetics-based analyses regarding new reproductive technologies, see Janet L. Dolgin, Choice, Tradition, and the New Genetics: The Fragmentation of the Ideology of Family, 32 ConN. L. REV. 523 (2000).

142 Barbara Katz Rothman, Recreating Motherhood: Ideology and technology in a Patriarchal Society, supra note 79; Janice Raymond, Women as Wombs, supra note 127.
} 
material that defines the child's DNA. Women have two biological ways to contribute to reproduction-the genetic contribution of their gametes and the biological connections of gestation and birth which form a direct relationship with the fetus/child. If we privilege genetics over gestation, we are privileging the only thing that men can do as the measure of parenthood, that is, we are using only the contribution of gametes to define legal parenthood. ${ }^{143}$

Women, like men, contribute half the genetic materials that define the child's DNA, but women also contribute the physical, biological environment and nutrients that enable the combined male and female gametes to grow to become a baby. The latter biological role has no male equivalent. Pregnancy/gestation is biological and relational-the crux of the biology is the relationship between pregnant woman and child in utero. In an analysis that prioritizes genetics as the definition of legal parenthood, those biological functions that women additionally do during reproduction, i.e., gestate, labor and give birth to a child, become of lesser importance, or even no importance, in defining legal parenthood. ${ }^{144}$ A genetics-based analysis violates principles of sex equality, because it counts all the things that men do in procreation, but does not count all the things that women do in procreation. To value those aspects of procreative contribution which track the sum total of what men do, but ignore or devalue those aspects of procreative contribution that only women do, unjustly discriminates against women. Therefore, measuring legal parenthood first and foremost by what men biologically contribute (genetics) unfairly favors men, by encoding their experiences of procreation as the dominant measure of parenthood. ${ }^{145}$ Both genetics-based and biologicalcontribution-based

143 Ruth Halperin-Kaddari, Redefining Parenthood, 29 CAL. W. INT'L L. J. 313 (1999) ("Conventional dichotomy of genetic versus social construction of parenthood is more reflective of the male experience of parenthood than the female experience"), Id. at 325-6. Professor Halperin-Kaddari argues that Israeli law makes genetics the ultimate force and has unintended patriarchal consequences.

144 In Johnson v. Calvert, supra note 26, the California Supreme Court named genetic donors as the parents, completely overriding any legal parental claims by the gestational surrogate mother. The court argued that it was persuaded by "intent," not genetics, but the genetic essentialism of the opinion was clear.

145 The court in Soos v. Superior Court, 897 P.2d 1356 (Ariz. Ct. App. 1994) decided the equality issue completely differently. Finding the state's surrogate statute violative of equal 
analyses of parenthood may be criticized for their "biological essentialism," were that the only consideration that courts assessed in determining parenthood.

Feminist legal scholars, feminist social scientists, and feminist political theorists have carefully illustrated the dominant historical tendency of law and society to privilege males over females through the conscious, subconscious or unconscious use of unstated assumptions and male-biased perspectives. I am arguing that the newly developing genetics-based analysis of motherhood (and parenthood generally) continues in that discredited tradition, and therefore must be abandoned.

An impartial and more inclusive approach would value all the contributions to reproduction made by both sexes and determine presumptive custody by evaluating which potential legal parent made the most significant contribution (biologically, relationally, and psychologically) to the child's life and well-being. This kind of analysis sounds strikingly similar to the "primary caretaker" analysis in family law ${ }^{146}$ or even the "best

protection when it declares the surrogate the legal mother of the child born as a result of a surrogate parentage contract, A.R.S. § 25-218(B), the court reasoned that, since Arizona law allows a man to rebut the presumption of legal paternity in another by proving genetic fatherhood, it should afford a woman the same right. Although the woman giving birth (the gestational mother) is presumptively the mother, the law must afford the female genetic progenitor an opportunity to rebut that presumption of maternity with evidence of the genetic tie. "A woman who may be genetically related to a child has no opportunity to prove her maternity and is thereby denied the opportunity to develop the parent-child relationship. ... The Mother has parental interests not less deserving of protection than those of the Father." Id at 1360. The court errs in its analysis because it equates a legal presumption based on social concerns (paternity in the husband of the mother) with a legal presumption based on biological facts (maternity in the woman who gestates and gives birth to the child). Men and women are not in the same situation with regard to reproduction because of critical biological differences. This fundamental biological difference shows that Arizona is not treating similarly situated persons differently in violation of equal protection when it creates an irrebuttable presumption of maternity in the gestating woman.

146 See, e.g., Garska v. McCoy, 278 S.E.2d 357, 360-61 (W. Va. 1981) (applying primary caretaker presumption to establish custody for young child). Accord, Mary Ann Mason, Custody Wars: Why Children Are Losing the Legal Battle and What We Can Do about it (Basic Books 2000) (proposing a primary parent preference). Something more akin to the primary caretaker role has also been incorporated into the American Law Institute's Principles of Family Dissolution, Section 2.09, which allocates responsibility and time with the child post-dissolution to the parents in proportion to the time they spent relating to and nurturing the child prior to the dispute. Principles of the Law of Family Dissolution: 
interests of the child" analysis. ${ }^{147}$ That gestating birth mothers would presumptively prevail in these contests is not a function of the inequitable application of a biased norm, as in a genetics-based analysis, but a reasoned measure of the biological and relational facts of child in utero's life. $^{148}$ Gestation, labor and delivery are the sine qua non of bringing children into the world. Perhaps some day children will be "grown" entirely in vitro, ex utero, through ectogenesis, ${ }^{149}$ but we are not there yet and will not be for quite some time. ${ }^{150}$ Couples who use in vitro fertilization to

Analysis and Recommendations, 2.09 (Tentative Draft No. 3 Part I, March 20, 1998) By recognizing the value of the relational, nurturing role to the well-being of the child, the ALI principles replicate the kind of analysis proposed here. The nine months of prebirth nurturance in utero would be valued in the same way that the pre-dissolution nurturance is valued by the ALI Principles.

${ }^{147}$ After this article was drafted, but before it was published, Ilana Hurwitz published her thoughtful article on Collaborative Reproduction, supra note 76, reaching a very similar conclusion.

148 See e.g., Marie Ashe, Law-Language of Maternity: Discourse Holding Nature in Contempt, 22 New ENG. L. Rev. 521 (1988). Janet Dolgin instructs us that Justice Stewart recognized the relational bond between gestating mother and child in his dissent in Caban v. Mohammad, 441 U.S. 380, 397 (1979) ("Parental rights do not spring full-blown from the biological connection between parent and child. They require relationships more enduring. The mother carries and bears the child, and in this sense, her parental relationship is clear"), as did Justice Stevens in his dissent, id. at 405 (discussing a "symbiotic relationship between mother and child" creating a "physical and psychological bond"). Dolgin, supra note 128, at 659-660. My argument emphasizes that, unlike the language used by these two Justices, the bond between gestating mother and child is a biological bond, i.e., not solely psychological, and that the biology of pregnancy is a biology about the relationship between mother and child. The point of quoting the Caban majority and dissent is to illustrate that the Supreme Court is very capable of recognizing the powerful connection between gestating mother and child as a component of parenthood.

${ }^{149}$ Julien S. Murphy, Is Pregnancy Necessary? Feminist Concerns about Ectogenesis, in Feminist Perspectives in Medical Ethics 181 (Helen Bequaert Holmes \& Laura M. Purdy, eds, Indiana U. Press, 1992). That day may be sooner than we think, see Robin McKie, Men redundant? Now we don't need women either; Scientists have developed an artificial womb that allows embryos to grow outside the body, THE OBSERVER, February 10, 2002.

${ }^{150}$ Some early feminist theorists yearned for the day when children could be gestated ex utero, thinking that technology would liberate women. See e.g., Shulamith Firestone, The Dialectic of Sex: The Case for Feminist Revolution (NY: William Morrow, 1970). 
create embryos still need a woman to gestate the child or their embryos die or remain frozen in liquid nitrogen. Though both men and women equally contribute gametes and DNA to a child, ${ }^{151}$ a woman's many months' gestation, labor, and delivery necessarily constitute a more significant biological and relational contribution to the child's existence than genetics.

The most troubling problem with a genetic essentialist approach is that it ignores this post-conception, prenatal biological, relational and psychological connection between mother and child. Biologically, the placenta, an organ that is genetically part of the fetus, but also responsible for maternal metabolic changes during pregnancy, physically connects the mother and fetus. ${ }^{152}$ Maternal hormones, such as adrenaline, produced in response to emotions such as anger, anxiety, and fear have been shown to prompt kicking by the fetus, behaviorally linking mother and fetus. ${ }^{153}$ Psychological analyses of women's experiences during pregnancy demonstrate a positive attachment to the fetus that develops during the first trimester of pregnancy and increases throughout the gestation period. ${ }^{154}$ Specifically, attachment has been shown to dramatically increase after the fetus shows "clear signs of life" such as movements and quickening. ${ }^{155}$ Behavioral studies of expectant mothers have reported that women engage in attachment behaviors, such as talking to the fetus, calling it by a pet

I am not so optimistic.

${ }^{151}$ Though gametes are equally contributed by men and women, the process by which women contribute gametes to in vitro fertilization is significantly riskier and more intrusive than the process by which men contribute gametes, see infra n. 147. This physical fact may militate in favor of female gamete providers in disputes with male gamete providers over embryos or children. See in part, argument for Sue Davis in Davis v. Davis, 842 S.W.2d 588 (TN 1992), cert. denied, 507 U.S. 911 (1993); argument for Ruti Nachmani in Nachmani v. Nachmani, 50(4) P.D. 661 [Nachmani II; Israel]; arguments in A.Z. v. B.Z., supra at note 21.

${ }^{152}$ Pedro Rosso, Nutrition and Metabolism in Pregnancy, Mother and Fetus 133 (1990).

153 Thomas Verny, M.D. \& John Kelly, The Secret Life of the Unborn Child 76, 85

(1981).

${ }^{154}$ Mecca S. Cranley, the developer of the first measurement scale of maternal-fetal attachment, defined prenatal "attachment" as "the extent to which women engage in behaviors that represent an affiliation and interaction with their unborn child. Mecca, supra note 79. See also Jeanne T. Grace, Development of Maternal-Fetal Attachment During Pregnancy, 38 NuRsing ReSEARCH 4, 228-232 (1989).

${ }^{155}$ Mario Mikulincer and Victor Florian, Maternal-Fetal Bonding, Coping Strategies, and Mental Health During Pregnancy - the Contribution of Attachment Style, 18 J. OF SociaL and Clinical Psychology 3, 256-257 (1999). 
name, reprimanding it for moving too often, and offering it food when they are eating, and adopt psychological mindsets in preparation for birth. ${ }^{156}$

A genetic essentialist analysis constructs the gestating mother as a mechanical incubator rather than as a interactive being with the fetus. As Justice Kennard of the California Supreme Court writes in her dissent in Johnson v. Calvert:

A pregnant woman intending to bring a child into the world is more than a mere container or breeding animal; she is a conscious agent of creation no less than the genetic mother, and her humanity is implicated on a deep level. ${ }^{157}$

Even if the male bias of a genetics-based analysis of parenthood were too subtle to see in its other formulations, the dehumanizing of the fundamental female gestational contribution to reproduction by seeing a pregnant woman as a "womb to rent" or fetal container, confirms the hypothesis of malebias.

No part of what a male contributes to reproduction is devalued in a genetics-based analysis; the largest part of what a female contributes to reproduction is devalued and dehumanized in an analysis that relies on a genetic definition of legal parenthood. In addition to the differential qualitative contributions of men and women to reproduction, the risks of the process of reproduction for men and women differ significantly, as do the risks for gestating women over gamete-donating women. ${ }^{158}$

${ }^{156}$ Cranley's maternal-fetal attachment scale identified and measured six subscales of maternal behavioral-psychology. These included: 1) differentiation of self from fetus; 2) interaction with fetus; 3) attributing characteristics and intentions to the fetus; 4) giving of self; 5) role-taking; and 6) nesting. Cranley supra note 79 at 282. A subsequent study by Grace determined that behaviors associated with role-taking and giving of one's self were most positively correlated with increased gestation. Grace supra note 154.

157 Johnson, 851 P.2d. at 797-98. See also Julien Murphy, Should Pregnancies Be Sustained in Brain-Dead Women?: A Philosophical Discussion of Postmortem Pregnancy, in HEALING TECHNOLOGY: FEMINIST PERSPECTIVES 135-159 (U. Mich. 1989) (emphasizing the need to respect a woman's autonomy through recognizing consciousness and choice as critical elements of pregnancy and reproduction).

158 The egg donation/retrieval process for gamete donors is no simple matter. Women must take regular hormone injections to properly time their cycles, plus other drugs to create 
The birth [gestating] mother risks sickness and inconvenience during pregnancy. She faces the certain prospect of painful labor. She even risks the small but qualitatively infinite possibility of death. Throughout all of this discomfort and uncertainty, it is her body which remains the cradle for the growing fetus. By comparison, the physical involvement of the sperm donor is de minimis. While the egg donor physically risks more than the sperm donor, her level of physical involvement pales in comparison with the gestational host. ${ }^{159}$

An extensive feminist bioethics literature addresses these significant sex-based differences, their implications, and how we ought to analyze ARTs for men and women in all of their roles. ${ }^{160}$ Whether as a

controlled ovarian hyperstimulation (to ripen and produce more eggs), must be monitored at clinics, must communicate with the clinical team, and then must undergo intrusive surgery (laparoscopy) or transvaginal manipulation with ultrasound guidance to retrieve the eggs. See e.g., Nancy Klein, Gretchen Sewall and Michael Soules, Donor Oocyte Program at University of Washington Medical Center, in NEW WAYs OF M AKING BABIES 3, 10 (Cynthia Cohen, ed., Indiana U. Press 1996). In a parallel analysis to that of genetic versus gestational contributions, a weighing of the biological contributions between female and male gamete donors reveals that female gamete donors make a significantly greater biological contribution by undergoing a more difficult and time-consuming process in order to donate.

${ }^{159}$ John Lawrence Hill, What Does It Mean to be a "Parent"?: The Claims of Biology as the Basis for Parental Rights, 66 N.Y.U. L. REV. 353, 408 (1991).

${ }^{160}$ The list of articles would be too long. Even a partial list of books is ext ensive: see, e.g., Barbara Katz Rothman, Recreating Motherhood: Ideology and Technology in a Patriarchal Society (W. W. Norton 1989); Feminist Perspectives in Medical Ethics 169-300 (Helen Bequaert Holmes \& Laura M. Purdy, eds. (Indiana U. Press, 1992); JANICE G. Raymond, Women as Wombs: Reproductive Technologies and the Battle Over Women's Freedom (1993); Christine Overall, Ethics and Human Reproduction (Harper 1987); Patricia Spallone, Beyond Conception: The New Politics of Reproduction (Bergin \& Garvey Press 1989); Valerie Hartouni, Cultural Conceptions: On Reproductive Technologies + the Remaking of Life (U. Minnesota Press, 1997); Cyborg Babies: From Techno-Sex to Techno-Tots, Part 3 (Robbie DavisFloyd \& Joseph Dumit, eds., Routledge 1998); Embodying Bioethics: Recent Feminist Advances, Part II (Anne Donchin \& Laura M. Purdy, eds., Rowman \& Littlefield, 1999); Reproduction, ethics, and the Law: Feminist Perspectives (Joan C. Callahan, ed., Indiana U. Press, 1995); Susan Sherwin, No Longer Patient: Feminist Ethics \& Health 
matter of natural reproduction or assisted reproduction, equality requires that gestation be fully valued for the extraordinary female contribution (biological and relational) to reproduction that it is. A genetics-based analysis of parenthood fails to meet that test because of its sex-bias. When contributions of genetic materials and contributions of gestation, labor and birth are treated without bias and fairly compared, it becomes clear that a gestating mother is entitled to presumptive primary legal parenthood, with its concomitant rights to custody and visitation.

To reach the conclusion that women's biological contributions of gestation, labor and birth ought to be included in an analysis of biological parenthood does not mean that a man's or woman's genetic contribution to a child ought to be ignored and devalued instead. Nor does it imply that the intentions and desires of infertile couples who cannot contribute genetically or biologiocally are to be ignored. My sole argument here is that biological contribution is one important aspect of legal understandings of parenthood, and in any analysis where weight is given to biological contributions, a primarily genetics-based definition of biological contribution is sex-biased and must be abandoned.

The court in Perry-Rogers v. Fasano denies that it is applying "solely" a genetics-based analysis of parenthood, yet it reaches a conclusion that effectuates that end. "But for" genetics, and in the absence of legal adoption, no other reason exists to give any legal rights, especially exclusive legal rights with regard to Joseph/Akeil to the Rogerses. ${ }^{161}$ While he was being nurtured in utero, born, and cared for at the beginning of his life, the Rogerses did not even know of his existence. For the almost eight additional months of pregnancy post-clinic notification of the mistake and then the time after Joseph/Akeil's birth before their genetic parenthood was confirmed, the Rogerses were unaware of his existence. During that same time period, Donna Fasano developed a relationship with the child and nurtured him daily in her body and through her being. The Rogerses' claim to him, when they discovered the fact of his birth, was genetic, not

Care, Chapter 6 (Temple U. Press, 1992); RoseM arie Tong, Feminist Approaches to Bioethics, Chapters 7-8 (Westview Press, 1997).

${ }^{161}$ In this case there is the signed agreement between the parties, but since the court disregards that agreement when it comes to visitation, it would be odd to conclude that it was enforcing other aspects of that agreement. 
relational. The Rogerses were terribly wronged by the negligence of the IVF clinic, but the clinic's mistake with respect to the misappropriation of their embryo does not seamlessly translate into parental rights in the child, as the court makes it appear. They have been harmed, and harmed by reproductive technologies, but being harmed does not make one a legal parent.

If genetics had not been the salient feature of parenthood in its reasoning, the court could have found that the Rogerses had a valuable claim against the IVF clinic, but that they had no standing to seek a declaration of exclusive legal parenthood. Ironically, the court instead found that the Fasanos had no standing to bring a claim for visitation. Therefore, the court's denial of reliance solely on genetics is contradicted by the facts of the case and the resolution it reached. Somehow an ideology of genetic essentialism, with its male-bias on issues of assisted reproductive technologies, crept in as the court's unstated assumption. The ensuing gender-bias undermines the possibilities of achieving a just result.

\section{Race Issues and ART mistakes}

The Perry-Rogers v. Fasano opinion does not acknowledge the racial issues raised by this case, ${ }^{162}$ and yet the court seems to have used an unconscious or unspoken ideology about race to reach its conclusion that Donna Fasano was wrongful in bonding with Joseph/Akeil. Racial difference is the elephant in the living room that we are not supposed to mention. Practically every newspaper account of this extraordinary situation mentions the racial differences between the couples and the between the twins. ${ }^{163}$ This subsection on race issues and ART mistakes

\footnotetext{
${ }^{162}$ Race is only mentioned in one paragraph in the facts. Perry-Rogers, 276 A.D.2d at 69.

${ }^{163}$ See, e.g, Michael Grunwald, In Vitro, in Error, and Now in Court; White Mother Given Black Couple's Embryos Will Give One 'Twin' Back, WAsh. Post, March 31, 1999, at A01, available in 1999 WL 2208496; Samuel Maull, Teaneck Parent Opposing 'Twin' Visits, REC. N. N.J., February 4, 2000, at A06, available in 2000 WL 15796459; Bob Groves, Lawyers Argue over Visitation in Case of Misplaced Embryo, REC. N.N.J., June 10, 2000, at A03, available in 2000 WL 15818246; Kathleen Parker, Baby Case Ends with Multiracial Scrambled Eggs, Chicago TriB., June 21, 2000, at 17, available in 2000 WL 3677176; Samuel Maull, White couple ask court to let them visit black baby that was born to them, APWIRES 19:54:00, October 18, 2000; Jim McClean, Couples war over implant mix-up baby: White parents of black child accused of trying to exploit fertility treatment fracas, Herald (Glasgow, Scotland), October 20, 2000, at 11, available in 2000 WL 28098709;
} 
explores the role of racial difference in the facts of the Perry-Rogers $v$. Fasano case, and how race influenced the way the court resolved the dispute about parenthood claims. The court's strategy of "colorblindness" or ignoring race on the surface, but using race-based assumptions to produce the result, imposes a damaging race-bias that in this instance leads to a renewed kind of biological racism.

Biological racism maintains that racial groups are physically distinct species, with specific characteristics or capabilities attributable to each racial group based on the group members' similar genes and biology. The racism part of biological racism separates or divides human beings into hierarchically ranked groups with more or less power and privileges; the biological part of biological racism makes those divisions seem scientifically supportable and natural, as if they were based on real racially-based, physical distinctions. One's physiognomy, or one's racially distinct features, becomes the signifier of racial group membership. But biological racism does more serious harm than signifying racial group membership; it divides people into groups in ways that do not necessarily reflect their agency, experiences, understandings, or even their relationships. One of the residual effects of an assumption about 'race as biology' (or 'race as physiognomy') is that it is carries with it social or cultural norms and expectations. Those expectations, including understandings about the inappropriateness of interracial intimacy, ${ }^{164}$ endure in our social and cultural conduct and get incorporated into legal decision-making, even if they are no longer openly sanctioned by law, as happened in Perry-Rogers v. Fasano.

An assumption about race as a biological, genetic fact, combined with cultural norms that still discourage interracial intimacies, including interracial parenthood, limits Joseph/Akeil's options to have a familial relationship with his birth mother (that is, to be with his white mother in addition to his African-American mother). The court's decision punishes Joseph/Akeil for being racially different from his birth family. In this case, it actually punishes him for being dark-skinned and appearing to be African-American. I do not want to be understood to be saying that

Cerisse Anderson, Couple's Visitation Rights are Rejected in Case of Mixed-up In Vitro Births, N.Y.L.J., October 27, 2000, at 1, (col. 4).

${ }^{164}$ Rachel Moran, Interracial Intimacy: The Regulation of Race and Romance (Chicago: University of Chicago Press, 2001). 
Joseph's being placed with his genetic parents, the Rogerses, is punishment. I am definitely not saying that. But, I am saying that it clearly is punishment to completely sever a child's connection with his birth mother and brother, despite their strong desires to stay attached and continue the relationship.

My argument is that the Perry-Rogers v. Fasano court defaulted to a simplistic race-matching approach to parenthood, determined by genetics and physiognomy. While part of that default is the result of the genetic essentialism discussed in an earlier section of this essay, the other part is attributable to an ideology of biological racism. In either case, whether due to genetics alone (genetic essentialism) or race and genetics (biological racism), Joseph/Akeil is forced to suffer the loss of his mother and brother. The consequences for Joseph/Akeil of the court's biologically race-based assumptions are as painful and real as if they were carved into his body by the execution apparatus/machine from Kafka's The Penal Colony. ${ }^{165}$

To illustrate the role that race played in the court's decisionmaking, I will give a rough overview of the multiple steps in my argument about the race-bias of the court's reasoning, and then develop some of its subparts more fully. First, if the court is not relying solely on genetics as the descriptor of legal parenthood, as it states, then we must examine why the court reached the decision it did. That is the purpose of this subsection. Second, the court explains that Donna Fasano was denied standing to make a claim to maintain a relationship with her infant on the grounds that she was wrongful in bonding with the infant. Third, since Fasano was made aware of the clinic's error early in her pregnancy, she should have known that both, one, or neither of her twins might have been the genetic child of another couple. Fourth, despite the general uncertainty about both children's genetic parentage during the pregnancy (because of the clinic mistake, or for that matter, in any ART created-pregnancy, since human error is always possible), the court never requires Fasano or any mother made aware of an ART clinic mistake to genetically test at their birth all of her infants born from that pregnancy. Fifth, nor does the court say that in the absence of genetic testing, parents utilizing ARTs are wrongful in bonding with any of their children. Sixth, the court never faults Donna Fasano for bonding with Vincent, the other twin. Seventh, the only reason

\footnotetext{
${ }^{165}$ Franz Kafka, In the Penal Colony, in LAW IN LITERATURE: LEGAL THEMES IN SHORT STORIES 217 (ed. Elizabeth Villiers Gemmette, 1995).
} 
Donna Fasano could have had to know that she "shouldn't" have bonded with Jospeh/Akeil when he was born was his racial physiognomy that appeared to differ from her and her husband's. Eight, therefore, the court uses physical features correlated with racial groups to delimit the range of legally acceptable relationships for Joseph/Akeil and the Fasanos. These race-based assumptions and relational limitations are throwbacks to a flawed biological racism that has been roundly rejected by scientists and scholars.

My biological racism critique of this case identifies the court's unstated assumptions in the opinion as (1) race is reducible to a visually detectable set of characteristics (that are genetically transmitted and physical) and (2) interracial family relations are unseemly and should be avoided. Despite powerful articulations by courts and scholars denouncing biological racism ${ }^{166}$ and denouncing race-based prohibitions on family relations ${ }^{167}$ these concepts have found subtle ways to insiunate themselves in the Perry-Rogers v. Fasano decision.

The ideology of 'race as a biological category,' a concept that has fueled much racist thinking, is no longer viable as a formal matter in law and society. ${ }^{168}$ In 1987, the United States Supreme Court in St. Francis College v. Al-Khazraji, stated:

There is a common popular understanding that there are

\footnotetext{
${ }^{166}$ See text accompanying fn 169 , infra.

${ }^{167}$ Loving v. Virginia, 388 U.S. 1, 87 S. Ct. 1817 (1967); Palmore v. Sidoti, 466 U.S. 429, 104 S.Ct. 1879 (1984).

${ }^{168}$ See e.g., Barbara K. Kopytoff \& A. Leon Higginbotham, Racial Purity and Interracial Sex in the Law of Colonial Antebellum Virginia, 77 Geo. L.J. 1967, 1981 (1968); IAn F. Haney Lopez, White By Law: The Legal Construction of Race (N.Y.U. Press 1996); Haney Lopez, The Social Construction of Race: Some Observations on Illusion, Fabrication and Choice, 29 HaRv. C.R.-C.L. L. Rev. 1, 6 (1994); Richard Ford, Race As Culture? Why Not?, 47 UCLA L. REV. 1803 (2000) ("It is now almost common knowledge that the idea of raceas-biological-difference has been discredited as a matter of science") id. at 1806; Keith E. Sealing, Blood Will Tell: Scientific Racism and the Legal Prohibitions Against Miscegenation, 5 Mich. J. RACE \& L. 559 (2000); Donald Braman, Of Race and Immutability, 46 UCLA L. REv. 1375 (1999) ("the Court has not held-indeed, could not have held—racial status to be biological, but [sic] it has instead treated that status as the product of institutions that were necessarily social and political") $i d$. at 1446.
} 
three major human races--Caucasoid, Mongoloid, and Negroid. Many modern biologists and anthropologists, however, criticize racial classifications as arbitrary and of little use in understanding the variability of human beings. It is said that genetically homogeneous populations do not exist and traits are not discontinuous between populations; therefore, a population can only be described in terms of relative frequencies of various traits. Clear-cut categories do not exist. The particular traits which have generally been chosen to characterize races have been criticized as having little biological significance. It has been found that differences between individuals of the same race are often greater than the differences between the "average" individuals of different races. These observations and others have led some, but not all, scientists to conclude that racial classifications are for the most part sociopolitical, rather than biological, in nature. ${ }^{169}$

That racial groupings are often correlated with certain physical features does not make the concept of race a biological reality. ${ }^{170}$ Racial

\footnotetext{
${ }^{169}$ St. Francis College v. Al-Khazraji, 481 U.S. 604, 610, n. 4 (1987) (see generally string cite in this footnote of works rejecting the notion of a biological category of race)

${ }^{170}$ See, e.g., Sandra Soo-Jin, Joanna Mountain, and Barbara Koenig, The Meanings of "Race" in the New Genomics: Implications for Health Disparities Research, 1 YALE J. Health Pol'y L. \& Ethics 33 (2001); Ian Haney Lopez, Race, Ethnicity, Erasure: The Salience of Race to LatCrit Theory, 85 CAL. L. REV. 1143,1152 (1997); Reva Siegel states that:
}

Current scientific and social-scientific accounts of race do not treat race as a group-categorical distinction but instead conceptualize race in terms of group-salience - as arising out of the uneven incidence of genetic or phenotypic or social traits in a population; this is the approach to race reflected in historical-race and culture-race discourses. Further, historical-race and culture-race discourses understand race as aggregations of socially relevant traits - that is, they conceptualize race as made of norms, understandings, cognitive and practical skills, material resources, life experiences, practices, activities, memories, concerns, commitments, fears, interests, desires, and identifications that are distributed in a society in group-salient patterns that persist with variable intensity over time. Some version of this approach to 
classifications may be associated with genetically transmitted, physical characteristics like skin color, hair color and texture, eye color and shape, nose size and shape, facial bone structure, and body size and shape, but those correlations or associations cannot scientifically be translated into biological definitions of race and certainly should not be understood as an analogue of legal parenthood. The variations of each of those characteristics within a designated "race" are as broad as the variations between delimited "races."171

The power of race, or racial thinking, is derived from the supposition that race is biological and hence, immutable - inextricable from the essential character of individuals. Historically, race has been identified through physiological characteristics such as skull size, skin color, facial features, and other qualities readily available for scrutiny by the passing observer....

conceptualizing race as a social formation seems inevitable in debates over the justice of our distributive practices, however complexly we model the problem in institutional, dynamic, economic, or other terms. For if we want to identify particular social practices that are distributively just with respect to race, it would indeed seem that, whatever our view of distributive fairness, we would have to reason about race as it is socially instantiated, whether in historical or cultural terms.

Reva B. Siegel, Discrimination in the Eyes of the Law: How "Color Blindness" Discourse Disrupts and Rationalizes Social Stratification, 88 CALIF. L. REv. 77, 99-100 (2000).

${ }^{171}$ Anthony Appiah, The Uncompleted Argument: Du Bois and the Illusion of Race, in "Race," Writing, And Difference 21, 30-32 (Henry Louis Gates, Jr. ed., U. Chicago Press 1985); Richard C. Lewontin et Al., Not in Our Genes: Biology, Ideology, And Human Nature (Pantheon Books 1984); Sandra Soo-Jin, Joanna Mountain, \& Barbara Koenig, supra note 160; Renee Bowser, Racial Bias in Medical Treatment, 105 DicKInson L. REV. 365 (2001). Scientists working on the human genome project continue to discover that there are no genetic ways to differ between races. Natalie Angier, Do Races Differ? Not Really, Genes Show, N.Y. Times, Aug. 22, 2000, at F1. Findings from the HGP indicate that $99.9 \%$ of the genome is the same across races and ethnicities. Nature Genome Gateway: http://www.nature.com/genomics/human/slide-show/9.html. 
...the fields of physical or biological anthropology and population genetics have long held that the idea that distinct human races exist is scientifically incorrect, as well as harmful.

The widely accepted consensus among evolutionary biologists and genetic anthropologists is that biologically identifiable human races do not exist; Homo sapiens constitute a single species, and have been so since their evolution in Africa and throughout their migration around he world. Population genetics provides the best evidence for this conclusion: The genetic variation within a socially recognized human population is greater than the genetic variation between population groups. ${ }^{172}$

How we treat people as members of racial groups based on these physical features and perceived differences is not about biology at all. Perceptions of which physical differences signify inclusion or exclusion in certain racial groups (and even what constitutes a racial group) ${ }^{173}$ have changed over time and place and are politically and socially malleable. Ian Haney Lopez notes, "Race, until recently, has been widely understood as something rooted in the biology of human differentiation.... [however] all racial identities... are intelligible only as social constructions. Race is best understood as a process of social differentiation rooted in culturally contingent beliefs in the biological division of humans." 174 john powell describes race as "experiential," as a verb, as in "being raced," rather than as a noun or description. ${ }^{175}$

\footnotetext{
${ }^{172}$ Sandra Soo-Jin, Joanna Mountain, \& Barbara Koenig, supra note 162 at 37, 39.

${ }^{173}$ As Martha Mahoney explains, "Race derives much of its power from seeming to be a natural or biological phenomenon, or at the very least, a coherent social category." Martha R. Mahoney, Segregation, Whiteness, and Transformation, 143 U. PA. L. REV. 1659, 1661 (1995).

${ }^{174}$ Ian F. Haney Lopez, Race, Ethnicity, Erasure: The Salience of Race to LatCrit Theory, supra note 160 at 1152 .

175 john a. powell, The "Racing" of American Society: Race Functioning as a Verb Before Signifying as a Noun, 15 LAw \& INEQ. J. 99 (1997). Accord, Kendall Thomas, The Eclipse of Reason: A Rhetorical Reading of Bowers v. Hardwick, 79 VA. L. REv. 1805, 1806-07 (1993).
} 
Socially and culturally constructed ideas about race vary in particular historical moments and locations. ${ }^{176}$ While there are a few scientists today arguing for the persistence of racial categories, mostly for purposes of public health benefits, most scientists and academic scholars refute the concept of biological race. ${ }^{177}$ But, as Haney Lopez instructs:

Though a social construction, race is real. Its reality lies in social practices, including beliefs in natural group divisions and heir significance, not in the abstract "truth" of such beliefs. Recognizing the falsehood of physical conceptions of race cannot serve in and of itself to establish that race is unreal. Nor can it support without more the conclusion that racial rhetoric is inappropriate for discussing groups that have been racialized. The "reality" encountered by such groups does not change in the least with the recognition that race is not biologically real. ${ }^{178}$

My arguments are aligned with Haney Lopez's premises. The court is wrong in both ways that it engages with race-in using biological racebased assumptions and in ignoring race's socio-political impacts when making a decision in a case like this where racial difference is a critical element.

A fair analysis of the custody (or visitation) dispute in PerryRogers $v$. Fasano requires dealing openly with this issue of race, but with an understanding of race as socio-economic, political, ideological and

\footnotetext{
${ }^{176}$ See e.g., powell, supra note 165 (describing the different ways in which race has been understood in American history and culture).

${ }^{177}$ See fn. 160, supra. Some population geneticists have taken issue recently with this position. For example, Neil Risch, of Stanford University, argues that the correlation between race/ethnicity and disease is identifiable through genetics and must be taken into account by biomedical researchers. Nicholas Wade, Race seen as crucial to medical research, 8/2/02 Toronto Star F05, 2002 WL 24326698 (referring to Risch's article in the online journal Genome Biology). Risch identifies five racial categories through genetic markers, classifiable based on historically isolated geographic origins that have traditionally been denominated as races.

${ }^{178}$ Haney Lopez, supra note _ at 1186.
} 
cultural practices, rather than as a biological fact. ${ }^{179}$ The court does the exact opposite: it does not deal with race at all in the open, but applies an assumption about race as a genetic, biological construct that requires a kind of race-matching between parent and child. Genetic essentialism, applied in a race-based culture, yields biological racism. Unlike sex, where biology necessarily informs our understanding of reproduction and parenthood, there is no relevant 'biology of race' to inform our reasoning about reproduction and parenthood.

As I mentioned earlier, the court claims that it is not looking at genetics as the defining feature of parenthood. If we take the court at its word, the only logical inference from the court's decision that the Fasanos were blameworthy for forming a bond with their child is that the court was acting on highly race-conscious assumptions about race and race-matching between parents and children. ${ }^{180}$ In other words, my argument is that the court is either contradicting its own assertions and using a genetics-based approach as I argued in subsections B and C above, or the court is taking race into account sub silentio by using an unexamined biological racebased assumption about parenthood. ${ }^{181}$ Either approach is seriously flawed.

179 Michael Omi \& Howard Winant, Racial Formation in the Untied States: From THE 1960s to the 1980s (1986). See generally, Leslie Bender \& DaAn Braveman, Power, Privilege \& Law: A Civil Rights Reader (West, 1995).

${ }^{180}$ See Part III, B, 3, supra.

181 Discussing other race-based assumptions that intersect with new reproductive technologies, Lisa C. Ikemoto writes: "What may be most disturbing about this procreative technology use is the imagined moment of a black woman giving birth to a white infant, or a white woman giving birth to a black infant....The level of unease generated by interracial birth may also indicate that the notion of race that assumes biologically-inherent difference is still deeply embedded in the more recent notion that racial difference is culturally constructed." Lisa C. Ikemoto, The In/Fertile, the Too Fertile, and the Dysfertile, 47 Hastings L.J. 1007, ___ (1996). Likewise, Patricia Williams assesses the role that racebased assumptions would play if the baby in the Baby $M$ case had appeared black:

What would have happened, for example, if Mary Beth Whitehead had turned out to have been the "passed" descendant of my "filed" godmother Marjorie's mother? What if the child she bore had turned out to be recessively and visibly black?....These questions turn, perhaps, on not-so-subtle images of which mothers should be bearing which children. Is there not something unseemly, in our society, about the spectacle of a white woman mothering a black child? A white woman giving totally to a black child; a back child totally and 
One reason the court's approach in this case is so strange is the court never addresses the issue of the ever-present threat of ART mistakes resutling in parent-child genetic mismatches and mix-ups. This case ought to have been decided with attention to its important precedential value, much like Davis v. Davis ${ }^{182}$ was, as a case of first impression about a custody battle over frozen embryos, or In re Baby $M,{ }^{183}$ a precedential surrogate mother contract case. The reasoning in this case could have served as persuasive authority or guidance for courts across the nation.

Thinking about this more broadly, we realize that without mandatory genetic testing, parents using an ART process cannot know for certain that the children they have borne are their genetic children. It is possible for mistakes to happen in any IVF treatment procedure. ${ }^{184}$ The New York state legislature has not responded to this problem. For that

demandingly dependent for everything, sustenance itself, from a white woman. The image of a white woman suckling a black child; the image of a black child sucking for its life from the bosom of a white woman.

Patricia J. Williams, The Alchemy of Race and Rights: Diary of a Law Professor 226 (Harvard U. Press, 1991). April Cherry, in an important article, also examine the relationship between race, mothering and reproductive technologies, with specific attention to gestational surrogate mothering, although her focus is more on the ways that Black mothers of white children are not appropriately acknowledged in law, rather than the reverse claim I am making in this section that white mothers of black children are also discounted by courts. April Cherry, Nurturing in the Service of White Culture: Racial Subordination, Gestational Surrogacy, and the Ideology of Motherhood

10 TEX. J. WoMen \& L. 83 (2001).

${ }^{182}$ Davis v. Davis, 842 S.W.3d 588 (Tenn. 1992), cert. denied, 507 U.S. 911 (1993).

${ }^{183}$ In re Baby M, 537 A.2d 1227 (N.J. 1988).

${ }^{184}$ Recently another IVF mistake where race was an issue occurred in Britain. Sarah Lyall, Whites Have Black Twins in In-Vitro Mix-up, N.Y. Times, July 9, 2002, at A12. One wonders how often this occurs within a racial group rather than across races, and therefore goes unnoticed or unreported. In Harnicher v. University of Utah Medical center, 962 P.2d 67 (1988, as corrected, March 19, 1999), a sperm mix-up was recognized because the child had distinctly different physical features from the other children, but the difference was not racial. There are also several notorious sperm mix-up cases where the parents were white and the children were of different races. See generally discussion of the Skolnick and the Higgins sperm mix-up debacles in Raizel Liebler, Are You My Parent? Are You My Child? The Role of Genetics and Race in Defining Relationships After Reproductive Technological Mistakes, 5 DePaul J. of Heath Care Law 15 (2002). 
matter, no state legislature has enacted a law requiring all parents to genetically test their children at birth. ${ }^{185}$ Nor has any legislature enacted a law requiring the special subset of parents, those parents whose children were conceived through ARTs, to genetically test their children at their birth. Even absent legislation to that effect, the court may have concluded that justice requires that any parents participating in ARTs have their babies genetically tested at their birth to determine their parenthood as a prerequisite to getting a legal birth certificate and having legal custody.

Since the court never criticized the Fasanos for failing to have post-birth DNA tests done on both their children immediately upon their birth, then what about Joseph/Akeil, but not Vincent, would have indicated to the Fasanos that he was not "their child" and that bonding with him was wrongful? The court was unequivocal in its understanding that the Fasanos acted wrongly in permitting a bond to form with the child Joseph/Akeil, after he was born (if not even while he was in utero), but never indicated that they were wrongful in bonding with Vincent as well:

[A]ny bonding on the part of Akeil to his gestational mother and her family was the direct result of the Fasanos' failure to take timely action upon being informed of the clinic's admitted error. Defendants cannot be permitted to purposefully act in such a[] way as to create a bond, and then rely upon it for their assertion of rights to which they would not otherwise be entitled. ${ }^{186}$

Joseph/Akeil's only characteristics that could have revealed to the Fasanos that they were not entitled to treat him as their son were some of his physical features, including skin color, that are correlated with race. ${ }^{187}$ The court implies that immediately upon Joseph/Akeil's birth, the Fasanos should have recognized his "otherness" (racial difference) from them and severed (or failed to establish) bonds with him. The reason the Fasanos were wrong in their conduct, and therefore not entitled to standing as parents in

\footnotetext{
${ }^{185}$ Not that I would want such a law enacted.

${ }^{186}$ Perry-Rogers, 276 A.D.2d at 76.

${ }^{187} \mathrm{Had}$ his eyes been blue instead of brown, would the court have reached the same conclusion? Had he been long and thin in a family of short, stocky parents, would the court have decided that they were wrongful to let bonding occur? What could it have been but the signs of "racial otherness" or racial difference that motivated the court's conclusion?
} 
this visitation action, was that they failed "to take timely action." They failed to reject their son for his racial otherness when he was born. Lisa Ikemoto speaks about the way race-based assumptions play into these technological mistakes and reveal a kind of biological racism:

The image of a black woman claiming authority over a white child inverts racially-based rules of status and ownership. Second, the historical rule of race is that any child born of a black woman is also black. The use of transracial egg donation to change the conclusion that blackness begets blackness challenges the assumption that black mothers create the traits deemed inferior by white supremacy.

What may be most disturbing about this procreative technology use is the imagined moment of a black woman giving birth to a white infant, or a white woman giving birth to a black infant. Blackness has been so othered that the intimacy, the ultimate intimacy, of the moment seems impossible and strange and perhaps even alien. The strangeness and seeming impossibility of the image only shows the extent to which motherhood has been used to maintain the color line. The level of unease generated by interracial birth may also indicate that the notion of race that assumes biologically-inherent difference is still deeply embedded in the more recent notion that racial difference is culturally constructed. ${ }^{188}$

Patricia Williams calls our attention to the ways that race-based imagery and assumptions in our culture animate our thinking about interracial ART mistakes, "Is there not something unseemly, in our society, about the spectacle of a white woman mothering a black child? A white woman giving totally to a black child; a back child totally and demandingly dependent for everything, sustenance itself, from a white woman."189

\footnotetext{
${ }^{188}$ Lisa C. Ikemoto, The In/Fertile, the Too Fertile, and the Dysfertile, 47 HAstings L.J. 1007, __ (1996) (footnotes omitted).

${ }^{189}$ PATRICIA Williams, supra note 174.
} 
Insights of scholars like Ikemoto and Williams support my conclusion that unconscoius or subconscious race-based assumptions tainted the decisionmaking process in Perry-Rogers v. Fasano.

In line with the argument about how the court treated Vincent differently from Jospeh/Akeil with respect to relying on genetic tests to define parenthood, we need to examine what the court left out about what the Fasanos knew or could have known. The court does not take notice of the fact that the Fasanos had no information about another specific couple who was waiting for the birth of this child. Though they knew there had been a mix-up at the clinic, there is no evidence that they were informed that the Rogerses were anxiously waiting in the wings for the baby that the Fasanos were carrying. For all they knew, the Rogerses could have had babies through the IVF process and chosen to forget the information about the mix-up. Or the Rogerses could have been trying to put that horrific experience behind them. The clinic did not breach the parties' confidentiality by informing them about one another, so the Rogerses did not know about the pregnancy and the Fasanos did not know about the Rogerses. The only reason they would have had for giving up Joseph/Akeil at that time of his birth was the divergence of their and his physical features that correlated with notions of race.

The physical mismatch becomes the sub silentio justification for denying the Fasanos a relationship with their son. ${ }^{190}$ The court impliedly tells us that when Joseph/Akeil was born and the Fasanos noticed his racial difference, that was cause for them to give up their child, rather than further their bond with him. Since the Fasanos were not aware that other "parents" were prepared to take this child at the time of his birth, they would have had to give the child up to the State or the IVF clinic. ${ }^{191}$ It seems extremely unusual to expect a birth mother to give her child to the State, when she wants him herself, solely because he looks different from

\footnotetext{
${ }^{190}$ Ironically, in Harnicher, supra note 24, the Utah Supreme Court chastised the parents who complained because their child had physical features dissimilar to theirs. The court ridiculed the couple and indicated that they should be happy to have given birth to healthy children through this extraordinary technological feat. Obviously, the Perry-Rogers $v$. Fasano court reached the opposite conclusion.

${ }^{191}$ Although after the fact we know that there were people desirous of rearing the child, the Fasanos had no such knowledge at his birth when his racial difference became apparent. If there were no parents to take this child, the Fasanos would have had to relinquish him to the State for foster care or adoption. Considering the fact that they wanted this child, it seems an incredible decision for the court to make.
} 
her. It seems blatantly racist to imply that a person "ought" not bond with a child of a different race. Certainly that conclusion ends up "taking race into account" in an impermissible way (whether mentioned or not).

By not discussing the race, the court is ultimately taking race into account in this unexamined way. No other parents of children born through IVF have been required to test their children upon birth and then, if their genetic make-up is different from their parents due to a clinic mistake, to relinquish them to the State (or fail to bond with them). We have no idea how often this has happened in the absence of racial difference. We also may have no idea how often it happens when there is racial difference, although the "sensational" nature of these cases tends to call them to the media's attention. ${ }^{192}$

The court insists its decision does not turn solely on genetics, but if it is not using genetics as the key, then its decision must turn on race or skin color. No doubt the court would be loath to admit its reliance on race rather than on genetics. Even though the court mystifies its reliance on genetics, if we agree that the real basis for its judgment is genetics, not skin color, then I would still argue that genetic essentialism necessarily ends up taking race into account in an impermissible way. The dividing lines along the circle of genetics, physical features, biological racism, and 'race as a socialpolitical construction' become blurred and the danger of reproducing a racist understanding looms large.

Genetic essentialism creates troubling racial issues, in addition to the troubling sex-based issues discussed in the previous subsection. The application of a genetic essentialist ideological framework in a case like this one proves even more disturbing than in many other ARTs debacles. Most race-based critiques of assisted reproductive technologies argue (1) that these technologies are not adequately available to people of color, (2) that use of these technologies reproduces the racist ideology in our society that values white babies and their physical features over children of color and their physical characteristics, and (3) that people of color will be "victims" of this technology as an underclass of breeders or in ways that will cause them to lose custody of their children. ${ }^{193}$ These powerful critiques of

\footnotetext{
${ }^{192}$ Michael Seamark \& Beezy Marsh, After White Couple Have Black Twins in Test Tube Mix-up, Daily Mail (London), July 9, 2002, LEXIS

193 Dorothy Roberts, Killing the Black Body: Race, Reproduction, and the
} 
racism in society and racism in the uses of ARTs advise extreme caution. They challenge infertility treatment providers and bioethicists to intervene in societal racism and prevent ARTs from reproducing systemic racism while trying to "reproduce" individual persons. Despite the ringing truths and poignant concerns in those critiques, ironically in the Perry-Rogers $v$. Fasano case, each of those claims is inapposite. This case may be the exception to the rule in terms of how the racial dynamics play out, but it is a real case, nonetheless.

First, the Rogerses, the couple who had their embryo mistakenly implanted in another woman, are an African-American couple who clearly had access to ARTs. There is no doubt that ARTs are prohibitively expensive for most couples. ${ }^{194}$ Their expense alone makes them unavailable to many African-American families who are impoverished or of only moderate means because of systemic racism. ${ }^{195}$ The "lack of access

Meaning of Liberty, Chapter 6 (Pantheon Books, 1997); April Cherry, Nurturing in the Service of White Culture, supra note 181; Dorothy E. Roberts, The Genetic Tie, 62 U. CHI. L Rev. 209 (1995); Patricia J. Williams, The Alchemy of Race and Rights: Diary of A LAW Professor (Harvard U. Press, 1991); Patricia J. Williams, Spare Parts, Family Values, Old Children, Cheap, 28 New Eng. L. Rev. 913 (1994); Anita L. Allen, The Black Surrogate Mother, 8 HARV. Black LetTER J. 17 (1991); Lisa C. Ikemoto, Destabilizing Thoughts on Surrogacy Legislation, 28 U.S.F. L. ReV. 633 (1994); Barbara Omolade, Looking Toward the Future: Feminism and Reproductive Technologies, 37 Buffalo L. REv. 203 (1988/89); Beverly Hornsburgh, Jewish Women, Black Women: Guarding Against the Oppression of Surrogacy, 8 BERKELEY WOMEN's L.J. 29 (1993).

194 "In Massachusetts, where infertility care is mandated, the costs, with [ARTs] for a successful pregnancy is $\$ 39,375, \ldots$ other estimates range from $\$ 60,000-\$ 800,000$, per successful pregnancy." Hazel Glenn Beh, Sex, Sexual Pleasure, and Reproduction: Health Insurers Don't Want You to do Those Nasty Things, 13 Wis. Women's L.J. 119, 173, n.362 (1998), cited in, Sherri A. Jason, Comment, "Loving Infertile Couple Seeks Woman Age 1831 to Help Have Baby. \$6,500 Plus Expenses and a Gift": Should We Regulate the Use of Assisted Reproductive Technologies by Older Women?”, 11 Alb. L.J. SCI. \& TECH. 287 (2001). The cost of infertility treatments ranges from $\$ 1,500$ to $\$ 10,000$ per cycle. James B. Roche, After Bragdon v. Abbott: Why Legislation is Still Needed to Mandate Infertility Insurance, 11 B.U. PuB. INT. L.J. 215 (2002) (fn. 95, citing Peter J. Neumann, Should Health Insurance Cover IVF? Issues and Options, 22 J. HeAlth PoL., PoL'Y \& L. 1215, 12168-9 (1997).

195 Laurie Nsiah-Jefferson \& Elaine J. Hall, Reproductive Technology: Perspectives and Implications for Low-Income Women and Women of Color, in Healing Technology: Feminist Perspectives 93 (Kathryn Strother Ratcliff, et. al., eds, Ann Arbor, University of Michigan Press, 1989); Dorothy Roberts, Killing the Black Body, supra note 105, at 
for people of color" critique, while true in most situations for AfricanAmericans who might want to utilize ARTs, particularly given higher infertility rates for African-Americans, ${ }^{196}$ fails to explain the way this case reproduces an underlying societal racism.

Second, the technology was used, in part, because the Rogerses wanted to reproduce hemselves as African-Americans. Nothing about their participation in this ART process indicates that they preferred a white or European-American baby to their own. They engaged in the technology in order to create an African-American child, in the instant case countering the otherwise valid critique that this technology is being used primarily to create white babies in a world where African-American babies are considered less desirable. In addition, while it is clearly arguable that the European-American family may have participated in IVF because they wanted white children rather than children of color, their conduct after the birth belies that conclusion. The Fasanos did not seem to value only white babies, for they were content to claim the African-American child as their own.

Moreover, in response to the third critique mentioned above, the woman treated as a "breeder" in this case was Donna Fasano, a EuropeanAmerican woman, not Deborah Perry-Rogers, an African-American woman. But let there be no mistake that in this case, there was never a design to use one woman for the benefit of another or to pay one woman for her gestating services for the benefit of another. Yet if we are to make any sense of the court's decision denying Donna Fasano visitation rights in the child she bore, we must conclude that the court viewed her solely as a

253-256. For general analyses of the disproportionate lack of wealth among AfricanAmericans, see Dalton Conley, Being Black, Living in the Red: Race, Wealth, and Social Policy in America (U. Cal. Press, 1999); Melvin Oliver \& Thomas Shapiro, Black Wealth/White Wealth: A new Perspective on Racial Inequality (NY: Routledge, 1995).

${ }^{196}$ Raizel Liebler, supra note 184 , reports that Blacks have an infertility rate 1.5 times greater than whites. Id. at fn. 67 and accompanying text (citing a Congressional Office of Technology Assessment report on Infertility from 1988, located at http://www.wws. princeton.edu/cgi-bin/byteserv.prl/ ota/disk2/1988/8822/8822.PDF (visited October 10, 2002)), See also, New York State Task Force on Life and the Law, Assisted Reproductive Technologies: Analysis and Recommendations for Public Policy 11 (1998). 
"breeder" or "incubator." This conclusion reinforces the sex-based or gender-based critique made earlier, but at least for this case, cuts against the usual race-based critique of ARTs.

Last, but not least, the usual race-based critiques of ARTs seem to fail because this is a case where the law permits a couple from a traditionally oppressed racial group to prevail. The Rogerses sought sole custody of "their" African-American child without visitation rights in the white parents, and they won. ${ }^{197}$ Under the particular facts of the PerryRogers v. Fasano case, genetic essentialism yields the unwavering conclusion that the African-American child is the child of the AfricanAmerican parents and should be exclusively in their custody.

As an antiracist strategy in a white supremacist society, if application of a genetics-based analysis works to privilege parents who belong to a subordinated or oppressed race, ${ }^{198}$ shouldn't we argue for its continuation, rather than seeking its rejection? My conclusion is that we should not. The fact that African-American parents won in this case may be an anomaly. Other situations applying a genetic essentialist approach may disadvantage more African-American families or families of color than not. The reasons for choosing or rejecting a genetic essentialist approach cannot be purely situational.

197 This seemingly antiracist result may in fact reflect a more deep-seated, white supremacist view that abhors visions of white women giving birth to black children. As Professor Patricia Williams observed:

Is there not something unseemly, in our society, about the spectacle of a white woman mothering a black child? A white woman giving totally to a black child; a black child totally and demandingly dependent for everything, sustenance itself, from a white woman. The image of a white woman suckling a black child; the image of a black child sucking for its life from the bosom of a white woman.

Patricia Williams, The Alchemy of Race and Rights: Diary of a Law

Professor 226 (Cambridge, MA: Harvard U. Press, 1991).

198 Though the narrative and argument in this essay specifically address Black/White, African-American/European-American racial dynamics, these same concerns arise with Latinos/as, when understood as a racial category, and Asians. See generally, RICHARD Delgado \& Jean Stefancic, eds., Latino/a Condition: A Critical Reader (NY: N.Y.U. Press, 1998); Robert S. Chang, Disoriented: Asian-Americans, LaW and the Nation State (NY: NYU Press, 1999); Frank Wu, Yellow: Race in America Beyond Black AND WHITE (Basic Books, 2001). For a discussion of Latinos/as identity as race-based, see Ian F. Haney Lopez, Race Ethnicity, Erasure: The Salience of Race to LatCrit Theory, 85 Calif. L. Rev. 1143 (1997). 
To reject a genetic essentialist approach because it tends to reproduce a biological racism does not mean, however, that race should not be taken into account in deciding the custody and visitation issues in PerryRogers v. Fasano. In America, in the $21^{\text {st }}$ century, it is still irresponsible and racist to say "regardless of race." ${ }^{199}$ Race in the United States is about power and politics, about social castes and economic classes, about shared histories and cultural practices, about externally imposed stereotypes and exclusions. One cannot ignore these inequalities and injustices in the name of colorblindness. Just as a genetics-based approach tends to produce a biological racism in a race-based society, colorblindness (or ignoring race entirely) tends to reproduce cultural and political racial dominance in a race-based society. In a society borne in racism with slavery as its primary means of production; a society whose founding documents and principles speak of liberty and equality but simultaneously accommodated the persistence of slavery, ${ }^{200}$ a society that fought a bloody civil war in part to attempt to ameliorate the injustices and harms of slavery and then within twenty years sold out its equality aspirations again with the Hayes-Tilden compromise; ${ }^{201}$ a society that required decades of civil rights struggle to guarantee these same citizens and their progeny the rights they should have had from the country's founding and certainly after the Civil War and emancipation; ${ }^{202}$ a society where to this day all the statistical data

\footnotetext{
199 Martin Luther King, Jr.'s dream that people will be judged by the content of their characters rather than the color of their skin is still merely an aspiration for our society. Martin Luther King, Jr., I HAVE A Dream (August 28, 1963). I recognize that if we ever (dare I say, "when we"?) achieve that day when the physiological features of racial identity are as "insignificant as eye color" to one's economic well-being, success, opportunities, and power, then my arguments will need to be changed. I continue to participate in the struggle that would make that so. I anxiously await a time when the arguments in this section are no longer salient and would gladly refine them at that point.

200 Derrick Bell, And We Are Not Saved: The Illusive Quest for Racial Justice (Basic Books, 1987); Derrick Bell, Race, Racism And American Law, $4^{\text {th }}$ ed. (Aspen Law, 2000); Thurgood Marshall, Reflections on the Bicentennial of the United States Constitution, 101 Harv. L. Rev. 1 (1987).

${ }^{201}$ See Eric Foner, Reconstruction: America's Unfinished Revolution 1863-1877, at 575-601 (Harper \& Row 1988).

${ }^{202}$ Howard Ball, A Defiant Life: Thurgood Marshall \& the Persistence of Racism in America (Crown Publishers, 1998); Taylor Branch, Pillar of Fire: America in the
} 
confirm that people of color, and particularly African-Americans, are second class citizens suffering more poverty, unemployment and underemployment and hunger, more of whom live in desperate, unsafe and frequently uninhabitable conditions in inner cities and or rural environments; ${ }^{203}$ in a society where African-Americans are subject to excessive violence, disproportionate imprisonment, police brutality, ${ }^{204}$ and racial profiling, ${ }^{205}$ where African-Americans are significantly

King Years 1963-65 (Simon \& Schuster, 1998); TAYlor Branch, Parting the Waters: AMERICA IN THE KING YeARS 1954-63 (Simon \& Schuster, 1988); JuAN Williams, Eyes oN THE PRIZE: AMERICA's CIVIL RIGHTS YeARS, 1954-1965: A Companion Volume to the PBS Television Series (Viking, 1987); The Eyes on the Prize Civil Rights Reader (Clayborne Carson, David J. Garrow, Gerald Gill, Vincent Harding, \& Darlene Clark Hine, eds, Penguin Books, Blackside, 1991); Richard Kluger, Simple Justice (Vintage Books, 1975); Howard Zinn, A People's History of the United States, 1492-Present: Twentieth ANNIVERSARY EDITION (Harper Collins, 1999).

203 Dalton Conley, Being Black, Lving in the Red, supra note151; Oliver \& Shapiro, supra note 151; ANDREW HACKER, Two NATIONS (NY: Ballantine Books, 1995); Martin Carnoy, Faded Dreams: The Politics of Economics and Race in America (NY: Cambridge U. Press, 1994); National Urban League, The State of Black AMERICA (Washington, DC: National Urban League, January 1992); Dorothy Newman, et. al, Protest, Politics, and Prosperity: Black Americans and White Institutions, 1940-1975 (NY: Pantheon Books, 1978); Manning Marable, How Capitalism Underdeveloped Black America: Problems in Race, Political Economy \& Society (South End Press, 1983); ); See generally, Institute for Research on Poverty, http://www.ssc.wisc.edu/irp/ (and links therein).

${ }^{204}$ David Cole, No Equal Justice: Race and Class in the American Criminal Justice System (NY: The New Press, 1999); Samuel Walker, Cassia Spohn, \& Miriam Delone, The Color of Justice: Race, Ethnicity and Crime in America (Belmont, CA: Wadsworth Pub. Co., 1996); Ronald H. Welch \& Carlos T. Angulo, Justice ON Trial: Racial Disparities in the American Criminal Justice System (Washington, DC: Leadership Conference on Civil Rights / Leadership Conference Education Fund, May 2000); Allen J. Beck \& Paige M. Harrison, Bureau of Justice Statistics, Prisoners IN 2000 (Washington, DC: US Dept. of Justice, August 2001); Federal Bureau of Prisons, Quick Facts, May 2002, http://www.bop.gov/fact0598.html; Angela Y. Davis, Masked Racism: Reflections on the Prison Industrial Complex, ColorLines (Fall 1998), also published at http://home.ican.net/ edtoth/lawprisonrace.html; Angela Y. Davis, Women in Prison: African-American Women have fastest rising incarceration rate in U.S, ESSENCE (Sept. 2000).

205 David A. Harris, Driving White Black: Racial profiling on our Nation's Highways, AN ACLU Special RePORT, June 1999, http://www.aclu.org/profiling/ report/index.html. 
underrepresented as leaders in business, professions and politics; ${ }^{206}$ where most African-American children experience underfunded, inadequate educational opportunities and are tracked into school classes with low expectations of success that lead to dead ends; ${ }^{207}$ a society where African-Americans suffer from inadequate health care and high infant mortality rates; ${ }^{208}$ and where African-Americans are too-frequently portrayed negatively in the media as criminals, thugs and ne'er-do-wells; ${ }^{209}$ in such a society, in this society, we cannot say that race doesn't matter ${ }^{210}$ or issues of race can be ignored. To be colorblind in this situation is to be blind to the realities of the ways racism continues to affect the lives and

${ }^{206}$ Lani Guinier, The Tyranny of the Majority (NY: Free Press, 1994); Thomas Dye, Who's Running America? Institutional Leadership in the United States (Upper Saddle River, NJ: Prentice Hall, 1996); Joint Center for Political and Economic Studies, Black Elected Officials, A Statistical Summary 2000, http://www.jointcenter.org/whatsnew/beo-2002/ (formerly Black Elected Officials: A National Roster)

${ }^{207}$ Gary Orfield, Susan B. Eaton \& the Harvard Project on School Desegregation, Dismantling Desegregation: The Quiet Reversal of Brown v. Board of Education ( NY: The New Press, 1996); Jonathan Kozol, Amazing Grace: The Lives of Children and the Conscience of a Nation (NY: Gown, 1995 ); Jonathan Kozol, Savage Inequalities: Children in America's Schools (Crown, 1991); Jonathan Kozol, Death at An Early Age: The Destruction of the Hearts and Minds of Negro Children in the Boston Public Schools (Boston, MA: Houghton Mifflin, 1967);

${ }^{208}$ Vernellia R. Randall, Racist Health Care: Reforming a Racist Health Care System to Meet the Needs of African-Americans, 3 HeAlth M Atrix 127 (1993); Sidney D. Watson, Race, Ethnicity and Quality of Care: Inequalities and Incentives, 27 AM. J. L. \& MED. 203 (2001); Vernellia R. Randall, Race, Health Care and the law, http://academic.udayton.edu/health/; Unequal Treatment: Confronting Racial and Ethnic Barriers in Health Care (National Academy Press, 2002), available online at http://www.nap.edu/books/030908265X/html/; HHS Initiative to Eliminate Racial and Ethnic Disparities in Health Care, National Vital Statistics System, Linked Birth and Infant Death Data, http://www.cdc.gov/nchs/linked.htm; Infant Mortality Rates by Race and Hispanic Origin of Mother, 1990-1998, at http://raceandhealth.hhs.gov/ 3rdpgBlue/Infant/k2.gif; Office of Minority Health, Data/Statistics, at http://www.omhrc.gov/OMH/sidebar/datastats.htm; Center for Disease Control (CDC)

${ }^{209}$ Robert Entman and Andrew Rojecki, The Black Image in the White Mind: Media And Race in America (U. Chi. Press, 2000); HYPE: Managing the Black Image in the Media, online at http://www.ayaed.com/hype/index.htm.

${ }^{210}$ Cornel West, Race Matters (Beacon Press 1993). 
opportunities of most African-Americans. ${ }^{211}$ Race is not a biological category, but in America, it is a political, socio-economic and cultural one. Until we have eradicated racism from our core, we cannot in good faith allow the law to ignore race, even in the name of the laudable-sounding goal of colorblindness. At this historical juncture an anti-racist strategy must take race into account.

The law has a responsibility to do all it can to make sure that a child whose destiny is in its hand is not reared by racist parents. A passive assumption that there are no relevant race-based factors in deciding issues of child custody and parentage is completely inadequate. No child should be taught that he or she is inferior (or superior) based on racially correlated physical attributes or cultural norms. Children who are likely to be subjected to societal and political racism need parents who can understand and identify this dynamic, and who can teach them their history. Parents of a child subjected to racial prejudices and discrimination must be able to prepare the child to deal with this aspect of life, to nurture the child's selfimage and capacities for success, to offer the child a sense of cultural and racial pride, and to guide the child to live an ethical, responsible life. ${ }^{212}$ While courts cannot intervene in every child's life to assure that the child will not bear a socially-imposed and psychologically-internalized mark of inferiority, ${ }^{213}$ courts can and must act in cases where issues of children's parentage and well-being are before them. Courts are obliged by their

211 Patricia J. Williams, Seeing a Colorblind Future: The Paradox of Race (Noonday Press 1998).

${ }^{212}$ Dorothy Roberts discusses the role that Black parents must play in rearing Black children:

A Black parent's essential contribution to his or her children is not passing down genetic information but sharing lessons needed to survive in a racist society. Black parents transmit to their children their own cultural identity and teach them to defy racist stereotypes and practices, training their children to live in two cultures, both Black and white. Some feel they must cultivate in their children what W.E.B. Du Bois described as a double consciousness; others see their task as preparing their children "to live among white people without becoming white people." Some Black sociologists have opposed transracial adoption on the ground that only Black parents are capable of teaching Black children these necessary "survival skills." (footnotes omitted).

Dorothy RoBerts, KILling the Black Body, supra note 105 at 262.

${ }^{213}$ Charles Lawrence III, The Id, The Ego and Equal Protection: Reckoning with Unconscious Racism, 39 StAN. L. REV. 317 (1987). 
commitments to justice to take the political, social, cultural and ideological implications of race into account in their decision-making.

The debates about transracial adoption may prove informative here. The National Association of Black Social Workers has argued that placing African-American children in European-American families for adoption is a form of racial and cultural imperialism. ${ }^{214}$ They specifically recommend that African-American children be adopted by AfricanAmericans whenever possible. Likewise, in response to a history of U.S. government-backed removal of Native American children from their tribal communities and their placement in European-American families or institutions, the Indian Child Welfare Act requires that decisions about placement of Native American children for adoption be made first and foremost by their tribe with a strong preference for tribal parentage, rather than by state or federal courts with their usual preferences for EuropeanAmerican (or even African-American) families. ${ }^{215}$ Both these approaches respond to the perceived dangers to children of isolating them in families who undermine or sever their cultural identity and racial roots. In response to these concerns, Congress passed the Metzenbaum Multiethnic Placement Act in 1994, allowing race as a permissible consideration in adoption placement. ${ }^{216}$ A strong countermovement in support of transracial adoption and foster care developed, and that provision of the Multiethnic

${ }^{214}$ Roberts, The Genetic Tie, supra note 160, at fn. 98 (citing Position Paper developed at the National Association of Black Social Workers' Conference in Nashville, Tenn., Apr 4-9 1972, reprinted in Rita James Simon \& Howard Alstein, Transracial Adoption (John Wiley, 1977), at 50). See also Twila L. Perry, The Transracial Adoption Controversy: An Analysis of Discourse and Subordination, 21 N.Y.U. ReV. L \& Soc. Change 33 (1993-4).

21525 U.S.C. $\S \S 1901-1964$ (1994). The Act, at $\S 1911$ (a) and (b), states that a tribe shall have exclusive jurisdiction "over child custody proceeding involving an Indian child who resides or is domiciled within the reservation of such tribe" and prefers in cases involving Indian children off the reservation that the state transfer jurisdiction to the tribe. See Barbara Atwood, Identity and Assimilation: Changing Definitions of Tribal Power over Children, 4 MinN. L. REV. 927 (1999). Whether this statutory preference for tribal determinations of child custody is understood to be about sovereignty instead of race, race is still a formidable guiding force in this adoption law.

${ }^{216}$ Howard M. Metzenbaum Multiethnic Placement Act of 1994, Pub. L. No. 103-382, $\$ \S$ 551-554, 108 Stat. 4056, (codified, as amended, at 42 U.S.C. 1996(b) and 42 U.S.C. 5115a (1994)). 
Placement Act was repealed in 1996, clearly prohibiting states and adoption placement agencies from using race, color or national origin as a criteria for foster or adoptive placements. ${ }^{217}$ Some theorists argue that despite the change in the law, race-matching continues to be promoted in the guise of a preference for kinship care. ${ }^{218}$ An extensive debate exists in the literature about whether race-matching in adoption is a good thing. ${ }^{219}$

Those who advocate race-matching would no doubt reject the approach I am promoting in this section. Nonetheless, I believe an approach that assures as much as possible that a child is put into a family environment sensitive to the racial dynamics the child will encounter during his/her life and that the family is determined to nurture the child's cultural

${ }^{217}$ Adoption Promotion and Stability Act of 1996, in the Small Business Job Protection Act of 1996, Pub. L. No. 104-188, 1808(c), 110 Stat. 1755, 1904 (codified as 42 U.S.C. 1996(b) (also referred to as section 1808 of the Small Business Job Protection Act of 1996, entitled "Removal of Barriers to Interethnic Adoption"). This is now a final rule of the U.S. Department of Health and Human Services. Administration on Children, Youth and Families (ACYF), Administration for Children and Families (ACF), and Department of Health and Human Services (DHHS), Final Rule, 65 Fed. Reg. 4020 (March 2000). See also Suzanne Brannen Campbell, Taking Race Out of the Equation: Transracial Adoption in 2000, 53 SMU L. REV. 1599 (2000) for a discussion of the legislative history and considerations.

218 See, e.g., Elizabeth Bartholet, Correspondence, Private Race Preferences in Family Formation, 107 YAle L. J. 2351 (1998) (responding to R. Richard Banks, The Color of Desire: Fulfilling Adoptive Parents' Racial Preferences Through Discriminatory State Action, 108 Yale L. J. 875 (1998)).

219 See Christine M. Metteer, A Law Unto Itself: The Indian Child Welfare Act as Inapplicable and Inappropriate to the Transracial/Race-Matching Adoption Controversy, 38 BRANDEIS L.J. 47 (1999) (outlining the debate and distinguishing race-matching from what occurs under the Indian Child Welfare Act). See generally Symposium on Transracial Adoption, 6 B.U. Pub. INT. L.J. 381 (1997). For examples of writings supporting racematching, see Cynthia G. Hawkins-Leon, The Indian Child Welfare Act and the African American Tribe: Facing the Adoption Crisis, 36 BRANDEIS J. FAM. L. 201 (1997-98); and R. Richard Banks, The Color of Desire: Fulfilling Adoptive Parents' Racial Preference Through Discriminatory State Action, 107 YALE L.J. 875 (1998). For critiques of race-matching, see Katharine Bartlett, Comparing Race and Sex Discrimination in Custody Cases, 28 HofsTRA L.Rev. 877 (2000); Kim Forde-Mazrui, Note, Black Identity and Child Placement: The Best Interests of Black and Biracial Children, 92 M ICH. L. REV. 925, 959-62 (1994); ElIZABETH Bartholet, Nobody's Children: Abuse and Neglect, Foster Drift, and the Adoption Alternative 135-40 (1999) Elizabeth Bartholet, Family Bonds: Adoption AND the Politics of Parenting (1993); and Randall Kennedy, Orphans of Separatism: The Painful Politics of Transracial Adoption, Am. ProsPect, Spring 1994, at 38, 38-42. 
and social connections, goes a long way towards satisfying some of the opposition's concerns.

While some aspects of this adoption debate seem analogous to the issues the court must resolve in Perry-Rogers $v$. Fasano, there is a critical difference. This is not a case where the state or courts are removing a child from his natural parents to place him in the home of a differently raced couple/parent. In this case, Joseph/Akeil was born into the home of differently raced natural parents, but is subsequently claimed by a samerace genetic parent-couple. The court is challenged to determine the custody or visitation rights of the differently-raced natural parent. This is much closer to a traditional custody battle between genetic parents of different races than to transracial adoption. ${ }^{220}$

In a case directly addressing the issue of race in a custody dispute between natural parents, the U.S. Supreme Court in Palmore v. Sidoti in 1984 determined that the state may not take race and race-based societal prejudices into consideration in custody cases. ${ }^{221}$ The European-American ex-husband in Palmore argued for a "race-matching" approach that would award custody of his European-American children to him. He claimed that the reality of social, racist prejudices would negatively impact his children's lives, if they were placed with his European-American ex-wife and her new African-American husband. The Court clearly rejects the exhusband/father's approach. ${ }^{222}$ The Palmore court mandates that the law take a "colorblind" view, despite its recognition that, in fact, race plays a

\footnotetext{
220 See Katharine Bartlett, Comparing Race and Sex Discrimination in Custody Cases, supra note 191, for an extensive discussion of custody battles between differently raced parents (particularly fn. 61) and differently raced adoptive parents and children (particularly fn. 62).

221466 U.S. 429 (1984) ("Public officials sworn to uphold the Constitution may not avoid a constitutional duty by bowing to the hypothetical effects of private racial prejudice that they assume to be both widely and deeply held"), id, at 433. See also J.H.H. v. O'Hara, 878 F.2d 240, 244 ( $8^{\text {th }}$ Cir. 1989) (citing Palmore v. Sidoti for the proposition that "the consideration of race plays no role whatsoever in the regulation of family and domestic relationships").

${ }^{222}$ In Palmore, the genetic parents were both European-American, but after the couple separated, the mother co-habited with and then married an African-American man. The genetic father argued that he should be given custody of the child, in part, because the child would suffer living in a home with parents of different races.
} 
powerful role in the children's lives. Arguably, the Court does not act from colorblindness, but with a vivid recognition of the racial context. The Court acknowledges the societal prejudices and articulates a powerful commitment to overcoming their pernicious effects. The Court concludes that those effects could be overcome better by refusing to succumb to the racial prejudices of the day rather than acceding to them. Despite its rhetoric of color-blindness, the court manifests a profound color consciousness and antiracist sentiment. Palmore makes clear that the court will not tolerate the use of race-based assumptions to interfere with relationships between parents and their children. Unfortunately, this lesson was lost on the Perry-Rogers v. Fasano court.

Perhaps the Fasano court missed the message of Palmore, because the U.S. Supreme Court in that case articulated its reasoning in terms of colorblindness. The Court declares that equality and nondiscrimination, which the Court recognizes as its primary long-term goals, require colorblindness. The law's ideological mating of "colorblindness" with equality and non-discrimination is problematic at this historical moment. ${ }^{223}$ At the dawn of this century, it continues to be

\footnotetext{
${ }^{223}$ For a fascinating symposium in which several articles deal with issues of colorblindness, see Symposium on Law in the Twentieth Century, 88 CAL. L. REV. (2000). E.g., in that volume, Angela Harris writes, "The equation of race law with equality law tends to obscure the law's participation in creating and maintaining racial distinctions, and thus subtly perpetuates the notion that races just naturally are and that equality law simply provides a neutral forum for conflict among them." Angela Harris, Equality Trouble: Sameness and Difference in Twentieth-Century Race Law, 88 CAL. L. REV. 1923, 1927 (2000). Harris argues that whether we are in a century that views "equality as sameness" (colorblindness) or "equality as difference" (color hierarchy), both formulations of equality have been able to coexist in the United States with relations of domination and exclusion. By applying a 'MacKinnonesque' feminist analysis of equality to race law, Harris shows the necessity for a power or dominance analysis of equality, because neither a sameness nor a difference approach to equality has been capable of adequately remedying racial domination and power imbalances. For a sample of MacKinnon's dominance analysis, see CATHARINE A. MacKinnon, Difference and Dominance: On Sex Discrimination, in Feminism Unmodified: Discourses on Life And Law (Harvard U. Press 1987). See also Reva B. Siegel, Discrimination in the Eyes of the Law: How "Color Blindness" Discourse Disrupts and Rationalizes Social Stratification, 88 CALIF. L. REv. 77 (2000) (arguing that race-neutral equality jurisprudence fosters principles of "group-blind distribution without disestablishing group stratification," $i d$., at 84 , and that "color blindness discourse both constrains and legitimates practices that maintain racial stratification," id., at 87. She further suggests that "one needs a concept of social stratification - of status inequality among
} 
particularly inappropriate to omit reflection on the consequences of race stratification and power imbalances on the lives of children when making determinations about their custody and parentage. The law must find ways of taking the reality of race relations into account, while refusing to reinforce disadvantages and harms flowing from racist subordination. That is actually what the Supreme Court did in the Palmore case.

Parents or potential parents in cases of racial differences can be treated equally and non-discriminatorily, even when race is openly considered and even with an understanding that racial factors cut differently for different racial identities. The answer is neither heedless race-matching nor colorblindness, but a careful examination of whether particular parents understand the history and political dynamics of racial groupings in this country and in their communities. If a child is from a subordinated racial group, the parents must evidence a commitment to protect the child from racial domination, while nurturing the child's racial and cultural identity. If a child is a member of the dominant racial grouping, an analysis of parenting abilities should examine the parent's capacity to bring up the child with racial awareness and nonracist values. At a minimum, this inquiry must be included in a "best interests of the child" analysis for custody disputes between differently raced parents or between parents where at least one parent is differently raced from the child. ${ }^{224}$

groups arising out of the interaction of social structure and social meaning - in order to make sense of the blindness trope at the heart of antidiscrimination law" id. at 77-78).

${ }^{224}$ Dean Katharine Bartlett has been a strong critic of the "best interests of the child" standard for custody determinations, because she argues that it is currently too indeterminate and leaves too much to the individual judge's predilections and prejudices.

Bartlett, supra note 191, at 894. She prefers the proposed more determinant ALI standard allocating custody based on pre-divorce proportion of caretaking. Though she concludes that discrimination on the basis of either sex or race should be "categorically prohibited," she also recognizes that an appropriate analysis of the child's best interests may include race-related inquiries such as the one I suggested in the text:

It means no race-matching or sex-matching. It does not mean that a child's need for a healthy self-image, whether it relates to sex or race, cannot be considered. A parent's ability to meet a child's needs for a positive self-image should be relevant to the same extent as other parental abilities. However, nothing should be presumed about a 
Ultimately, a parent's ability to give a child what he or she needs is not based on the parent's genetic contribution to the child's physiognomy, but on the parent's race-consciousness and openness to continued learning in multiracial environments.

A genetic essentialist approach results in unthinking race-matching. Genetic essentialism reinstates a discredited biologic al notion of race that completely ignores social stratification and power imbalances regarding racial classifications. ${ }^{25}$ A genetics-based analysis of legal parenthood, especially when it considers itself race-neutral because it does not take race into account, is a step backwards in our evolving jurisprudence of race. So too is an analysis of parenthood that aggressively refuses to discuss race in a racially charged situation, yet unconsciously applies racebased assumptions about the inappropriateness of interracial intimacy and the biology of race. If our goal is a nonracist jurisprudence, racial dynamics must be carefully examined to make sure that legal decisions are not continuing a pattern of racial domination or stratification. Such an approach that directs courts to investigate the racial awareness and sensitivity of parents denies the Rogerses automatic entitlement to the African-American child because of their racial similarities or genetic link; likewise it would permit the Fasanos custody and visitation despite their racial differences. Both families are on relatively equal footing before a judge who is determining the child's best interests, although the Fasanos admittedly have a greater burden to prove their racial awareness, sensitivity, and cultural consciousness to the child's potential struggles as an African-American in a racially stratified society than do the Rogerses. It is then incumbent upon the court to instruct whichever set of parents prevails under the best interest inquiry about their continuing obligation to deal with racial awareness and sensitivity issues during the child's life.

In most cases involving custody disputes between parties engaged in assisted reproductive technologies, these issues of racial awareness and

parent's ability based on his or her race or sex.

$I d$., at 893. I would argue further that same race, dominant race, or differently raced parents should all be subjected to the same analysis in determining the appropriate placement for a child whose custody is being decided by a court.

225 "[T]he law can become rather muddled when it unthinkingly adopts biological definitions to suit the needs of social distinctions... The result is that biology distorts law and law, in turn, distorts biology.” R. Alta Charo, Biological Determinism in Legal Decision Making: The Parent Trap, 3 Tex. J. of Women \& LAw 265, 266 (1994). 
cultural consciousness will not arise. ${ }^{226}$ When race or ethnicity does become an issue in these cases, however, courts cannot turn a blind eye to the realities of societal racism. Those issues do not disappear through nonacknowledgment. Individual judges may not be particularly well-equipped by experience or their own awareness to evaluate this aspect of a child's best interests or of parental fitness. Courts will necessarily have to rely on the advice of experts in matters of racial dynamics and child-rearing to gather adequate information to make informed judgments about these qualities in the same ways they make informed judgments about other intangible aspects of familial relationships. So long as courts are empowered to make best interests determinations for children when potential adult caregivers are disputing their custody, questions about racial awareness and nonracist values ought to be included in that judgment. Defaulting to solely genetics-based definitions of parenthood or a simplified race-matching approach risks perpetuating patterns of racial inequality and domination.

\section{Conclusion}

ART mistakes force the egal system to examine its underlying assumptions about genes, sex, race, and legal parenthood. While questions about race, sex and genes have always existed in families, as the PerryRogers v. Fasano case illustrates, those questions may be writ large in disputes arising from ART fiascos. Cases about embryo mix-ups, particularly cases involving couples and children of different races, are valuable heuristic models to test our juridical conceptions of legal parenthood. The complicated issues arising from ART mistakes force us to work even harder to discover the underlying assumptions in our legal

\footnotetext{
${ }^{226}$ A compelling argument can be made that issues of racial sensitivity and awareness should be addressed in all ART mix-up cases where courts are deciding the "best interests" of a child or the appropriateness of particular parents having custody, whether all the parties, including the children, are European-American or not. I realize that the likelihood of persuading a court to utilize this analysis in an ART mix-up case where all parents and children are identified as being of the same race is negligible, so I will not pursue this argument in the text right now. I am persuaded, however, that the argument is sound and should be developed.
} 
notions of kinship and to ask ourselves about the values we want reflected in our applications of law in the future. The turn of the new millennium combined with the increasing use of complex reproductive technologies present a perfect opportunity for us to discard the biases that have tainted our understandings of reproduction and law in the past. As our science and technologies grow more sophisticated, so should our insights about equality and human relationships. When we think about how the law ought to deal with these previously unimagined reproductive consequences of ART mistakes, we need to think about how racism and sexism continue to distort our legal understandings in the present and how we must prevent that from happening in the future.

An increasing number of courts today believe that the science of genetics provides the solution to the legal problems that the science of ARTs has wrought. In Perry-Rogers v. Fasano the court ultimately relied on genetics, despite its claims to the contrary, to determine who the rightful parents were of the child born from the mixed-up embryo. When courts define parenthood genetically, they revive harmful sex-bias. A geneticsbased approach to determining legal parenthood reincorporates a male-bias in law by valuing all of men's biological contributions to reproduction (gametes), but valuing only a small part of women's biological contributions to reproduction (gametes, but not gestation, labor or birth). When courts make a genetic-based judgment about parenthood in the context of differently raced couples, their biases are compounded. When courts assume that similar physical traits of racial group membership describe legal and biological parent-child relationships, they risk reinstating a biological racism, with its imprudent biological race-matching and damaging assumptions about the illegitimacy of interracial intimacies/families. Finally, courts perpetuate race-based injustices and prejudices by pretending to ignore issues of race while our society and cultures are still steeped in racial inequalities and oppression. Race as social, political, cultural and ideological practices, not as biological fact, must be considered relevant when ART mistakes involve people with racial differences. As the court's inadequate decision in Perry-Rogers $v$. Fasano reveals, failure to examine these underlying race and gender assumptions and biases ends up making the devastation of ART mistakes worse, not better.

Society cannot expect to use technologies, including ARTs, without mistakes. Whether negligent, reckless or intentional, mistakes with their unplanned consequences are inevitable. We are only human, and humans are fallible, no matter how sophisticated our technologies become. In the realm of bioethics, the law consistently finds itself in the awkward position 
of having to resolve the contests caused by the consequences of these alltoo-human mistakes with the technologies. Although traditional tort monetary damages actions against the profit-making marketers of these technologies may serve important societal justice goals, they do not resolve who will be the legal parents of the child. Mistakes with assisted reproductive technologies involve the creation of new life and disputes that go to the heart of questions of identity and family. As citizens and members of our communities we must urge our legislative bodies to engage in constant study of the ever-changing implications of these new reproductive technologies on family relationships and to make appropriate revisions to out-dated statutes and regulations. Unfortunately, courts often need to resolve these cases without much legislative guidance, while the public policy, ethical, and legal debates are still raging. None of these are easy questions with simple right answers. Courts are bound to get the analysis wrong in some cases. They are more likely than ever to get it wrong when they try to find quick technical or scientific answers to complex human, familial cultural and social problems. As lawyers and bioethicists we must help courts resolve these dilemmas properly by challenging their faulty analogies, offering more appropriate analogies, situating the bioethical debates within the larger political and social critiques of systemic gender, race and class biases, steering courts away from solutions rooted solely in our current sciences, and reminding courts that we can only move forward with open, well-reasoned discussions of the issues and our values. 